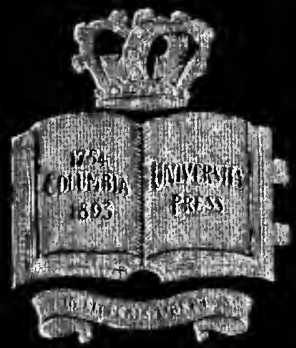

rnia

al 


\section{LIBRARY}

UNIVERSITY OF

CALIFORNIA

SAN DIEGO 


$$
\frac{A r}{2^{2-r}}
$$




\section{Digitized by the Internet Archive in 2007 with funding from Microsoft Corporation}




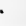



1 



\author{
Colnmbia deribersitg \\ STUDIES IN COMPARATIVE LITERATURE
}

\title{
IDYLLS OF FISHERMEN
}




\section{COLUMBIA}

\section{UNIVERSITY PRESS}

\section{SALES AGENTS}

NEW YORK :

LEMCKE \& BUECHNER

30-32 West 27Th STREET

LONDON :

HENRY FROWDE

Amen Corner, E.C.

TORONTO :

HENRY FROWDE

25 Richmond StreEt, W 


\title{
IDYLLS OF FISHERMEN
}

A HISTORY OF THE LITERARY SPECIES

\author{
BY \\ HENRY MARION HALL, Ph.D.
}

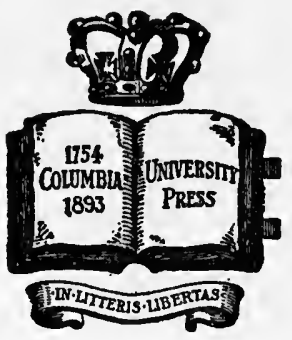

Nebo York

THE COLUMBIA UNIVERSITY PRESS

I9I2

All rights reserved 
Copyright, I9I2

By The Columbia University Pres

Printed from type March, 1912 
THIS monograph has been approved by the Department of English and Comparative Literature in Columbia University as a contribution to knowledge worthy of publication.

\section{A. H. THORNDIKE,}

Secretary. 

TO MY MOTHER

FLORENCE HOWE HALL

THIS BOOK IS AFFECTIONATELY DEDICATED 



\section{PREFACE}

Many of the works in foreign languages cited in this book are familiar to scholars, but as the plan of the work has been to render all quotations in English, for the convenience of readers a list of translations easily accessible in libraries has been embodied in the Bibliography. 



\section{CONTENTS}

Chapter Page

I. Origins of the Pastoral of Fishers I The origin of the English idyll of fishermen in ancient Greek literature and the development of the pastoral of fishers in Greek and in classical Latin.

II. Sannazaro and His Imitators on the Continent ............. 45

The immediate source of the fisher idyll of the Renaissance in the "piscatory eclogues" of Sannazaro, and the development of the species in the pastoral literature of Italy, Spain and France.

III. The English Fisher Idylls ...... 96

The idyll of fishermen in England from the earliest times to the final decay of the "new style" of pastoral in the eighteenth century.

Appendix ................... I99

BiblograpHy ................ 201

Chronological List of the Chief EngLish Piscatories ............ 212 InDEX $\ldots \ldots \ldots \ldots \ldots \ldots \ldots \ldots \ldots \ldots \ldots$ 



\section{IDYLLS OF FISHERMEN}

\section{CHAPTER I}

Origins of the Pastoral of Fishers

The origin of English fisher idylls, or "piscatory eclogues," is to be found in the poetry of ancient Greece, just as is that of shepherd song. In a land of islets, sounds, and promontories, many a youth drove his flock afield on hillsides whence he could look down on the blue shield of the sea, rimmed with white surf, seething and thundering on rock-ribbed coasts, or tumbling in lines of breakers along curving reaches of yellow sand. Amid the waste of dunes a spot here and there marked the hut of a fisher, while not far away the solitary owners might be seen, tugging at the oars or hauling their nets. When these men in the fishing skiffs paused for a moment in their labor and glanced towards the uplands, they saw the white of sheep, dots on green pastures, or heard perhaps the faint and distant music of the pastoral pipes. By very necessity the herdsman and the fisher were near neighbors, so it is only natural that they should appear in verse as companion figures. Thus there existed in the beginning of country song an obvious relationship between poetry dealing with rustics and that concerned with fishermen. 
This relationship was obviously determined by the accident of neighborhood, but limited by the essential differences between the verdant fields sacred to Pan and those barren, desolate expanses owning the sway of Neptune. The gray of the sea dims most ancient pictures of fishing life, and in them, as a rule, we may look in vain for the sunny warmth of Sicilian meadows where shepherds pipe and sing. It is noteworthy also that the mood of piscatory poetry is usually serious or melancholy, and in keeping with the surroundings. Even legends about the deities of fishers share this quality. Proteus is almost an incarnation of the swift and awful changes of the ocean, a lonely prophet voice of many waters. So it is also with the stories of Arion cast overboard by the sailors, of Ceyx and Halcyone, of Circe's frightful revenge on Scylla, and of many more.

The essential difference between these two varieties of verse is well illustrated in their beginnings. As soon as rustic song became literature poets selected for their themes activities which they deemed typical, but which at the same time appeared appropriate for poetical expressionsuch, for instance, as the pasturing of herds rather than the cleansing of folds or pens. The things thus consciously chosen tended in time to become fixed as pastoral conventions. Such selection with the resultant growth of conventions characterizes also the work of those who describe fishers. The men may fish, talk, sing or dream, but the sordid details of their lives, the scaling 
or cleaning of fish and the like are purposely omitted. The earliest sketches show these toilers of the sea to be men of great age, dogged patience, bitter poverty, yet of contentment with their lot, and these characteristics after a while become generally associated with the piscatory poem.

These limitations and these conventions show that the work embodying them deserves to be classed as pastoral, in spite of the consideration that the barren aspects of the life described lend to early pieces about fishermen an appearance of realism perhaps greater than that in related poetry concerning shepherds. The body of ancient literature thus dealing with the neighbors of the shepherd is not great, but it develops along parallel lines with bucolics, and will be found affected by nearly every change incident to pastoral evolution. The shepherds' "Golden Age," however, was never considered a happy, care-free time for fishermen. It is worth noting, too, that whereas it was believed that Apollo had once come down on earth to live as a shepherd, the only corresponding fisher myth is that of Glaucus, who was regarded as singularly lucky in that he was transformed into an ocean deity, and so escaped from an existence of toil and misery.

Theocritus (c. 280 B. C.) is the creator of the literary piscatory, as he is of the literary bucolic, and the main object of this essay is to trace the development of the class of poems, with related pieces of prose, which are in a general way descended from his fisher idyll. For such a study 
a brief account of the beginnings of the genre in earlier Greek forms the logical introduction, since fishermen are described by Homer, and figure in epigrams, mimes and plays of great antiquity. It is necessary, however, to omit examination of miscellaneous material relating rather to fish-lore than to the pursuits of men. Much of this is to be found in Athenaeus' "Deipnosophists," a sort of philosophers' feast, in which the qualities of everything edible are discussed, with quotations about fish from plays, histories, treatises and various other kinds of literature. To this extraordinary work we owe the preservation of many fragments of the earliest mimes, but unfortunately the interest of Athenaeus in food gives a one-sided view to all his citations.

The history of the fisher eclogue may be conveniently divided into three parts, the first of which includes consideration of the extant matter in Greek and in classical Latin. After this preliminary survey comes the work of the humanist Sannazaro (ante I503), who initiated the modern variety. He contrived a variant on the manner of Virgil's pastorals, shifting the scene from Arcadia to the seashore, changing herdsmen into fishers, and introducing relevant material from Theocritus. These pieces were extensively imitated in Italy, both in Latin and in the vernacular, and the resultant body of poetry constitutes a recognized literary species, closely related to contemporary bucolics. A discussion of these marine pastorals will be followed by an account of the spread of the fisher motive to other literary 
forms, such as the sonnet, the romance, and the drama. Finally, this second division of the treatise must deal with the wider dissemination of the Sannazarian "ecloga piscatoria," evidenced by imitations in France and in Spain. The introduction of the form into Elizabethan England, with the story of the growth of the English fisher idyll, forms the subject treated in the last portion of the present work.

The earliest pictures of country life extant in Greek are found in Homer's Iliad. On the mighty shield of Achilles ${ }^{1}$ the God of Fire wrought in tin, and brass, and gold, the shapes of shepherds playing on their pipes as they drive their flocks to water, where warriors lie in wait to seize them; of broad pastures in a pleasant glade, all white with browsing sheep; of cottages, stalls and wattled folds, and of herdsmen grazing their kine by a murmuring river. Still more elaborate are gravings of a great vineyard in busy vintage time, of vast fallows where plows are drawn by plodding cattle, and of a broad field of wheat through which the harvesters mow their way, while sheave-binders bind the sheaves, servants prepare feast and sacrifice, and maids knead meal for the hungry reapers.

Homer's fishermen are not drawn in such detail, but the fact that they appear here and there in epic similes is sufficient reminder of the familiarity of the ancients with the hard life of those who wrung a scant living from the ocean. The

${ }^{1}$ Bryant's translation, Book 18, 541-606. 
poet says, for instance, that Patroclus in battle looked: ${ }^{2}$

..." as when an angler sits

Upon a jutting rock, and from the sea

Draws a huge fish with line and gleaming hook,

So did Patroclus, with his shining spear,

Draw forth the panting Trojan from his car

And shook him clear: he fell to earth and died."

Another illustration occurs in the Odyssey, where Scylla seizes the companions of Ulysses:

"As when an angler on a jutting rock

Sits with his taper rod, and casts his bait

To snare the smaller fish, he sends the horn

Of a wild bull that guards his line afar

Into the water, and jerks out a fish,

And throws it gasping shoreward, so were they

Uplifted gasping to the rocks. ..."

Such glimpses in the Homeric poems give the same picture of solitude, poverty, and patient labor, and contrast sharply with the other scenes from humble life.

"The Shield of Heracles," a heroic poem formerly attributed to Hesiod, but now conceded to be by a later poet, presents in more ornate and florid style the same kind of pictures as those which appear on the buckler described in the Iliad. Just as in Homer's poem the sea encircles the entire shield, but it is described at some length, with flights of screaming swans that "skimmed the breasted surge," while in the waves "fishes

2 Bryant, 16, $510-515$.

Bryant, I 2, 300-306. 
were tossing in tumultuous leaps." In another place :

"... there appeared

A sheltering haven from the untamed rage Of ocean. It was wrought of tin refined, And rounded by the chisel; and it seemed Like to the dashing wave; and in the midst Full many dolphins chased the fry, and show'd As though they swam the waters, to and fro Darting tumultuous. Two of silver scale Panting above the wave, the fishes mute Gorged, that beneath them shook their quivering fins

In brass. But on the crag a fisher sate Observant: in his grasp he held a net Like one that, poising, rises to the throw."

The poem is very obviously an imitation of Homer, and it seems likely that the poet borrowed his picture of the fisher from the older epic. Yet this marine view, with the haven and the cliff is not, as in the Homeric work, chance illustration, but is a careful elaboration of a suitable background for the solitary figure, just as the fields in the ancient pastoral form an artistic setting for the laborers. It is by far the most complete illustration from fisher life extant before Theocritus.

From these and other fragments preserved by Athenaeus it is safe to assume that much chance illustration drawn from the activities of fishers has been lost. The occasional occurrence of early fisher epigrams, too, with the marked similarity

-Tr. C. A. Elton, 422-9, 283-95. 
between these and the more numerous group known to be the work of later imitators, suggests the possibility that a considerable number may have been composed. The most ancient are the following, the first of which has been attributed to Sappho, ${ }^{5}$ and the second to Alcaeus :

"Meniscus, mourning for his only son, The toil-experienced fisher, Pelagon, Has placed upon his tomb a net and oar, The badges of a painful life and poor."

\section{"The Poor Fisherman."}

"The fisher Diotinus had at sea

And shore the same abode of poverty, His trusty boat-and when his days were spent, Therein self-rowed, to ruthless Dis he went; For that which did through life his woes beguile, Supplied the old man with a funeral pile."

Now let us compare a typical bucolic epigram by Theocritus, "For a Herdsman's Offering":

"Daphnis, the white-limbed Daphnis, that pipes on his fair flute the pastoral strains, offered to Pan these gifts-his pierced reed-pipes, his crook, a javelin keen, a fawn-skin, and the scrip wherein he was wont on a time to carry the apples of Love."

Meniscus and Diotinus are aged, lonely, and miserably poor. They are not "white-limbed," nor do they play the flute nor "carry the apples of Love." They are like all the other fishermen in ancient Greek, whether we read of them in epi-

${ }^{8}$ Tr. T. Fawkes, Epigram I.

"E. W. Peter, "The Poets and Poetry of the Ancients." 
grams, in Aesop (560 B. C.?), or in fragments of lost treatises.

The relationship between primitive shepherd song and the worship of rustic gods finds its analogue in the connection between fishermen and the worship of marine divinities. In many cities offerings of fish, or even of eels, smoked on altars in the temples. Apollo, whom countrymen honored as "Mouse-killer," was worshipped among the Eleans under the title of "Fish-eater," and in the fane of his sister goddess Diana at Pisa, there was once a picture in which Neptune was represented as bringing a tunny to Jupiter in labor. In another city the seasonal advent of tunnies was celebrated by a religious festival called the "Thunnaeum," in which fishermen sacrificed to the sea-king the first fish caught. Mullets were highly regarded for their edible qualities, for being destroyers of the poisonous " sea-hare," and as being sacred to Hecate, one of the trinity to which Artemis belonged. For these reasons they were always carried about during the celebration of the Artemisia. Hecate was herself sometimes regarded as a sea-goddess. At Corinth, the city between two seas, festivals in honor of Neptune led to the production of dithyrambic choruses sung by celebrants dancing round an altar. One piece, attributed to Arion, is a hymn addressed to the ocean king, with shoals of nereids and fish swarming around him in the waves.

The conception of sacred and mysterious fish was very ancient and appears first in the myths about Glaucus, once a fisherman of the "Golden 
Age." According to the usual version of the story he one day caught in his net a large number of fine fish. These he landed, and admired their beauty as they lay gasping on the turf. All at once they nibbled the herbage, became filled with fresh life, and swam down the bank over the beach to the water. The astonished Glaucus plucked some of the strange grass and tasted it. Instantly he was transformed into a sea-god, with green hair and a scaly tail, and plunged into the waves among the escaped prey. He remained in the ocean, and became endowed with powers of prophecy. At a later time he fell in love with the nymph Scylla, whom Circe, out of jealousy, changed into a sea-monster. Many slightly different versions of this story were rendered in verse or prose in very early times, and at a later period furnished subject matter for several laments.

One other legend about a fisherman of the Golden Age is given in a fragment of the lost poem by Pancrates the Arcadian, "Works of the Sea." The poet cites the superstition common among seamen that the pompilus (nautilus) was a sacred fish, and tells a story to illustrate it. Epopeus, an aged fisher on the island of Icarus during the Golden Age, once threatened to punish this fish. He was angling with his son one day, and they had ill luck, landing nothing but pompili. This had happened before, so he and his son in a rage ate every one of their catch. Not long afterwards a whale attacked their boat and devoured the old man in the presence of his son. 
Before leaving for the present this matter of the sacred fish, it is worth noting that according to one story Apollo learned prophecy from Glaucus. It is said, too, that near a certain grove sacred to the sun-god people used to consult the fish for oracles. It was necessary for the questioner to provide two wooden spits with meat on them and to cast these into a certain eddy. $\mathrm{Nu}$ merous "finny herds," including the "prophetic grayling" and small whales came to the bait, while a prophet observed them. His declaration varied with the size and number of the mysterious swimmers. Much floating material of this sort connected with stories of sea-gods, nereids, and metamorphosis, doubtless familiar from very early times, was eventually embodied in various treatises, which contain more " unnatural natural history" than reliable data.

From fragments of ancient plays it is evident that fishers were always among the familiar characters on the stage, and that they were sometimes protagonists. They figured in the earliest comedies about which anything is known, those by Epicharmus (490 B. C.) founder of the "Old" or "Dorian" comedy in Sicily. Some of these pieces parodied mythology, while others held the mirror up to everyday life. He was the first playwright to ridicule the greedy parasite, and the characters which he drew became stock personages in later drama. More lines remain from his burlesque "Hebe's Marriage" and from "The Muses," a recast of the same work, than from any others. The Muses are not the traditional 
ones, but daughters of river-gods whose streams abound in fish. Apparently they masquerade as fishermen, perhaps as a chorus, equipped with rods and nets, eager to capture food for the wedding feast. The Sea King joins them:

"Neptune then arrives himself

Laden with most beauteous nets

In the boats of fair Phoenicia,

Then we all do spari catch

And scari too, that sacred fish

Whose very dung may not be thrown away."

His brother Jupiter shows great voracity, and seizes most of the prizes caught, keeping some for himself, but presenting others to Juno. Similar broad extravagance characterizes "The Muses," but the band of fishermen bears a more important part in the action. It seems likely, also, that fishers were drawn with realistic touches in several plays on everyday life by Epicharmus. We can form no definite conclusions from the mere bits of dialogue, but in such pieces as "Land and Sea," fishermen and countrymen probably figured in burlesque by contrast of manners.

From Epicharmus Sophron apparently inherited the stock figures for his Sicilian mimes, but he is thought to have characterized them with more subtile humor. Each piece was a single scene, and "The Clown and the Fisherman" may have presented in compact form, the same situation as did the earlier "Land and Sea." Little, however, is left of either play besides descriptions of fish and remarks on their habits. In another of Sophron's mimes, "The Tunny Catcher," the 
characters were an aged fisher and his son "Cothonias," a name said by Athenaeus to have been suggested by the "cothon," a fish that loves to bathe in mud. The single vestige remains a puzzle :

"But if your stomach happens to have swallowed a shrimp."

To reconstruct these interludes is, of course, im. possible, but it is considered probable that they resembled, in witty, realistic parry and thrust of dialogue, the pieces by a successor, Herondas, eight of which have recently been recovered. It is safe to assume, too, that fishers were commonly presented in mimes. The influence of Sophron on the poems of Theocritus is thought to have been considerable, and it should be noted that the conversation in pieces like "The Tunny Catcher" may well have formed precedent for that in the Theocritean idyll about the two old fishermen.

Before turning to that poem it may be well to add a word about the piscatory element in other plays. Plato may have ridiculed the legend of Sappho's vain love for the Lesbian fisherman in his comedy of "Phaon," and he seems to have introduced fishers also in his "Europa" and "Holidays." Antiphanis, a prolific playwright of "Middle Comedy," produced a drama entitled "The Female Fisher," of which more is known than of any other play of the class under consideration. The most considerable fragment runs as follows: 
"Give me some cuttle-fish. O Hercules!

They've dirtied every place with ink; here, take them

And throw them back again into the sea,

To wash them clean: or else they'll say, O Dorion, That you have caught some rotten cuttle-fish:

And put this cray-fish back beside the sprats. He's a fine fish, by Jove. O mighty Jove, $O$ you Callimedon, who now will eat you?

No one who's not prepared to pay his share. I've giv'n you your place here on the right, You mullets, food for great Callisthenes; Who eats his patrimony in one dish, Next comes the mighty conger from Sinope, With his stout spines: the first who comes shall have

For Misgolas has no great love for such. But here's a citharus, and if he sees him He never will keep off his hands from him;

For he, indeed, does secretly adhere As close as wax to all the harp-players. I ought to send this best of fish, this tench, Still all alive and leaping in the dish, To the fair Pythionica, he's so fine:

But still she will not taste him, as her heart Is wholly set on cured fish,-here I place These thin anchovies and this dainty turtle Apart for Theano, to counterbalance her."

Apparently the speaker (the "Female Fisher") and Dorion are taking their catch from a boat to display it on a stall for sale. In citing these lines Athenaeus remarks :

"And it is a very clever way in which Antiphanis thus jested upon Misgolas, as devoting all his attention to beautiful harp-players and 
lyre-players," adding that Pythionica is spoken of as fond of cured fish because she had for lovers the sons of Chaerephilus, the seller of salt fish.

The humor in this play is much like that in the mimes by Herondas, and the lines extant give a clue to the probable nature of fisher drama. Here again, however, the interest of Athenaeus in food leads to his citing a long list of fish. He speaks enthusiastically about a dialogue concerning the actual pursuits of fishermen in a play by Antiphanis called "The Shrimp," but instead of quoting it he gives a large number of passages concerning the greed of fish-mongers. In one place, to be sure, he pictures the death of some fishermen in a storm, but only to show the resultant rise in the price of sea-food at the city stalls. From other bits it appears that Archippus' "The Fishes and the Athenians" satirized various people under the names of fish spelled in the same way as their own, and a vase-painting representing men astride dolphins is thought to have been suggested by this comedy. A lost play by a contemporary, Diphylus, is believed to have been imitated in the Roman Plautus' "Rudens," with its idyllic pictures of fishing life.

From these older plays fishermen were taken into "New Comedy," notably into the work of the great Menander. In the "Carthaginian" a fisher says :

"I offered Boreas much frankincense

And yet I did not catch one single fish, so I must Now cook lentils for my supper." 
A few lines from "Purple" ("The Purple Fish?") also mention actual fishing:

"But I, as being a skillful fisherman, Have carefully devised all sorts of arts To catch those vile paguri, enemies To all the gods and all the little fishes. And shall I not without delay beguile An old buglossus? That would be well done."

Menander" gave the title "The Fisherman" to another drama in which characters of various sorts besides fishers were introduced. Thus we find the speeches of a band of exiles from Heraclea, who give a ridiculous description of Dionysus, the gluttonous tyrant of their city. Other lines, possibly spoken by merchants, enumerate various articles of merchandise brought to port by a ship. The only mention of the sea is this:

"And the disturbed and muddy sea which breeds The largest tunnies."

Theocritus must have known many works in which fishers were described, but he needed no suggestion for the composition of his idyll about the fisherman's dream beyond the tender reminiscence with which he looked back on the scenes of his youth in Sicily. We see the waves sparkling beneath the moon when the poet makes forsaken Simaetha cry:

"Lo, silent is the deep, and silent the winds, but never silent the torment in my breast."

${ }^{1}$ Pollux (Onomastic. 50, ro, c. I2) cites Menander's play by name, and says that in it a fisher came upon the stage equipped for fishing. 
In the song of Lycidas the sea is as bright as the singer's mood, and as calm:

"The halcyons will lull the waves, and lull the deep, and the east, that stirs the sea-weed on the farthest shores, the halcyons that are dearest to the green-haired mermaids of all the birds that take their prey from the salt sea."

The miserable cyclops Polyphemus:

"sat by the sea-weed of the beach from the dawning of day," or he would sing to his cruel love . . . "sitting on the crest of the tall cliff, and looking to the deep," and beseech her to "leave the gray sea to roll against the land."

In another place the giant's dog:

"barks as he looks into the brine, and now the beautiful waves that softly plash reveal him as he runs upon the shore."

In another scene Menalcas, meeting Daphnis on a pasture overlooking the ocean, says:

"Nay, but beneath this rock will I sing, with thee in mine arms, and watch our flocks feeding together, and before us the Sicilian sea."

The Argo's crew, coming to an island, "landed on the deep seashore and a sea-bank sheltered from the wind, they strewed their beds, and their hands were busy with firewood."

Even in his familiar comparisons Theocritus thinks of the sea:

"it is as light labour to count the waves upon the beach, as many as wind and gray-sea tide roll upon 
the shore ... as to win favour from a man that is smitten with the greed of gain."

Fishermen were as familiar to the Sicilian poet as the waters by which they lived, and we catch glimpses of them in several of the idylls besides the one in which they are the only personages. A love-sick goatherd, singing in vain before the cave of Amaryllis, turns suddenly towards the cliffs, uttering this threat:

"I will cast off my coat of skins, and into yonder waves will I spring, where the fisher Olpis watches for the tunny shoals, and even if I die not, surely thy pleasure will have been done."

Elsewhere a reward for singing is mentioned thus :

"To the other I gave a goodly spiral shell, the meat that filled it once I had eaten after stalking the fish on the Icarian rocks (I cut it into five shares for five of us), and Menalcas blew a blast on the shell."

This is a reminder that shepherds ${ }^{6 \mathrm{a}}$ occasionally went fishing, as they are mentioned as doing in most famous pastorals of later times. The most graphic description of a fisher in the bucolic pieces is one of the carvings on an ivy bowl. The designs present contrasting pictures of primitive life, of the same sort as those graven on the heroic shields - two swains trying to win the favor of a pretty maiden, and:

"beyond these an ancient fisherman and a rock are fashioned, a rugged rock, whereon with might

${ }^{\text {Bn }}$ It is interesting to note that Theocritus speaks of himself as the fisherman who secured the spiral shell. 
and main the old man drags a net for his cast, as one that labours stoutly. Thou wouldst say that he is fishing with all the might of his limbs, so big the sinews swell all about his neck, grey-haired though he be, but his strength is as the strength of youth. Now divided but a little space from the seaworn old man is a vine-yard."

It has been thought that the picture of the old man is imitated from the one already cited from "The Shield of Heracles," and it is likely that Theocritus is here softening the Homeric buckler motive to suit idyllic life. At any rate one sees at a glance that these fishermen differ in no respect from those mentioned in more ancient writings, but we think of them as old, patient, halfstarved through dint of toil by day or night, " seaworn." Their horny hands can better grasp a trident than hold the delicate pastoral reeds. They play no tunes, they dance no dances, and they sing no songs, unless perhaps some rowing chant, as they tug at the oars when homeward bound.

The twenty-first idyll gives a more studied, elaborate portrayal of their hard lot:

"Tis Poverty alone, Diophantus, that awakens the arts; Poverty, the very teacher of labour. Nay, not even sleep is permitted, by weary cares, to men that live by toil, and if, for a little while, one close his eyes in the night, cares throng about him and suddenly disquiet his slumber.

Two fishers, on a time, two old men, together lay and slept-they had strown the dry sea-moss for a bed in their wattled cabin, and there they lay against the leafy wall. Beside them were strewn the in- 
struments of their toilsome hands, the fishing creels the rods of reed, the hooks, the sails, bedraggled with sea-spoil, the lines, the weels, the lobster pots woven of rushes, the seines, two oars, and an old coble upon props. Beneath their heads was a scanty matting, their clothes, their sailor's caps. Here was all their toil, here all their wealth. The threshold had never a door, nor a watch-dog; all things, all, to them seemed superfluity, for Poverty was their sentinel. They had no neighbor by them, but ever against their narrow cabin floated up the sea.

The chariot of the moon had not yet reached the mid-point of her course, but their familiar toil awakened the fishermen; from their eyelids they cast out slumber, and roused their souls with speech.

Asphalion. They lie all, my friend, who say that the nights wane short in summer, when Zeus brings the long days. Already have I seen ten thousand dreams and the dawn is not yet. Am I wrong, what ails them, the nights are surely long?

The Friend. Asphalion, thou blamest the beautiful summer. It is not that the season hath wilfully passed his natural course, but care, breaking thy sleep, makes night seem long to thee.

Asphalion. Didst ever learn to interpret dreams? for good dreams have I beheld. I would not leave thee to go without thy share in my vision; even as we go shares in the fish we catch, so share all my dreams. Sure, thou art not to be surpassed in wisdom; and he is the best interpreter of dreams that hath wisdom for his teacher. Moreover, we have time to idle in, for what could a man find to do lying on a leafy bed beside the waves and slumbering not? Nay the ass is among the thorns, the lantern in the town hall, for, they say, it is always sleepless. 
The Friend. Tell me then, the vision of the night; nay tell all to thy friend.

Asphalion. As I was sleeping late, amid the labours of the salt sea (and truly not too well-fed, for we supped early if thou dost remember, and did not overtax our bellies), I saw myself busy on a rock, and there I sat and watched the fishes, and kept spinning the bait with the rods. And one of the fish nibbled, a fat one, for in sleep dogs dream of bread, and of fish dream I. Well he was tightly hooked, and the blood was running, and the rod I grasped was bent with the struggle. So with both hands I strained and had a sore tussle for the monster. How was I ever to land so big a fish with hooks all too slim? Then just to remind him he was hooked, I gently pricked him, pricked, and slackened, and as he did not run, I took in line. My toil was ended with the sight of my prize; I drew up a monstrous fish, lo you a fish all plated thick with gold! Then fear took hold of me lest he might be some fish beloved of Posidon, or perchance some jewel of the sea-grey Amphitrite. Gently I unhooked him, lest ever the hooks should retain some of the gold of his mouth. Then I dragged him on shore with the ropes, and swore that never again would I set foot on sea, but abide on land, and lord it over the gold.

This was what wakened me, but for the rest, set thy mind to it, my friend, for I am in dismay about the oath I swore.

The Friend. Nay, never fear, thou art no more sworn than thou hast found the golden fish of thy vision; dreams are but lies. But if thou wilt search these waters, wide awake, and not asleep, there is some hope in thy slumbers; seek the fish of flesh. lest thou die of famine with all thy dreams of gold!" 
The authenticity of this piece has been called in question, ${ }^{7}$ but it possesses the subtile charm of a picture drawn from life, and is worthy of comparison with any other Theocritean poems which paint sunnier phases of idyllic existence. It is, moreover, only an elaborate rendering of the same sort of illustration that has been cited from bucolic idylls, and forms with these shorter glimpses of fishermen, precedent for a long line of piscatory pastorals by later writers. Throughout the existence of the species, too, occasional eclogues were composed with a view to reproducing the realistic effects that characterize the story of Asphalion and his friend. This realism, with the fact that the two characters are suffciently different as to afford the necessary dramatic contrast, and that they chat, but do not sing, has been called evidence of mimic origin. That some little play may have embodied a similar story of credulity in a miraculous dream is likely enough, but the descriptive side of the idyll in its present form and the distinctly serious, moralizing tone are foreign to the mime.

Asphalion's fear that his catch might be sacred to some sea-god is born of the same superstition to which reference has already been made. It might be added that a poet whom Theocritus probably knew at Alexandria, Callimachus, calls the "chrysophrys" sacred in his "Galatea":

"Or shall I rather say the gold-browed fish That sacred fish. ..."

'R. J. Cholmeley, "The Idylls of Theocritus Edited with Introd. and Notes." 
In his epigrams the same writer says the perch is loved by the gods, while a fragment by Theocritus, part of a panegyric on Berenice, mother of his patron, Ptolemy Philadelphus, mentions a silver fish:

"And if any man that hath his livelihood from the salt sea, and whose nets serve him for ploughs, prays for wealth, and luck in fishing, let him sacrifice at midnight, to this goddess, the sacred fish that men call 'silver-white,' for that it is brightest of sheen of all,-then let the fisher set his nets, and he shall draw them full from the sea."

Most of these allusions to sacred fish may be explained by very ancient legends. ${ }^{7 a}$ Thus the dolphins were loved by Neptune because they helped him to find Amphitrite, when she had fled from him. Again, the nautilus was once a sailor but had been transformed by Apollo, who had become furious with him because he had taken on his ship Ocyrhoe, a girl whom the god loved. In like manner, all the other sacred fish might be explained by folk-lore.

The Greek poems most closely related to the Theocritean fisher idyll are certain epigrams by a younger contemporary, Leonidas of Tarentum, who is thought to have known Theocritus on the island of Cos. His three fisher epigrams resemble the idyll in vocabulary and in several other important particulars. The first one introduces the fisher Diophantus, by which name Theocritus addresses the friend for whom he composed his piscatory poem:

7a Cf. the fisher in The Arabian Nights, Book I. His songs are prayers like those in Greek epigram. 
"A well curved anchor, and long spears, a fishing line of horse-hair, large baskets for holding fish, with a weel cunningly wrought for the finny prey, impliments of fishers who roam the sea, a rugged trident, spear of Posidon, and a pair of oars from light fishing-skiffs-all these the fisherman Diophantus set up to the king of his craft, as custom is, the relics of his ancient calling."

The list of implements is very much the same as that given of the paraphernalia in the cabin of Asphalion, and is enumerated in about the same order. A similar list and a wattled cabin are found in the second fisher epigram:

"Theris the aged fisherman, whose skill

Taught him to live and many a basket fill

With fishes, (for their plundering foe was he, And than the sea-fowl oftener tost at sea,) Theris, whose few-oared boat, and seine, and hooks,

Could win the fishes from their secret nooks, Yet,- not Arcturus, nor the blasts that blow Down-rushing, swept this aged man below: But, like a lamp long burning, and whose light Flickers, self-spent, and is extinguished quite, In a rush hut he died:- to him this grave (No wife no child, he had) his brother fishers gave."

The third of this group 8 pictures a more violent death, and may be paraphrased as follows:

"Parmis the far-famed fisher, best reaper of the ocean strand, master of all the wiles of labrus, scarus and the bold bait-snapping perch, with all the

${ }^{8}$ A. Pal. VI. 4 ; VII. 295 ; VII. 504. 
caves and rocks at the bottom of the sea, as he caught his prey by the reefs of the dark blue deep, grew sad, and pined and prayed for death from the waves. Then destruction darted upon him in a whirl-wind, striking him on the neck, while lines and rod, and anchors were whirled away, for the thread of his life was spun, and a fisherman heaped this mound for the dead."

The realism in these poems and the elaborate detailed treatment mark them as belonging to the same class as the Theocritean idyll of the two old fishers, while occasional extant examples of later imitations indicate that many such pieces were undoubtedly composed. The conventions of all are essentially the same, and show that the fisher epigram constituted a class by itself.

Bion and Moschus, more famous disciples of Theocritus, wrote no fisher poem. Bion's only picture of the ocean is a fragment of an idyll imitated probably from Theocritus' complaint of Polyphemus to Galatea, while the studied prettiness of a description by Moschus, of Europa crossing the deep on the bull's back marks it as the illustration of a mythological "genre-picture." Such productions were typical of the artificial side of Alexandrian letters, and are said in some cases to have been inspired by wall-paintings. ${ }^{9}$ In marked contrast with such marines stands a single poem in which Moschus pictures the life of fishers.

'At Herculaneum is a wall painting of fishers. Philostratus the Rhetorician describes a painting representing a lively fishing scene. We even find an old fisher seated on a rock with a rod in hand stamped on a coin from old Crateia. 
"When the wind on the grey salt sea blows softly, then my weary spirits rise, and the land no longer pleases me, and far more doth the calm allure me. But when the hoary deep is roaring, and the sea is broken up into foam, and the waves rage high, then lift I mine eyes unto the earth, and the trees, and fly the sea, and the land is welcome, and the shady wood well pleasing in my sight, where even if the wind blow high, the pine tree sings her song. Surely an evil life leads the fisherman, whose home is his ship and his labours are in the sea, and fishes thereof are his wandering spoil. Nay, sweet to me is sleep beneath the broad-leaved plane-tree; let me love to listen to the murmur of the brook hard by, soothing, not troubling, the husbandman with its sound."

The poet is repelled by the wilder aspects of the ocean, and he thinks with a shudder how hard is the lot of fishermen compared with that of the farmer, who need not fear the storm. Moschus knew no more about fishing than he did about raising sheep, and his glimpse of marine life is as far removed from that pictured by Theocritus as his bucolics are different in spirit from those by his great predecessor.

More characteristic of the Alexandrian period are epigrams speaking prettily of Venus in her character of wave-born goddess, of nautilus spreading tiny sails to the wind, and the like. ${ }^{\text {a }}$ Even the poems on Glaucus share the artificiality of other mythological pieces, if we may judge from fragments such as this by the poetess Hedyle : ${ }^{10}$

9a See epigrams of Callimachus.

${ }^{10}$ Athenaeus, VII. 
"Bearing a gift of love, a mazy shell,

Fresh from the Erythrean rock, and with it too The offspring, yet unfledged, of Alcyon,

To win the obdurate maid. He gave in vain.

Even the lone Siren on the neighboring isle

Pitied the lover's tears. For as it chanced,

He swam towards the shore which she did haunt, Nigh to th' unquiet caves of Aetna."

Glaucus here comes to the cave of his beloved Scylla, proffers gifts, and being rebuffed, utters a complaint. The poem is thus a chance antecedent of fisher laments in eclogues by the humanists. Hedyle's son, Hedylus, is said to have written a similar piece, in which the fisher Glaucus strove to woo the nymph Melicerta, but being rejected, leaped into the waves and became a god. All these stories belong to the literature of metamorphosis, rather than to that of the fisher pastoral, and find their most familiar expression in Ovid.

Between the days of Theocritus and those of Sannazaro fisher eclogues do not seem to have been composed, but the motive appears here and there in other forms of literature with which the famous humanist may well have been more or less familiar. Of these the epistles of Alciphron (I8o A. D. ?) affect to be intimate correspondence between the stock characters of the mime-parasites, courtesans, shepherds, fishers, flirtatious wives and the rest. The letters give tantalizing glimpses of unfinished romance, so that when we read them we see as in a kaleidoscope, the shifting, many-colored life in decadent Athens. 
Whether or not of actual mimic origin, they picture what was always to be seen on the stage, and in the mimes.

It is therefore reasonable to suppose that the fisher letters may help us to understand the probable nature of the mime of fisher-folk. This seems the more plausible because the epistles from fishermen fall naturally into two groups, one of which presents matters akin to those in the recovered mimes, while the other group is perhaps more closely related to the Theocritean idyll. To the first class belong the missives dealing with the motives of love or jealousy. One fisherman writes to his wife, praising sea life as more desirable than that ashore, after which he upbraids her for sneaking away so often to Bacchanalian revels at Athens. A companion piece is a furious note to a fisher from his spouse, accusing him of flirting with a young courtesan, and threatening to return to her father's care. One young fellow, having met ill luck, asks his sweetheart whether he had not better join a crew of prosperous pirates. Another youth warns his comrade against wasting money on a singing-girl, but receives a flippant reply, scorning the good counsel, and declaring passionate love for the damsel. Again, a fisher-maiden writes to tell her mother that she is so desperately in love with a handsome pilot that she must marry him or leap from the rocks of Piraeus, as Sappho did from the Leucadian cliffs. Her mother sends an irate answer, saying that the girl " needs a dose of hell-bore," and that if her father hears of the nonsense he will throw 
her to the fishes. The stories thus glanced at are obviously like those represented in plays, and are the earliest pieces extant in which fishers are represented as being in love, another reason for assuming that the epistles are of mimic suggestion.

Besides these a few other letters, notable for satirizing conditions in the city should be classed with the mimic epistles. In one a fisher urges a notorious parasite to use his influence to bring him rich customers, and accuses officers of the market of extorting blackmail. Another expresses fear of impressment in the Athenian navy, because the city is preparing for war. A very lively missive describes a crowd of effeminate youths with frisky dancing-girls, whom a fisherman is hired to take for a sail, and from whom he receives handsome pay. The last of this lot attacks usurers. A fisher has pawned his skiff for money with which to have his seines repaired, but the loan-shark duns him until he is forced to sell a gold chain which he is having made for his wife.

The second group of epistles has to do with the actual purstiits of fishers, and here Alciphron borrowed hints from Theocritus, just as he did in his shepherd and vintage pictures. Presumably he knew the city better than the country. In one letter a fisherman tells how he, with several companions, storm-bound for three days on a desolate shore, took refuge in a miserable cabin. Weary and hungry they kept from freezing by a drift-wood fire, but after the tempest they ventured out in a crazy skiff, and caught such numbers of fish that the corks of their net were pulled 
under. Selling the largest of their booty, they had small fry left sufficient for their wives and children. The gray coast, the hut, the old boat, the fishing tackle, the fact that the men are old, the hunger and misery are all very much as we have seen them in Theocritus. None of the remaining letters shows such striking resemblances with the idyll, but all tell of poverty and hardship. One man complains of a bad master who makes him fish all day and all night; another writes to his wife to propose giving up his laborious craft and training their children to become husbandmen; another accuses a rich fisher of luring away his assistants by high wages, and another commends a recent exchange of gifts-a sea-sparrow, mullets and thirty-five purple fish for a pair of oars. Three epistles concern a tattered net which a surly old fellow has abandoned, but which he refuses to give to a poor acquaintance. A humorous note relates that a fisher, whose business it is to report the presence of fish to others, finds a place where the water is dark with tunnies. Fishers cast a great net, but draw up-only a rotting camel. The last letter of this group describes an approaching storm, and recommends an attempt to bury the bodies that will be washed ashore along the Sicilian beaches.

In the letters about actual fishing occasional descriptive touches recall the idyllic life as we see it in the poems of Theocritus, and such indebtedness as these suggest seems the more probable because Alciphron's style is usually rather terse and plain. The shepherd epistles and those by 
fishers alike retain many of the pastoral conventions, and even the amoebean construction is not entirely lost in sequences of short notes, consisting of questions and answers. It is possibly a fair criticism to say that the letters combine in prose, elements of mimic origin with elements due to the influence of the earlier pastoral.

In Greek later than the work of Alciphron but few compositions have any intimate connection with the Theocritean pastoral of fishers, though the conventions emphasized by Leonidas linger on in later epigrams. Amid sea pictures the gods of fishermen chat confidentially in Lucian's "Dialogues of the Sea Gods," but only to give witty expression to the author's skepticism towards mythology. Their imitations of earlier poets and their amoebean form give them a place beside the eclogue, and the dialogues may be said to form connecting links between the mythological idyll and the humanistic eclogue of marine mythology, often considered as one species by Italian poets. Lucian's play, "The Fisherman," has no relationship with the mimes or idylls, but takes its title from a scene in which the poet sits on a parapet of the Acropolis, equipped with the rod of a Piraean fisherman. His bait of gold and figs attracts a swarm of brilliantly colored fish, which he catches: "Salmo Cynicus," "Flat Sole Plateship," and other philosophers clad in scales.

Bearing somewhat the same relationship to eclogues of fishermen that Virgil's Georgics do to those of shepherds, were the Greek verse treatises on fish and fishing. No fewer than six 
didactic epics of the sort were composed, but only that by Oppian (2II-2I7 A. D.) is extant in complete form. It is written in hexameter, and combines material based on observation with much extraordinary fish-lore gathered from floating material. In the last part of the treatise the accounts given of the methods of capturing fish by men on various coasts lend a few pictures akin to independent idylls. Most of the poem, however, is like Pliny's Natural History put into verse. The poems as a whole have little relationship with the piscatory eclogue other than that implied in the fact that they are written in verse and tell much about the practices of fishers.

More important are the later Greek epigrams, mention of which has already been made, and a few examples of which will serve to show how little these pieces differ from their ancient models. The first is by Maecius Quintus, of Smyrna ( 380 A. D.?), an epic poet:

"To thee Priapus, that dost delight in the sunken reefs, worn down by the waves of Nessis on the sea-coast, and in the overhanging cliffs, has Paris, the fisherman, hung up a crab, with its oyster-like shell, killed by the cleverly catching rod; the flesh he roasted over a fire and happily crunched with his teeth, half-eaten by age, but the shell has he given to thee. Wherefore do thou give him, not abundance, but the power to successfully catch with his fishing-line fish to quiet the pangs of hunger.

Another is by the "Prefect of Egypt":

"The aged Cinyras, on ceasing to labour, has offered up to the nymphs these nets worn by the con-. 
tinued catching of fish. For no longer was he able, with a trembling hand to cast the circular busom of the open net. If there be the offering of a small present, this, ye nymphs, is no blame (to me); since the whole life of Cinyras is this."

One by Serapion of Alexandria was suggested by a bone:

"This is the bone of a hardworking man. Surely thou wert either a seafaring trafficker, or a fisherman in a blind wave. Say to mortals, that, while we are urging onwards to other hopes, on such a hope as this are we broken up."

The last two that will be cited were written as late as the middle ( 540 A. D.?) of the sixth cen"tury, under Justinian. The first is by Paulus "Silentuarius," or the "privy counselor," who sent epigrams from the court at Constantinople to the author of the second, Agathias, anthologist and historian, who used to send in reply epigrams from his country house on the Bosphorus:

"The old Amyntichus bound a net with lead at its extremity round a trident, after ceasing from his toils in the sea, and said to the deity, while shedding tears from his eye-lids, like the swell of the sea- "Thou knowest, O blessed power, that I am past work. But limb-wasting poverty, from which there is no escape, is young even at the threshold of old age. Nourish still the gasping old man, but from the land, as thou choosest, $O$ ruler of the land and sea."

The quotation from Agathias is the only fisher epigram to use a love motive: 
"A fisherman was employed in catching fish. Him did a damsel of property see, and was affected in her heart with desire, and made him the partner of her bed. But he, after a life of poverty, took on himself the swell of all kinds of high bearing. And Fortune with a smile was standing by, and said to Venus,- "This is not your contest, but mine."11

Some of the poems just cited may have been composed a thousand years after those first quoted in this book, yet in them we find emphasized the same old conventions, and the last fishermen in ancient Greek poetry are like the first, aged, seaworn, poor and patient. This is just what might be expected, because real fishers differed little from age to age, and it was not until the times of later humanism that new conventions were contrived for idylls in which they figured.

A passage by Nonnus (fifth century A. D.) in that extraordinary hexameter poem of mythology, the "Dionysiaca," depicts with much vigor a set of companion figures like those carved on the shield of Achilles, or perhaps like those of some mural painting. Bacchus, on his way to the land of Cadmus, is represented as gazing with admiration on Tyre and the sea-shore near by. Side by side he sees the neatherd and the goatherd, with their grazing beasts; he listens with delight to the shrill music of the pastoral pipes and to the songs and shouts of fishermen, busy by their skiffs or dragging nets to land. In one place a dryad's voice sounds from an oak in a wood that

${ }^{11}$ The Greek Anthology as selected for the use of Westminster, Eton and other public schools. Also Edwards' selection, 776, 784, 556, 797. Eton, 70 . 
overhangs the surf, and below a nereid is wantoning. Ceres speaks to Neptune, herds bellow, sailors talk with wood-cutters, and the rattle of rigging mingles with the murmur of forest leaves. (Dion. 40, 327-336.)

Fishers appear also in the romances, the last prose in which the genius of ancient Greece shines conspicuously. In the famous pastoral "Daphnis and Chloe," 11 for instance, a picture of fishermen is prettily introduced, and in a manner to illustrate the old contrast between the idyllic life of shepherds and that of their neighbors, the fisher folk. Daphnis sat with Chloe on a hill near the sea :

"While they were at their meal, which, however, consisted more of kisses than of food, a fishing boat was seen proceeding along the coast. There was no wind stirring; a perfect calm prevailed; so having taken to their oars the crew were rowing vigorously, their object being to carry some newlycaught fish to a rich man in the city. They dipped their oars, doing what sailors usually do to beguile their toil. The boatswain sung a sea-song, and the rest joined in chorus at stated intervals. When they were in the open sea, the sound was lost, their voices being dispersed into the air, but when running under a headland they came into any hollow and crescent shaped bay, the sound became much louder, and the song of the boatswain was distinctly heard on shore. A deep valley here sloped down from the plain above, which received into it the sound, as into an instrument of music, and repeated with the most perfect imitation every note which was uttered. There could be heard the distinction between the

${ }^{11 a}$ By Longus. 
dash of the oars, and the voices of the sailors; and a very pleasing sound it was; beginning on the sea, the duration of its echo upon shore was proportioned to its greater lateness in commencing.

Daphnis, understanding the nature of the echo, turned his attention solely to the sea, and was delighted with viewing the boat as it glided by the shore quicker than a bird could fly. At the same time he endeavored to store up some of these strains in his memory, that he might play them on his pipe. Chloe, who had never, till now, heard what is called an echo, turned first to the sea and listened to the boatmen, as they sang, and then looked round to the woods. ...."

In another romance, "The Loves of Clitophon and Leucippe," by Achilles Tatius, ${ }^{13}$ a crew of purple fishers in their boat figure in one of the many adventures with pirates so characteristic of these stories.

More significant than such chance illustration is a passage in the "Ethiopian History of Theagenes and Chariclea," 14 by Heliodorus. This is a considerable interlude about fisher-folk introduced as a complement to analogous bucolic interludes, and carefully elaborated into a picture of quiet life contrasting sharply with the wild and disconnected episodes that precede and follow it. The narrator, Calasiris, tells how his ship anchored near Zacynthus after a stormy and perilous voyage. Rowing ashore he trudged along the beach until he came upon a hut before which sat an

${ }^{12}$ Bk. 3, pp. 5o. Tr., Bohn's Libraries.

${ }^{13} \mathrm{Bk} .5$, pp. 44I. Bohn's Lib.

${ }^{14}$ Bk. 5, pp. I38-142. Tr. Bohn's Libraries. 
aged fisher, mending a tattered seine. An amusing dialogue ensued, the traveler asking several times for lodging, and the old man replying that the net was torn on a promontory while his son had charge of their fishing boat. Seeing at length that the fellow was deaf, Creon shouted his question in his ear and this time was understood. Tyrrhenus, for so the deaf man was called, received Calasiris and his two wards into his cabin, where for some days they lived happily with the fisherman's family, all eating at one rude table and going fishing with the host, who proved, of course, a master-hand at the craft.

At length one day Tyrrhenus took his guest to a remote bay, where after swearing by Neptune and all the sea-gods that he loved him well, he disclosed the fact that a pirate was then holding his vessel in hiding behind a nearby cape, and sending out spies every little while to learn when the voyagers would set sail. Tyrrhenus had sold them fish and had thus learned their plan to seize the beautiful Chariclea. Thus warned, Calasiris embarked on another ship, in which he escaped by night.

The ghost of Ulysses having appeared to Calasiris in a dream, and reproached him for not sacrificing to him, as guardian spirit of those coasts, the fisherman now hurried to make propitiatory offerings on the rocks by the sea, and thus assisted, the fugitives were enabled to reach Crete in safety.

This prose idyll, complete in itself, is the most elaborate picture of the kind in ancient Greek. 
The influence of Theocritus is strongly suggested by imagery incidental to description of the cabin, the tackle, and the boat, as well as by the delineation of the character of Tyrrhenus, aged, seaworn, superstitious, wretchedly poor, yet content with his lot, and hospitable to the stranger. Thus in these comparatively late romances we again find the fisher and the shepherd both living the idyllic life. Moreover, the sort of existence led by Tyrrhenus bears the same relationship to that led by Daphnis and Chloe as the Homeric fishers do to Homeric swains, and it has been pointed out that this relationship apparently remains identical wherever the two motives occur in the same literary form, whether in comedies, mimes, epigrams, epistles or romances. It should be added that although so much of ancient Greek poetry has been lost, the relationship under discussion, together with the relative importance of the fisher and of the swain in pastoral, is shown clearly enough by the extant pieces which have already been mentioned.

It has been shown that piscatory conventions originated and became fixed in the same manner as did those in bucolic poems. The fisher idyll about the marvelous dream was perhaps inspired by the poet's reminiscent sense of contrast between a highly complex city life and that along the desolate sea-shore, just as the bucolics spring from an analogous sense of difference between the same complex existence and that of sunny Sicily. Obviously, too, the contrast between the occasional fishermen whom Theocritus introduces 
and his herdsmen or shepherds, is only that inevitable on a broad canvas painted from life. The minute detail with which the poet enumerates the implements and tackle in Asphalion's hut, or follows each step in the playing of the mysterious fish, is the result of actual observation. Had Virgil imitated this realistic idyll ${ }^{15}$ any number of imitators might have essayed composing similar pieces, but as it was, the modern fisher eclogue originated in a blending of Theocritean with Virgilian concepts and conventions, which enjoyed a certain vogue among the humanists of the sixteenth century in Italy.

\section{The Fisher in Classical Latin}

Descriptions of fishermen are found in Roman adaptations of Greek dramas and elsewhere, but the extant examples have little connection with one another, and would hardly merit citing but for the importance in the eyes of the humanists of precedent in classical Latin. In a play by Plautus (254-I84 B. C.) "Rudens," or "The Shipwreck," thought to be a Latin rendering of some lost work of the Greek Diphylus, two slaves go fishing at night (Act 4, scene 3), and one of them pulls up a wallet in his net. This night scene with the garrulous chatter of the poor fishermen about the ownership of the strange catch, may have been suggested by the story of

${ }^{25}$ Moretum, a realistic account of a poor man making a salad (sometimes attributed to Virgil), resembles the fisher idyll in some respects. A similar Pseudo-Virgilian piece is "Copa." 
Asphalion. This is made more likely by another passage in which Plautus introduces a band of fishermen tramping along the beach towards the temple of Venus (Act 2, scene I), chatting as they go. One describes their experiences, telling of their struggles with nets or rods in freezing water-" this is all their sport-this all their exercise." Their days and nights are spent in trapping lobsters and crabs, or in tearing oysters from the rocks. Many a day they must go home empty-handed, "soused and pickled," so that life on the rough sea is a sorry, hopeless affair at best. Unless they secure fish they must go supperless. Talking thus they enter the sacred fane in order to perform sacrifice to the goddess, that they may secure her favor and so have good luck in fishing. Trachalio, meeting them there, calls them (Act 2, scene 2), "seathieves," and a "starved generation." Striking verbal resemblances make it likely that the playwright imitated this interlude from the picture of fishing life given by Theocritus in his twentyfirst idyll. A similar illustration occurs in Seneca's "Hercules Furens," where ${ }^{16}$ a chorus of Thebans describes dawn, with the commencement of the labors of man, and the sounds of animals and birds. They speak of the shepherd, of the mariner setting sail, and then:

"Then another man, a fisherman resting on the wave-indented rock, is engaged either in baiting afresh his unsuccessful hook, or, all anxiety, beholds in mental prospect the reward of his patience already grasped in his right hand."

${ }^{10}$ Act I., I 54-I 58. 
In Latin mimes fishermen were characters, as in the Greek. Decimus Laberius, for instance, wrote one called, presumably from the principal character, "Piscator." This is said to have been one of many imitations of Sophron, but unfortunately the Latin fragments are as few in number as the Greek. Of another play by Laberius, "The Crab," there remains but part of one line. The longer remnants of two fisher farces, "The Fishermen," and "The Sea-shell," by the comic poet Pomponius Bononiens are almost as unsatisfactory.

Turning now to poetry, we find that Virgil does not even mention fishermen in his pastorals. His only allusions to fishers are a few lines in his first "Georgic," 17 incidental to an account of the primitive arts of man, and an account of the fisher Menaetes, in the Aeneid. The first of these passages pictures one man dragging his net through a broad stream, another putting out into the deep sea with seines, and a third busy with hook and line. Menaetes is one of the victims to the fury of Turnus in battle. The youth had gone into the war unwillingly, preferring his quiet life on the shores of Lake Lerna, where he had lived in a humble cabin. The neighboring waters supplied him with plenty of fish, so that he remained content, happily ignorant of the ways of the grasping rich, for his father was very poor, and hired the land which he tilled. The lines about this unfortunate fisherman were probably ${ }^{17}$ L. I 42 fol. 
imitated by Ovid (Met. 3, 582-59I). Pentheus of Thebes, furious at Bacchus, whom he wishes to destroy, demands the god's name and receives this reply:

"My name, said he, is Acaetes, my country Maeonia: my parents of humble stock. My father left me no fields for rough bullocks to cultivate, nor any wool-bearing flocks, nor any herds. He too, was poor; and it was his practice with a rod of reed, and line and hook, to catch the leaping fish. When he gave up the pursuit, he said to me, "Receive the wealth I own, and cling to it, successor to my endeavors," and dying, he left me naught except the waters-this alone may I call my patrimony."

Mention has been made of the story of Glaucus in Greek literature. A fragment on this myth ${ }^{18}$ has been attributed to Aeschylus (by Athenaeus, Strabo, and Pausanias) and longer passages are extant from poems by Alexander of Aetolia and by others. Of the Romans Cicero is said by Plutarch to have composed a poem on the fisherman Glaucus, but by far the best picture of the sort is to be found in Ovid's Glaucus and Scylla, ${ }^{18 a}$ some lines of which are probably reminiscent of the Greek fisher idylls.

Another isolated example of the same sort is given in Lucan's" "Pharsalia" (V. 5II-560).

${ }^{18}$ Met. I3, 921-955. To Ovid, too, has often been attributed an incomplete verse treatise on fishing, the "Halieutica."

18a Fragments of two pieces about Glaucus are attributed to Aeschylus. One may be part of a marine satyr drama.

${ }^{19} \mathrm{~A}$ poem on the war between Carsar and Pompey. Lucan died $65 \mathrm{~A}$. $\mathrm{D}$. 
A dialogue between Caesar and an old fisher is notable as giving a minute description of an old cabin, the boat, and other equipment evidently taken from Theocritus, and deliberately sketched as background for the conversation. The passage thus constitutes a piscatory idyll inserted in a longer work.

The only fisher poem of any length in classical Latin is the "Mosella," one of the "idyllia" of Ausonius ( 387 A. D.?), a piece in hexameter, and 843 lines long. Vivid pictures of the scenery along the banks of the river Mosella (Meuse) are followed by the enumeration and characterization of all the fish that swam its waters, rendered after the manner of the didactic epic. A considerable portion of the piece is devoted to a very lively description of the fishermen of the Meuse, made from actual observation. There are men in boats dragging nets in midstream, men watching the corks of little nets in shallower water, men perched on the banks or on rocks, armed with rods of cane, watching the floats bobbing on the water, or jerking in the prey. One boy has the ill fortune to lose the largest of his catch, which manages to flap its way back into the river, whereupon he leaps in after it, "like Glaucus," trying to recapture it by swimming. This poem was a favorite with the Englishman, Izaak Walton, who quotes from it in "The Compleat Angler," and it was among the pieces which Sannazaro, the first of the humanist writers of fisher eclogues, is known to have studied. If it had any influence on the piscatory pastoral, 
however, it was limited to the furnishing of fisher lore, and that was always to be found in Pliny.

From such quotations as have been given thus far, it may readily be seen that the fisher poems extant in ancient Greek and Latin are not of sufficient importance to be classed as a distinct literary species. They constitute merely a special branch of the pastoral, which failed to attain any considerable proportions during classical times, and which humanists of the early renaissance ignored, just as Virgil had done. It remained for a later poet, Giacopo Sannazaro, to take advantage of the neglect into which the fisher convention had fallen, and to compose in the learned tongue the first set of what he called "piscatory eclogues." 


\section{CHAPTER II}

\section{Sannazaro and His Imitators on the Continent}

Sannazaro, or as his fellow humanists called him, Actius Sincerus, was born of parents of Spanish descent at Naples in 1458. For some years he lived with his mother in San Cipriano, whence he returned to his native city while still a youth. He fell in love with the beautiful Carmosina Bonifacia, but proved almost as shy and unsuccessful a lover as had Dante, and finally in despair wandered away into France. When he came back Carmosina had died. His bitter grief found expression in the last pages of his famous pastoral romance, and also in the Latin eclogues which he composed at a later date. He soon became a distinguished member of the "Academia Pontana," a society of scholars who met at the house of his friend Pontano. Some of his Latin verses gained favor for him at the court of Frederick of Aragon, with whom he went into exile in France. He returned to Naples in 1503 , after the death of his lord, and seems to have then lived at the home of Cassandra Marchesia, his friend and platonic love.

It is likely that some of the fisher eclogues were among his early productions. The Arcadia is thought to have been composed in its original form when the poet was only twenty-three, and 
Sannazaro himself alludes to it as his first work, adding that the piscatories were written not long afterwards, and with the same youthful zeal:

"Nor less did my enthusiasm drive me, too, among the band of fishermen to cast my lines in the watery bays and to enclose in empty lobster-pots deceptive bait, and to tempt with the hook the herds that wander through the waves, since I was the first to go down to the salt waves, daring to render in words sounds yet untried."

Having made this claim to the invention of fisher verse, he mentions his elegies, epigrams, wars and exile as of later date. Finally, that he had completed at least some of the eclogues before leaving his country is made plain by some lines in " $\mathrm{De}$ Hortis Hesperidum,"2 a poem by his friend Pontano. The learned humanist laments the exile of Sannazaro and alludes to his fame as the author of piscatory idylls.

That Sannazaro should have composed these pastorals of the seashore is not extraordinary. He was very fond of his Villa Mergellina, perched on cliffs overlooking the Bay of Naples, and could watch fishermen at any time, as they drew their nets and sang their songs. Within sight of the blue Mediterranean, too, he first met Carmosina, and walked with her along the shores, so it is not unnatural that he should make her a fisher girl in his eclogues, and himself a fisherman. Like a true humanist, however, he disregarded the native madrigals of the coast, turning for his models

${ }^{1}$ Bk. 3, elegy 2, 53-582.

2 Bk. 2. 
to Theocritus and Virgil. The Greek idylls furnished him occasional illustration, but his greater indebtedness to the Mantuan is so obvious that an early biographer says of it:

"Never did he turn his eyes from the greatness of Vergil, whom he admired so much that every year in solemn feast with his friends he celebrated the birthday of the great Roman."

This adoration of Virgil accounts for the general plan of the fisher eclogues, which was to imitate the famous bucolics in marine coloring, if I may use the term. Hence in the humanist's poems Arcadian pastures rise into the bold outline of the fairest coast in the world, the usual inland quiet is troubled by the murmur of tides, or by the tramp of surf along sounding beaches, while the melody of the lark or of the nightingale is changed to the hoarse cries of divers or of halcyons. By a similar analogy swains are transformed into fishermen, and rustic gods into ocean gods. In place of Pan, guardian of flocks and herds, father of country song, we find dark-green Proteus, shepherd of the sea-calves, skilled in song and prophecy. The "Carpathian wizard's hook" is wielded to prod throngs of drowsy seals, while in his webby clutch the reed pipe becomes a conch, the deep notes of which are echoed "by scaly Triton's winding shell." The oracles of Apollo yield to "old sooth-saying Glaucus' spell," every nymph turns nereid, and all the other divinities of the land become the corresponding divinities of the sea.

Such protean metamorphosis is not only applied to the general conception of the piscatory ec- 
logues, each of which is the marine equivalent for some one of Virgil's, but extends to the entire detail and imagery. A few examples will make this clear. In his lament for Daphnis ${ }^{3}$ Virgil pictures grief so general that no cattle would drink or eat, while woody hills reëchoed the sounds of mourning until even Libyan lions roared in sympathy. Sannazaro says ${ }^{4}$ that sorrow for the death of the fisher girl Phyllis was so great that no dolphin would leap or play, and that rocky shores rang with the sympathetic plaints of ravens, coots, and gulls. The sorrow of the nymphs and Apollo for the dead shepherd finds a counterpart in the fisher's appeal to the nereids and Glaucus. Lycidas longs to have Glaucus "give him some of his magic grass" that he may become a sea-god and so leave the hated land. Even Virgil's deification of Daphnis as guardian of shepherds is imitated in the deification of Phyllis :

"But thou, whether thou dwellest happy in heaven above or now among the Elysian shades and the awful bands of Lethe dost follow fish through the stagnant streams; or dost gather eternal flowers in thy beautiful hand-narcissus, and crocus, and longlived amaranth, and dost mingle delicate seaweed with pale violet, look upon us and come propitious. Henceforth shalt thou ever be guardian spirit of the waters ever friendly to fishermen."

${ }^{3}$ Ec. V.

4 Ec. I.

"Mr. J. H. Hanford ("The Pastoral Elegy and Milton's Lycidas"-Mod. Lang. Assn. of Am., Sept., r9ro) shows that Milton probably imitated this passage in the lines where the singing shepherd bids the spirit of Lycidas "look homeward" and later when he invokes Lycidas as "Genius of the shore." 
Again, the shepherds build altars to Daphnis and Apollo, but the fishers raise them to Phyllis and the sea-gods, while the bucolic offerings-cups of milk with bowls of oil, are replaced in Sannazaro's poem by "garlands of oysters" with shaggy "sea-calves." Lastly, Virgil's Menalcas praises his friend's song as "sweet as rest beneath the shadow of trees," or as "quenching one's thirst at a crystal brook," whereas the fisher compliments the strains of Lycidas as "sweeter than the lamentations of halcyon, or than the complaints of swans, heard in the grass beside sweet streams."

In spite of the closeness of this parallel, Sannazaro rejects in some details the example of Virgil to follow that set in the idyll of Theocritus which the Roman was himself imitating. ${ }^{8}$ For instance, the Greek shepherd is induced to sing by the offer of a carved ivy bowl, and of the privilege of milking a goat, things which he claims with childish eagerness the moment his song is finished. The fisher, like his Theocritean prototype, offers his comrade gifts, as an inducement to sing :

"Moss of the dark blue sea, purple-fish sought through the deep, with coral torn from the very lowest rocks."

One Greek swain and one fisherman render their respective laments entire, while in Virgil both characters render different parts of the complaint, after which they perfunctorily exchange a pipe

'Id. I. 
for a sheep-hook. The Greek goatherd's enthusiastic wish :

"Filled may thy fair mouth be with honey, Thyrsis, and filled with the honey-comb; and the sweet dried fig mayst thou eat of Aegilus"-

is adapted to piscatory conventions in Sannazaro's :

"Mayst thou ever have from the Megarian reefs nearby, an abundant supply of shellfish, and may Mergellina bear thee oysters, and the rocky cliffs, sea-urchins."

Other touches, such as fishing in a skiff by night, "watching for the tunny shoals," and mention of a smoky cabin, weels, nets, bait, hooks and fishing baskets plaited of withes, are probably borrowed from the Greek poet.

All the other fisher idylls of Sannazaro furnish similar examples of imitation. Virgil's shepherd boasts to Alexis ${ }^{7}$ of his thousand lambs, grazing on Sicilian pastures, which finds an echo in a fisherman's boast of a thousand oysters on the hanging cliffs of Misenum. ${ }^{8}$ The same rustic vaunts his oaten pipe given him by Damoetas, as to his successor in pastoral song, which the fisher matches with the boast of wool, dyed with the juice of the purple-fish, and softer than seafoam-_" this the shepherd Melisaeus himself once gave me, when by chance the old man from a rock heard me singing, and he said: Boy, this is the reward for your lay, since you are the very first to sing upon the seashore."

7 Ec. 2.

s P. Ec. 2. 
As Melisaeus is a poetical name for his master Pontano, Sannazaro here turns the Virgilian convention into a compliment to himself for the invention of fisher eclogues. Where almost every line in the piscatories is an imitation, it would be tedious to cite more parallels. Even the lists of trees and shrubs in Virgil become lists of fish in Sannazaro, and the pastoral refrain- "Begin with me, my pipe, the pastoral strain" finds an awkward equivalent in Sannazaro's " Thrust thy dark green face forth from the wave, O Triton."

Like most other Latin eclogues of the renaissance, these fisher pieces form an elaborate allegory, notable for obscure and puzzling allusions. Nevertheless it is not difficult to recognize some of the persons and events thus veiled from the casual reader. As has been stated, the first eclogue, a lament by the fisher Lycidas for the death of the fisher maiden Phyllis is the marine equivalent of Virgil's lament for the death of the mythical Daphnis. At the same time this fisher poem bears a strong resemblance to the last eclogue in the Arcadia, and the Phyllis of both poems is undoubtedly the fair Carmosina. This is asserted by a very early biographer, ${ }^{10}$ and accounts for the marked pathos characterizing the fisherman's song. Lycidas is Sannazaro, and Mycon, his sympathizing comrade, Basilius Zanchius. ${ }^{11}$ Cer-

Ec. 5.

${ }^{10}$ Vita by Vulpius, pp. 34, early eds.

${ }^{11}$ Cf. this epigram for Sannazaro's tomb by Zanchius: "These weels, these fishing lines, oh Syncerus, the fisher Mycon dedicated to thy tomb with his feeble art." A partial key to the eclogues is to be found in the epigrams and elegies by Sannazaro, and by others written about him. 
tain rivals of the poet's are alluded to in Mycon's speech of comfort:

"O Lycidas, Lycidas; dost thou not deem that happened more fortunately for her than if she had entered the smoky cave of Lycota, or had entered the hut of the hairy Amyntas? And now, were she alive, she would be seeking vile bait for her hook, or would be mending torn fishing weels with pliant withes."

Another very bitter passage tallies exactly with the facts known of this affair. The poet speaks, as in the Arcadia, of the very early age at which he fell in love, of his hope of marrying Carmosina and of spending all his days with her, and of his lasting sadness. Thus the poem combines imitation of the Virgilian bucolic with occasional borrowings from Theocritus, and the type of fisher eclogue thus contrived veils the story of the author's sorrows.

These three elements characterize all the other eclogues. The complaint of the fisher Lycon at the indifference of Galatea is a studied effort to render by marine analogy Virgil's shepherd's complaint at the cruelty of Alexis. Owing to the fact that this piece was considerably altered before publication, its meaning is somewhat obscure, ${ }^{12}$ but Lycon is certainly Sannazaro, and the nymph is probably Carmosina. "Beautiful Hyale," who "praises" the fisher's song- "Hyale who is descended from distinguished Spanish ancestors

${ }^{12}$ Julius Scaliger had an early copy in which were many things later changed by Sannazaro. These were strictures on Pope Clement for slowness in rewarding the poet. (Vulpius, Vita, pp. 45.) 
and whom so many lands and shores obey," is Joan of Aragon, wife to Ferdinand, King of Naples and son of Alfonsus. ${ }^{13}$ The passage recalls Sannazaro's place at the Neapolitan court, and "the haughty Amaryllis," the "dark Menalcas," and the nymphs who favored the poet"Praxinoe," the "daughter of Polybata," and the "wife of rich Amyntas" are to be considered appellations meant to disguise noble persons of his acquaintance. Melisaeus, as we have seen, is Pontano, who finds Sannazaro on the shore near the city singing the praises of Mergellina, and Lyda, who is "spiteful" because the garlands she sent Sannazaro had no effect on his heart, is a pretty girl to whom he paid poetical compliments. ${ }^{14}$

All the allusions to his life in these first eclogues indicate that they were composed before Sannazaro went into exile, but the remaining pieces were probably written at later periods. This is shown by various passages. The fisher Chromis, in the third pastoral, a song contest, speaks about the wanderings of Sannazaro's exiled prince with his followers, and Iolas relates the return of Lycabas (the poet) to the Lucrine Lake, with his account of the barbarous peoples in other lands. As the poem was among those brought back to Naples by Sannazaro in 1503 , the lines on his return are either an anticipation, or a later interpolation.

The singing match itself is modeled song for song on that in Virgil's seventh bucolic, but the

13 Ed. I 782 , pp. 20 I.

14 See bk. I., epigram 45. 
introduction and conclusion are notable for unusually direct borrowings from Theocritus. The first lines include an imitation of the Greek fisher idyll :

"Celadon. Tell me (for at Baulae, if Aegon reported the truth, storms, O Mopsus, held you during twelve days) what thou, what Chromis and what thy friend Iolas played in deserted caverns while the south wind swept the sea, and the waves moaned outside?

Mopsus. What could our Muses accomplish in such enforced idleness, O Celadon? Then we could not with impunity stalk shellfish on the ${ }^{15}$ rocks nor the light-footed paguri. The rocks now propped up our frail skiff on dry land, and wide-meshed seines hung on the long oars. Beside us were strewn the instruments of our craft, the light fishing creels, the rods of reed, the hooks, and lobsterpots woven of rushes."

Here we find almost word for word the list of implements given in the picture of the cabin of the Greek fisher Asphalion and his friend. One of the prizes, too, is taken from Theocritus:

"So far, O Celadon, under the resounding cliff I remember they contended in varied song, laughing at the rough murmurs of the windy deep. And then, too, they carried off praise with prizes worthy their singing, ones that Triton could not scorn. One of them gained a spiral shell that I, naked, captured under the swirling tide of Circejo, a shell stained with purple: the other received curving branches of knotty coral."

${ }^{15}$ The stalking of shellfish is taken from Th. id. 9. 
The setting of this pastoral is almost identical with that of the storm-bound fishers whom Alciphron pictures, but the influence of Theocritus is traceable in much of the imagery, the cave, rocks, "twigs and rushes best for plaiting weels," "light hooks," nets, etc. There can be no doubt that the realism and local color distinguishing this poem from the rest are due to a deliberate attempt to harmonize the realism of the Greek fisher idyll with the construction of the Virgilian song contest. It is a sort of kindly correction of Theocritus, showing how that kind of thing ought to have been done.

Many of the pictures of fisher life in these pieces may be traced to a source in Theocritus, but one of the pastorals, "Proteus," illustrates the fact that Sannazaro considered poetry dealing specifically with the gods of fishers as "piscatory," and that for such he found ample precedent in Virgil. The fourth georgic, for instance, includes a passage really equivalent to a marine eclogue, even beginning with description appropriate for the introduction to such an interlude:

"T'was noon; the sultry Dog-star from the sky Scorch'd Indian swains; the rivel'd grass was dry: The sun with flaming arrows pierced the flood, And, darting to the bottom, bak'd the mud, When weary Proteus, from the briny waves, Retir'd for shelter to his wonted caves. His finny flock about their shepherd play, And, rolling round him, spirt the bitter sea. Unwieldily they wallow first in ooze, Then in the shady covert seek repose. Himself, their herdsman, on the middle mount, 
Takes of his mustered flocks a just account.

So, seated on a rock, a shepherd's groom

Surveys his ev'ning flock returning home,

When lowing calves and bleating lambs from far

Provoke the prowling wolf to nightly war."

Aristaeus, who had caused the death of Euridice, binds Proteus in his sleep, in order to force him to unfold the future. The god changes himself into wild beasts, into fire and into water, but all is in vain, and at length he resumes his proper shape, and with green and flashing eyes demands the cause of this violence. A dialogue ensues, and Proteus declares that the fates will punish the youth for his wicked attack on Eurydice. He repeats the whole story of the affair, ending with the death of Orpheus, after which the poet remarks :

"This answer Proteus gave; nor-more he said,

But in the billows plung'd his hoary head;

And, where he leap'd, the waves in circles widely spread."

For such visualization of the powers of ocean and for emphasis on marine scenery Sannazaro had before him not only the example of Virgil and the Greeks, but also that of his master Pontano, whose works he edited with lavish praise. Pontano loved to picture Galatea, teazing shaggy Polyphemus from the waves, or green-haired gods with bands of nereids and tritons in full chorus, and his poetry teems with pictures of the same

${ }^{16}$ G. 4. Dryden, 615-630.

${ }^{17}$ 765-767. Cf. "Proteus was a herdsman and of seals though he was a god." Theocritus, 27. 
sea and the same coasts that Sannazaro made the themes of his song. His influence on the piscatory eclogues has been phrased in general terms, but the intimate connection between one of his poems and Sannazaro's "Proteus" has not been noticed. Pontano's eclogue "Lepidina cuius Pompae Septem," the first combination of pastoral with the epithalamium, presents the shepherd Macron, who sits with his bride Lepidina, and chats about their recent courtship in that very spot near the shore. ${ }^{18}$ Before them pass seven bands, or "Pompae," with song and dance. First trip shepherds and shepherdesses, chanting alternately, and behind them nereids and throngs of tritons. Then Triton rises from the billows and sings elaborate praises of the bride, and of the coasts near Naples, while sirens with a hundred nymphs bear golden gifts, and three hundred other sea-gods bring more. On these processions the couple (Pontano and his bride) make enthusiastic comment, and the whole poem thus has many of the characteristics of the later masques of sea-gods, since the dancers and singers are merely noble guests at Pontano's villa by the sea.

Sannazaro declared this piece "equal to Virgil," and he probably took from it the idea of making Proteus predict the mystery of the Incarnation in his epic, "De Partu Virginis," in which, too, nereids and other ocean divinities figure with singular prominence. A more obvious relationship, however, connects Pontano's idyll with his dis-

${ }^{18}$ Ecloga $\backsim$ "Lepidinus Cuius Pompae Septem." 
ciple's " Proteus," a pastoral dedicated to Ferdinand of Aragon, Duke of Calabria and son of Frederick, King of Naples, with whom the poet was an exile. One purpose of both eclogues is to eulogize Italy, the Bay of Naples and the coast, in both the deities and general marine convention are the same, and in both the panegyric is sung by a sea-god. As usual, nevertheless, Sannazaro is following a more definite model in Virgil, here the fourth pastoral, the famous "Pollio," once regarded as a messianic prophecy. Virgil's prediction of a return of the Golden Age with peace and happiness for Italy, after the birth of a wonderful boy, with its mood of patriotism, is closely paralleled by the humanist, who extols the youthful prince, and prohesies his safe return, with power over all the land, in an era of peace and glory for Italy. Incidentally he repeats his claim to the invention of fisher poetry, in these lines addressed to his lord:

"Now do not despise the Muse of the Seashore; whom for thee, after her sojourn in forests or in bristling groves of Bacchus, I was the first to lead down to the salt sea waves, if that is anything to boast, daring in my untried fishing skiff to attempt perils yet untried."

The second part of the eclogue is a variant on the song of Silenus in Virgil's sixth pastoral, which relates how two youths seized the god and forced him to sing them a mythological account of the universe, with special emphasis on Italian legends. Sannazaro's Proteus, amid a crowd of tritons, chants by night a more elaborate song, 
mentioning many events or places made famous by the Aeneid-Italian and Sicilian shores, the Cumaean sibyll, the caverns through which Aeneas passed to the under-world, with an enumeration of the Roman kings and wars. Finally, he eulogizes Virgil and Pontano, and pities the sad fate of Sannazaro himself, still in exile with his prince. Thus the sea-god's song combines the themes of two of Virgil's eclogues, and Virgil's chief contribution to the pastoral, the panegyric, finds a marine equivalent in the work of his humanist disciple.

The last fisher pastoral, "Herpylis Pharmaceutria," was dedicated to Cassandra Marchesia, Sannazaro's platonic love, and begins with her praises and with the statement that the piece was undertaken at her command. ${ }^{19}$ This passage is an imitation of the introductory eulogy of Pollio in Virgil's "Pharmaceutria," and in construction the humanist follows Virgil in a general way throughout. Yet though modeled in form and externals on the Latin bucolic, Sannazaro's poem, unlike all his others, is clearly the piscatory adaptation of an idyll of Theocritus-forsaken Simaetha's wild incantations performed to win back her lover, ${ }^{20}$ itself the inspiration of Virgil's lovecharm. Apparently in this single case Sannazaro appreciated the superior fire and passion in the Greek, and realized that the Latin imitation was undertaken simply as a poetical exercise.

Unlike Virgil, Sannazaro follows the example ${ }^{10}$ If the statement is true the piece may have been done after 1503 .

${ }^{20}$ Idyll 2. 
of Theocritus in picturing the condition of the afflicted girl as she comes down to the sea by night. A few passages will show the general nature of the imitations. The Greek damsel exclaims :

"I against Delphis am burning this laurel; and even as it crackles loudly when it has caught the flame, and suddenly is burned up, and we see not even the dust thereof, lo, even thus may the flesh of Delphis waste in the burning!"

The fisher girl shouts :

"Pluck white worm-wood from the field hardby. By these magic rites shall I strive to burn his very flesh-who has left me wretched, and destroyed my peace of mind .... this dry seaweed first, scourings of the swelling ocean, is strewn and is suddenly burned up: lo, even thus, Maeon, mayst thou be consumed even to the marrow."

The Greek-" Scatter the grain, and cry the while, 'Tis the bones of Delphis I am scattering," has its marine equivalent in the Latin:

"Thrice, Clearista, thrice burn together sea-moss with this crab without a pincer, and cry the while'Tis the entrails of Maeon I am burning."

Sannazaro does not mention the burying of the lover's raiment, as does Virgil, but instead attempts a fisher adaptation of Theocritus' use of the magic wheel to make the guilty man "turn and turn" about Simaetha's door. The fisher sorceress calls on the "fierce trigon" fish to sting Maeon to the heart, and bids another sea creature 
which can stop sailing ships, to cramp his cruel limbs. Again, the Greek maiden's "Lo, I will crush an eft, and a venomous draught tomorrow I will bring thee!" becomes in Sannazaro's pastoral, "Crush together the liver and spume of a black torpedoe-fish, and this venomous draught tomorrow I will send him. May he drink it, and may his pallid limbs grow numb!"

The meaning of the piece is a little obscure, but the fisher seems to be Sannazaro. He tells how he and "Galatea" once sat below a cliff looking out over the Bay of Naples, and of how he afterwards left Italy because she did not love him-“" I myself on account of thee forsook my comrades and my fishing skiff. . . ." These lines and others descriptive of his later exile in France have some of the pathos of the earlier elegy, but the conceits in the poem are very extravagant. Speaking of a poplar tree near which he first saw Galatea he declares:

"I embrace this again and again, and imprint my. kisses on the bark. Often I search for thy very foot-prints-and if I find any, I adorn them with flowers."

Besides this he boasts that he would not hesitate to swim a race against tunnies or dolphins, "with Galatea as judge." Thus a fantastic love complaint ends an eclogue which had begun with imitation of the incantations described by Theocritus.

It is known that Sannazaro completed ten fisher idylls, presumably imitating all of Virgil's, but that after his return from France only the five already mentioned, with part of a sixth, re- 
mained in his writing-case, the rest having been lost or stolen through the carelessness of his friends. ${ }^{21}$ The fragment pictures two rival bands of fishers meeting at the temple of Venus on the Lucrine Lake, where their champions, "both skillful sailors in the narrow seas, and both cunning fishermen, one in casting hooks, but the other in spreading nets in the ocean, ${ }^{22}$ are to hold a trial of skill in song. Of the actual match only a part remains, in which Zephyraeus calls on the muses of fishers, complains of the cruelty of Phoebe and Chloris, and then turns to magic charms for relief:

"Go, Goddesses of the sea, summon now for my madness other juices, other herbs of Melampos ... I have not shunned magic verses, the names of things unknown, and the unlike gods, Erebus and Chaos. Nay more, I have learned to whirl the mystic wheel with thread, by which I have drawn my share of sea-urchins from the shore, moss from the reefs, water from the waves."

At this point the eclogue stops, but even the remnant has interest as part of an incantation performed by a man who has been snubbed by two girls, the refrain in the poem:

"Give forth with me, at length thy song, my hollow shell," is the logical piscatory adaptation of the analogous refrain addressed to the reed pipe in earlier pastoral.

Sufficient has been said about these fisher poems to show that they may justly be character-

${ }^{21}$ Acc. Paulus Manutius in Vulpius, Vita, pp. 28.

${ }^{22}$ Cf. Virgil, 7, herdsman and shepherd. 
ized as Virgilian pastorals ${ }^{23}$ in form, but pastorals given a marine coloring. This becomes obvious the moment one places a few lines of Sannazaro's hexameter beside the corresponding lines in his model. In this book there is space only to mention the more striking resemblances, but a conparison of the original texts reveals metrical and verbal imitations which show that the humanist was very successful in catching the manner of his model.

Nevertheless some differences are marked. With all his skill as a Latinist, Sannazaro could not avoid a more ornate, elaborate style of composition than that which Virgil perfected. Occasional extravagant conceits, and the undertone of disappointed love suggest the legacy of Petrarch, while bitter reflections on exile, with eulogy of the shores near the poet's home, recall a trait of Dante's.

The chief defect that has been pointed out in these pastorals lies in the characterization of the fishermen, who have been termed merely shepherds in disguise. That there should be some ground for such a criticism is the inevitable result of Sannazaro's method. He chose to make his characters sing just the types of song which he found in Virgil, and to borrow many touches descriptive of the activities of fishermen from Theocritus. This was only natural in so enthusiastic a humanist, but though he culled from the classics the specific terms in which to frame his marine sketches, it is evident that he selected what fitted

${ }^{23}$ Aside from the imitation of $\mathrm{Th}$. 
with a reasonable degree of accuracy the things he could see from his Villa Mergellina at any time. Fishers hauling seines by torch-light, trapped on a barren coast by tempests, or gathering moss, oysters and sea-urchins must have been commonplace sights to the Neapolitan poet. Even in the matter of making his men sing he had precedent near at hand in the native madrigals of the coast. Moreover, his characters keep up a show of fishing at least as convincing as that which contemporary shepherds do of tending sheep, so that to criticize their artificiality is to ignore the spirit of renaissance pastoral, in which this quality is almost universal.

'Although Sannazaro's claim that he was the first to write fisher poems can not have been ingenuous, it was echoed by the most learned scholars of the day, and it would require many pages to print the eulogies in prose or verse which greeted the "new style." If the humanists realized the poet's indebtedness to Theocritus they did not mention it, and even such men as Erasmus, who regretted the liberties which Sannazaro had taken with the pastoral, admired the classic correctness of his Latin. Ariosto ${ }^{24}$ declared the eclogues a new literary species, and it is noteworthy that a considerable number of panegyrics took the form of fisher epigrams. All this admiration is easy to understand, because it was mainly due to the fact that Sannazaro had succeeded in composing very close imitations of Virgil, the idol of humanism. At the same time he was

${ }^{24}$ Orland. Fur. Cant., 46, st. 17. 
given credit for originality in making fishers his characters, and the beautiful coast of Italy the scene for their activities.

With the publication at Naples of these eclogues in 1526 the "new style" became a recognized literary type. By the close of the century ten editions of Sannazaro's pieces had been issued and numerous imitations had appeared, at first in Latin, then in the vernacular, then in special dialects. The convention spread also to other forms of literature, such as the romance, the drama, and the sonnet, and to other European countries, notably Spain, France, and England. The English branch grew from direct imitation of Sannazaro, and not from the Italian poems, so that only a brief account of the continental pastoral need be given here.

Turning first to imitations in the learned tongue, we find that these began with an allegorical ec$\operatorname{logue}^{25}$ by Sannazaro's friend Johannes (Giovanni) Cotta of Verona, in which a victory over the French in 1503 was celebrated. The patriotic and eulogistic cast of this poem mark it as akin to Sannazaro's panegyric, ${ }^{26}$ but the fact that the author introduces two shepherds conversing with a single fisher suggests that Cotta aimed to combine the bucolic motive with the piscatory. This tendency to effect a combination of the old style with the new appears also here and there among Latin poems that were written after the publication of Sannazaro's eclogues gave fisher pastoral ${ }^{25}$ Cotta died 16 ro, so the eclogue was composed before that date.

${ }^{2 \theta}$ Ec. 4 . 
a definite standing. A piece by M. Hieronymus Vida, for example, pictures a shepherd near the sea singing a song about Arion's dolphin ride, Proteus pasturing his seals, Glaucus, Amphitrite, Galatea and other sea divinities. This sort of compromise was aimed, ${ }^{27}$ apparently, to show that Sannazaro's marine imagery was not inconsistent with the older form of pastoral verse. These rustics were evidently those:

“... whose precious charge

Nibbled their fill at ocean's very marge,

Whose mellow reeds are touched with sounds forlorn By the dim echoes of old Triton's horn."

Such pieces embodied a mild correction of Sannazaro, reminding one of the traditional mixture of characters in classic pastoral, rather than being unconditional endorsement of the " new style."

Fisher eclogues, however, became more and more common, and after a time Casal Monferrato established an "Academy of Argonauts," in emulation of the "pastoral academy," and the members wrote of the sea, just as their rivals did of the fields. In addition to fisher eclogues, which by the middle of the century had attained a marked vogue, these poets tried variants, among them " nautical eclogues," in which the activities traditional for the pastoral were transferred ta the decks of ships, where sailors wailed love complaints, held song contests, or performed incantations by the light of the moon. ${ }^{28}$ Other poets of

${ }^{27}$ Another piece of the sort is by Johannes Baptista Amaltheus.

${ }^{28}$ Ferrante Bagno, ec. 2. 
the Academy devoted themselves to "dialogues on nautical art," ${ }^{29}$ and to longer didactic pieces about navigation termed "nautica." In most of these eclogues the conventions are very much the same as in Sannazaro's pastorals, and the distinction between strictly " nautical" and "piscatory" idylls is rendered a little hazy by the fact that even on vessels fishers are sometimes the singers.

Of the more direct imitations of Sannazaro practically all are allegories, and a large number consist of panegyrics and elegies. Some eulogize famous men, ${ }^{30}$ or Venice and the adjacent coasts, ${ }^{31}$ and it is probable that the church regarded the new pastorals with favor, partly because Sannazaro and his followers carefully avoided strictures on religious abuses of the sort emphasized by Mantuan, and partly because fishing had always been held a particularly honorable craft because of those whom Christ once made "fishers of men." At any rate, a great many ${ }^{32}$ fisher eclogues were written by churchmen, dedicated to the Pope, or devoted to lavish praise of the church, the Pope and the prelacy in general. These pieces bear a dreary family resemblance, and when the vernacular poems grew popular they gradually became less common. The most successful of all these Latin works, thirteen fisher eclogues by the Jesuit Nicolaus Giannetasius (Parthenius) were published at Venice in

${ }^{28}$ G. I. Bottazo, 1547, and G. Antonio Taigeto.

${ }^{30}$ E. Carrara, Poesia Pastorale, fasc. 40.

${ }^{31}$ G. M. Verdizotti, Rome, 1566. Lorenzo Gambara, Rome c. 156r. Goina, c. 1550 .

${ }^{32}$ Thus, like the contemporaneous bucolic, the piscatory exemplifies the combination of the classic forms with allegory concerned with Christianity. 
I685, one hundred years after the humanistic variety had ceased to be of common production. ${ }^{33}$ They are the closest of all imitations of Sannazaro, Virgil, and Theocritus, in some places being mere centos of translated passages. He describes an ivy bowl, for instance, on which is carved an ancient fisherman with a net, and the lines giving the picture are taken almost word for word from Theocritus. $^{34}$ Again, his lament of Mopsus for the death of Thyrsis is copied deliberately from Sannazaro's "Phyllis," even to the deification of the departed. The persistence of the recognized characteristics of the Sannazarian form is well illustrated by these poems, and the fact that such work was still enjoyed by learned readers is indicated by the numerous editions through which Parthenius' pastorals passed. Evidently, too, they led to a revival of interest in Sannazaro, whose idylls were republished in $1689,{ }^{35}$ and thereafter at frequent intervals until $\mathrm{I} 823$, when they were translated into Italian by Biondi.

\section{Italian Eclogues}

The introdyction of fisher eclogues in the vernacular, like the other steps in the development of the species, followed after an interval the composition of Italian bucolics. The Marchioness of Pescara suggested ${ }^{36}$ to Bernardo Tasso the idea of "doing in the vulgar tongue what old

${ }^{23}$ The eclogues of Parthenius were pub. in 1685,1686 , I689, I692, I 696, I 710-I 4, I 722.

as Idyll $\mathrm{I}$.

${ }^{35}$ After a lapse of 89 years.

${ }^{2} \mathrm{E}$. Carrara, pp. 393-4. 
Sannazar had done in Latin," and he accordingly inserted in book two of his "Amori," 37 the first Italian imitation of Sannazaro published. In this piece Crocale, a nymph of royal blood, born near the sea, bewails the death of her fisher husband, Davalo. Her lament on the rocky coast and many of the details, such as invocation of the nereids with touches of marine description, recall Sannazaro's "Phyllis," but the second part of the poem is in a class by itself. "Beautiful Galatea " rises from the waves, embraces Crocale and begs her to lay aside her grief and marry Nereus, who wishes to make her queen of the ocean fields, of the green-haired gods and the scaly herds. As Crocale, Davalo and Galatea are poetical names for real persons, the idyll is as much a cryptogram as its Sannazarian model. This allusive element is less noticeable in most vernacular pastorals, but the elaboration initiated by Tasso's experiment, which is much longer than any of the Latin eclogues, continues to characterize the Italian fisher poems.

The latter, as a rule, follow more closely than Tasso the form of Sannazaro's pieces, and like them avoid the themes of religious controversy or political satire. Those few not based on a definite model by Sannazaro render in marine imagery pastorals of Virgil of which no Sannazarian imitation is extant, or else attempt a realistic treatment suggestive of Theocritus. The typical meter for Italian fisher idylls, as for contemporary bucolics, is terza rima.

:2 Venice, 1534. 
The eclogues by the Neapolitan Bernardino Rota, probably composed a year before the publication of Tasso's marine, though not printed till much later, ${ }^{38}$ are said to be the first piscatories in the Etruscan dialect, and are declared by Tiraboschi ${ }^{39}$ to be the best of their kind. Like Crocale's complaint they are imitations of Sannazaro, and it has been suggested ${ }^{40}$ that Rota, like Tasso, undertook their composition at the suggestion of the Marchioness of Pescara. They exemplify better than Tasso's poem the characteristics of the Italian fisher eclogue, and differ little in essentials from imitations made two centuries later.

In renaissance pastoral fishermen are an amorous lot, and Rota's are no exception to the rule, for twelve of his fourteen marines deal with love motives. His love-sick fishers wail complaints along barren beaches, or hold song contests before judges, or prepare incantations to win back their fickle nymphs-all much as in Sannazaro. What distinguishes these and most other Italian pieces of the sort from the Latin is not the subject matter or the form, but rather the method of presentation, which is much freer and more fanciful than in the humanistic works. When fishermen sing the charms of their sweethearts nereids chant like enthusiastic praises from the sea; Proteus appears driving his herds, while Tethys and Amphitrite scatter pearls and corals on the waters. In the love complaints we find one

${ }^{39}$ Naples, I 560 and 1572.

${ }^{39}$ Storia Della Litterat. Ital. I, ch. 30.

${ }^{40}$ E. Carrara, pp. 393-394. 
neglected fisher exulting because the gods have punished his nymph by turning her into a white stone; another finds himself mocked by an echo lurking among the rocks along shore; another serenades a sleeping girl, and still another is loud in his abuse of his would-be mother-in-law. Everywhere we find a singular mixture of modern life with ancient fable. Rota gives, for instance, a realistic description of two weary fishermen, but before he has done with them they find stretched in the seaweed at high water mark, a scaly triton, fast asleep, with his spiral shell lying at his side. One awkwardly attempts to sound the horn, whereupon the owner starts up, takes the shell and plays sweetly for them. Such themes contrast sharply with that of a single idyll in which two rude fellows chaff each other in vigorous fashion until interrupted by a comrade. This is imitated from the rough banter between Menalcas and Damoetas in Virgil, ${ }^{41}$ and is a fairly successful attempt to employ a traditional device to paint a coarse picture of modern fishermen.

Most of these poems are only variants on Sannazarian models, but they possess a freshness and charm superior to those in the Latin. This is due in part to Rota's exuberant fancy, but more to the fact that his descriptions of persons and scenery are comparatively original, while Sannazaro's are in most cases carefully studied marine equivalents for corresponding passages in Virgil. This comparative freedom of presentation be-

${ }^{41}$ Ec. 3. 
comes a permanent feature in the Italian piscatories, which oddly enough, with whimsical changeability, continue to place in juxtaposition, vivid if conventional imagery, with a use of pathetic fallacy far more extravagant than anything in Sannazaro. Thus the shores and seas are real enough, yet when lovers sing, fishes frequently pop their heads from the waves, listening in ecstacy to the pleasing sounds, or lose their heads and swim eagerly ashore. Rota composed piscatory poems and bucolics side by side, and as the new style spread, most sets of eclogues, whether in Latin or Italian, included a few written in the new manner.

In contemporary pastorals of shepherds, as a rule, pathetic fallacies are as noticeable as in those about fishers, and the oddities of the new species develop in emulation of and parallel to those familiar in the old. Lists of flowers are matched by lists of fish, the power of love evidenced by examples drawn from the ways of birds and animals in Tasso's Amyntas is shown with what may be termed marine flourishes by illustrations drawn from the lives of fishes or of seals in Ongaro's Alceo. This is the Sannazarian method. His Arcadia gave tremendous impetus to the popularity of the regular pastoral and his piscatories in like manner led the way to the "new" idea in pastorialism.

Not long after Rota composed his eclogues the fisher motive invaded another field of the pastoral. Sannazaro was responsible for the introduction of the piscatory convention, and as his 
Arcadia won great popularity, it was inevitable that some zealous imitator should write a romance of the seashore where fishermen should be the characters. This is exactly what happened, and in the work of Matteo Sammartino we find rather an ingenious combination of the new manner with the old, the prose and interspersed eclogues dealing wholly with fishers and an idealized fisher life. ${ }^{42}$ In similar vein Giulio Cesare Capaccio wrote a romance of which the prose celebrates Sannazaro's Villa Mergellina with the nearby coasts, while the eclogues are vernacular imitations of Sannazaro's Latin pastorals. Other marine Arcadias followed, and the species lingered on as late as the middle of the eighteenth century. ${ }^{43}$

With the exception of romances most of the fisher pastorals thus far mentioned were published at Naples. From that city the idea spread to Venice, where was published about $155^{\circ}$ an anonymous poem, "Pescatoria Amorosa," a serenade sung by fishermen, and notable for a certain lyric grace, ${ }^{44}$ though soiled by a vicious double meaning. The same year the Venetian Andrea Calmo published his "Rime Pescatorie," 45 in which the classic types of song are preserved but an effort is made to gain realism of presentation by reproducing the rude diction of actual Venetian fishermen, an attempt almost analogous to

42 Venice, 1540 and 1566.

4 Parini composed one some time before 1759. It has been lost.

"See W. W. Gregg, pp. 3*4.

43 "Le Bizarre, Faconde et Ingeniose Rime Pescatorie" repub. 1557, I 576 , I 582 . 
that made by Spenser in some parts of the Shepherds Calendar. ${ }^{46}$ Of all the piscatories printed at Venice, however, the four among the "Egloghe Miste" (I590) by Bernardino Baldi, Bishop of Guastalla, are the most interesting, on account of the sly humor with which the poet evidently regarded the occasional extravagance of the convention.

This mood is perhaps most pronounced in a complaint by a wretched fisher, who sits shivering in the boughs of a tree before the cabin where cruel Tibrina lies sleeping on a winter's night. The song is extremely elaborate, but follows the form of Sannazaro's Galatea, in invocation, attempts to excite jealousy, offer of piscatory gifts and the usual threat of suicide. The classic touches in this serenade border on the burlesque, the lover declaring with poor old Polyphemus:

"I am not deformed nor ugly if the tranquil sea where I go fishing tells the truth. If my chin is bearded and my eyebrows are shaggy - these things ornament men."

Another typical illustration of Baldi's manner is the fisher's sobbing reference to his tender recollections of how Tibrina looked in swaddling clothes. Equally absurd are the remarks about the power of love among the fish incidental to a confidential chat between two fishermen, and the detailed advice with which one fellow shows the other that he must use the craft of the angler to catch the heart of his indifferent mistress.

One of these eclogues, "Alceo," was very

${ }^{48}$ Analogous also to a movement in contemporary bucolics. 
likely composed for dramatic rendering. ${ }^{47} \mathrm{~A}$ young fisher, Cebisto, finds old Alceo vainly striving to row ashore against wind and waves. He yells to the oarsman to cast a line ashore, but it is some time before the deaf old fellow understands, and is hauled to safety. It is pouring rain and the two carry Alceo's basket of fish to the shelter of a cave. There Alceo asks whose name he sees carved on the rocks, whereupon Cebisto says that Tratilo has cut the name of his love on a thousand rocks - but there is a different name on every one. While they talk an eel slips from the basket and for some time they struggle to recapture it, which one of them succeeds in doing by holding dry leaves in his palms. After this episode Cebisto coaxes Alceo to tell what he knows about fish, and the garrulous old man, easily flattered, repeats a string of stories concerning marvelous sea-creatures. $\mathrm{He}$ goes on and on, encouraged by his auditor's admiring comment, but at length says he could keep it up a whole month, but must go to the city to change his fish for gold. The form of this piece, with the dramatic episodes, apt contrast of character, exclusively conversational rendering, and unusual length, indicates that it may be an "ecloghe rappresentativa," perhaps intended to satirize in dramatic presentation some of the favorite bits of fish lore found in Italian eclogues. ${ }^{48}$

${ }^{47}$ The other piece is a conventional allegorical eulogy for Ferrante, lately dead. It is imitated from Sannazaro's Phyllis. A touch from Theocritus is "Poverty which never sleeps and never concedes a full rest."

${ }^{48}$ The old man insists on the truth of all his statements, and the youth declares that he believes them all. 


\section{Tile Fisher Drama}

Meanwhile the fisher conventions made their way into the drama in exactly the same manner as earlier into romance. Tasso's pastoral play "Amyntas" met with extraordinary success and among numerous imitations adaptations to the "new style" soon found a place. It is interesting to note that Tasso himself thought favorably of the piscatory idea, and at one time intended to compose a drama of fishers as a companion piece with his Amyntas, a scheme suggested by Signor Alessandro d'Este, who between 1580 and I 582 wrote, reminding him of the triumph of his pastoral, and urging that he should try his hand at a maritime or fisher play. The poet replied in this sonnet:

"O child of high talent, in the midst of the waves was born the goddess who is honored by Paphos and Cnidos, as is known to fame, by old report, and she still loves the sea and its shores. Not only among rough trunks and green leaves does she make a sweet nest, but in the cavernous reef and on salty bank, with her little boy, sometimes she hides herself. Then the fugitive Cyclops Galatea calls forth from a high rock in the waters. The seals and the whales are consumed with love, and if when I celebrated with bold song the shady woods, and the song was liked let it be liked if I shall exalt the sunny sands."

A little later Tasso wrote a second sonnet, in which he relinquished the idea:

"O holy son, born of great leaders, little boy Alessandro, in vain dost thou desire me to sing of 
rough man who raves and loves, and dost wish that my song may accompany thy sports, either along a pretty river, or yet beside the lively founts and under the green branches, or yet among reefs and waves and nets and hooks, grieving for love, sighing and weeping. It seems that I (who many years ago wrote plays), can not now write so far from the woods and the shores. Place me (it is time) where the green top of the thick wood is moved murmuring, and the placid sea stirs beneath the summer breeze."

But though Tasso gave up the idea it occurred to the young Antonio Ongaro at just that time, for in the summer of $158 \mathrm{I}$, at Rome, was played his "Alceo," of which the plot is taken directly from the Amyntas, but in which the scene is changed to the seashore. The imitation is so obvious that the piece has been aptly termed "Amyntas soaked." Almost every passage in Tasso's drama is paralleled by its marine equivalent-Venus dons the dress of a fisher maiden and determines to humble the cold Eurilla, who scorns the fisher Alceo. The latter is aided and comforted by the fisher Timeta, while Alcippe strives in vain to soften the heart of Eurilla. Tasso's lustful satyr, lurking near the pool to seize the shepherdess, becomes in Ongaro's play an equally lustful triton, hiding in a harbor to catch the fisher girl with her nets. ${ }^{49}$ Of course his wicked attempt is frustrated by the valor of Alceo. Even the Golden Age chorus in Amyntas

${ }^{20}$ He utters a complaint like that in Sannazaro's Galatea, and says, like Polyphemus "When I look into the quiet sea, I do not think I am a monster." 
finds an echo in a chorus of fisher folk, praising life by the sea. Of course at the end Alceo takes the same leap as does the hero of the pastoral drama, only the fisher leaps to the sea, and jumps twice before the heart of his mistress is softened by his devotion. ${ }^{50}$

Another evidence of the vogue of the fisher convention $^{51}$ is found in the sonnet. Those by Tasso already cited may have suggested the idea of composing piscatory sonnets to others, for in the next century occasional pieces of the sort made their appearance. Of these the following, by $\mathrm{A}$. Marchetti, is a typical example:

"Nice, now that the star of love is rising from the orient, and with disheveled hair shines with pure and divine beauty, the messenger of a new, clear dawn-take the nets, and in this little boat, come and fish for ragui and soles and ombrine. Of them in the quiet neighboring waters we will make an abundant and beautiful catch. Come, do not fear that suddenly the calm of the sea be disturbed, as often is wont to happen, by the tempest or wind; because thy sweet looks, thy words will make the sky smile and every element, and clearer than ever will the sun be born."

Thus fisher pastorals of many kinds became common in Italy after the publication of Sannazaro's poems. During the next century they were not so frequently composed, but the genre lin.

${ }^{50}$ Acc. Angelo Solerti similar imitations of Amyntas were common for more than a century. One is a "Favola Pescatoria," Venice, 1612. Battista (Giovanni) Ruffino.

${ }^{51}$ Another set of Italian piscatory eclogues imitated from Sannazaro by S. Berardino were published at Naples in 1560 , "L'egloghe Pescatorie." 
gered on, and so late as the middle of the eighteenth century we find in the works of Parinis2 evidence of the persistence of the seaside pastoral. He wrote a fisher romance, in imitation of the Arcadia, bucolic eclogues, piscatory eclogues, and the following sonnet:

"I am dying at last, $O$ cruel Eumolpi, on these wet nets in the boat where thou seest me lying; but I will not accuse thee of still grudging me a cold sigh. O scaly herds, no longer fear the blows of my trident; at last is departing for other shores he who with every net was wont to draw from the waves a full load of tenie and polypi. Take, o my companions, my rods (Ah a thousand times be it given to you to see their tops bent!) or my nets. Only this little boat shall come with me, to cross, black Styx, thy whirl-pools, when Charon will deny a passage to so unhappy a wretch."

This piece differs in no essentials from those composed a hundred years earlier, and the same thing is presumably true of his romance, ${ }^{53}$ and certainly true of the three fisher eclogues among his pastorals. Two of the latter are love complaints bearing exactly the same relationship to Sannazaro's work ${ }^{54}$ as do the eclogues of Rota, written nearly two centuries earlier, except that like the pieces produced in the late sixteenth century they display a humor that marks a reaction against pastoral affectations. This tendency is most pronounced in the last idyll, one of rude

${ }^{52}$ Poesie, Firenze, 1889.

${ }^{53}$ Composed before 1759-now lost.

st "Galatea." 
banter imitated ${ }^{55}$ from Virgil. One fisher is accused of singing as sweetly as a scratching file, so that a band of frogs fled in dismay. He replies that the sea-goddesses burst with laughter when his rival sang. In the contest that follows these insults Nilalga declares that his fisher girl has golden hair-the gold with which the salpi sparkles, and the shining eye of the gold-fish. One day she kissed him, whereupon the fishes along the shores "swam to and fro full of envy." A good example of Parini's manner is furnished by the designs which he describes on a bowl, ${ }^{56}$ in which

"is cut a fisherman, who standing on a high reef is preying on the frisking schools with rod and hook. Near him are three laughing children, who gather the prey on the beach, and then play among themselves. And here is one who, intrepid and daring, a companion clutches by the hair because he has stolen a fish. Here four young girls are washing their pretty, white feet in the shade of a clump of bushes. They are sitting on the soft, green grass, and with their skirts lifted higher than their knees, show their pure and alabaster legs. Then a troop of tritons is laughing at the unwary and inexpert four from behind a rock."

So much for late survivals of the orthodox piscatory conventions. Examples of Italian fisher poetry of later periods, such for instance, as $\mathrm{Li}$ Piscaturi, ${ }^{57}$ by the Sicilian Giovanni Meli, are little influenced by the Sannazarian manner, and

${ }^{55}$ Ec. 3.

${ }^{6}$ From Theocritus, or from the imitation by Parthenius.

${ }^{57}$ See Opere di Giovanni Meli. Palermo, 1838. 
are rendered in various free and vigorous lyric forms.

The Spread of the Fisher Pastoral to Spain AND France

The well-known subjection of Spanish literature, particularly of the pastoral, to Italian models ${ }^{58}$ during the first part of the sixteenth century was probably due as much as anything to the similarity of the languages, which facilitated the transference of Italian verse forms into Spanish, and the introduction of such forms was the more natural in that the native pastoralism of popular tradition formed precedent for the poets. In Spain as in Italy, successful imitation of the classics by those who attempted the more strictly Virgilian form of pastoral, or renaissance variants of that form, preceded the composition of fisher eclogues. Thus, to be exact, we find that Spanish imitations of Sannazaro's Arcadia and of the poems in that romance led the way to imitation of Sannazaro's piscatory idylls.

Precedent for imitations of these pieces had existed from the very earliest times in the native fisher songs along the coasts of the Galaico-

${ }^{58}$ The earliest evidence is found in the eclogues by Garcilaso de la Vega, comp. 1526?-pub. 1543. These are based on eclogues in the Arcadia. Other imitations of Italian models are by Boscan, Mendoza, Cervantes, Lope de Vega, Pedro de Encinas and many more. The Arcadia was first imitated by the Portuguese Bernardim Ribeiro (1475-1524) in his "Menina e Moca." A Spanish translation' of the Arcadia appeared in 156r. Jorge de Montemôr's Diana (1561) is influenced by Sannazaro's romance also. 
Portuguese region, so that just as rural Galicia is thought to have left its stamp on the exotic bucolics, the lyrics of the shore may have affected the analogous renaissance piscatories. At any rate such lyrics are of common occurrence in collections of old songs, ${ }^{59}$ in "villanescas de mar," and in "vers de ledino." These constitute a species by themselves, perhaps akin in origin to other native lyrics of fisher folk among the romance peoples. They are usually songs with refrains, mere snatches of melody suited to the rough toils of fishermen, and giving the effect of having been composed to the swing of the oar. There is a sad note in most of these pieces, and in many cases the same suggestion of unrequited love, which forms the favorite theme of the fisher pastoral in Italy.

It is not surprising, then, that the first imitation of Sannazaro's Latin eclogues in Spain should be found in the work of a Portuguese, Louis de Camões, whose experiment in the genre, the "Song Contest," may have been composed as early as 1546 . In the introductory lines expressing a determination to repeat the contest that once arose between the singers of the pastures and of the seashore, the poet declares that he will sing in a way once followed on another shore by "a man beloved by the Muses-Sincerus the fisherman," but that he will "enter the domain of the new style true to Virgil, without deviation." Accordingly he tells how the shepherd

${ }^{60}$ Martin Codax, in particular, seems to have dedicated himself to this sort of poetry. Juan Zarro wrote pieces very like modern " barcarolas." See bib. "Pelayo." 
Agrario, in a sad reverie, left his flock and wandered to the coast, where in a cavern he heard the fisher boy Alicuto singing about Lemnoria. The charm of the fisher song filled the rustic with admiration, and a conversation ensued, ending with an agreement to hold a contest. This match took place before throngs of shepherds and fishers, ${ }^{80}$ and the alternate strains place side by side the new manner in pastoral with the old, all Alicuto's words being deliberate imitation of the songs in Sannazaro's contest between fishers, while Agrario's utterances are imitated from the corresponding trial of skill between swains in the Virgilian eclogue which Sannazaro rendered marine. ${ }^{61}$ Thus the piece is based both on Virgil and on Sannazaro. At the same time Camões' employment of pathetic fallacy shows that he was influenced by the fantastic conceits of Italian fisher pastoral, and so we find that when his Alicuto sings, fish pop their heads out of the water in ecstasy, while dolphins race madly along shore. In spite of its artificiality this poem has a color and freshness which show that even in adapting at once two rival forms, Camões was too much of a poet to produce a stilted rendering. He was equally successful in his complaint of the fisher Sereno to Galatea, "The Scorned Fisherman," a piece imitated from Sannazaro alone. ${ }^{62}$ The elaboration of both these fisher pastorals is greater than that in most contemporary Italian eclogues. Camões termed fisher pastoral "the new style,"

${ }^{60}$ Cf. Sann. fragmentum.

${ }^{61} \mathrm{P}$. ec. 3 .

2 Ec. 2, "Galatea," 
and his example may have suggested to Diogo Bernardes the idea of attempting further imitation. Two of his eclogues, "The Fisher's Wooing" and "The Fisher's Lament," published in $1596^{63}$ are so like poems by Camões that they are sometimes printed with his works, and at the same time they are modeled on the pastorals of Sannazaro. The first of these idylls is another imitation of the humanist's oft-imitated "Galatea," and the second is merely a variant on the same theme, though it attempts the realistic detail of Theocritus. Thus the fisher Meliso's plaint is wailed to the moon-lit sea, and near him lie his old fishing boat, with the sails, spars, seines and tackle under shelter on the beach. One touch suggests the myth of Arion. The singer tells how he once sat in his skiff moaning a complaint to his cruel. Lilia, when emotion overcame him, so that he fell senseless into the waves. Luckily a soft-hearted dolphin, moved by his sweet voice, bore him back to his boat in safety.

Of somewhat later composition than these pastorals is Calderon's "El Golfo de Las Sirenas," which he styles an "Ecloga Piscatoria." The passages on fisher life recall the conventions characterizing many idylls already considered, but the piece is rather a short play than an eclogue, and is an isolated example of the occurrence of the motive in early Spanish drama. A few words will suffice to give an idea of the plot. In the spring a gallant fisher, Silenus, a boorish fisher,

¿ One was printed in Bernardes' "Olyma" as "Galatea," ec. 2. The other was printed as "Lilia" ec. pisc. 13. (See Storck's Ger, tr., pp. 423 fol.) 
Alfaeus, and two village maidens, Astrea and Celpha, chance to meet. It is proposed that they ascend the mountains, with music-girls and village choruses, to celebrate the season with its deities, but Alfaeus reminds them that Scylla, rejected by Neptune for Amphitrite, has retreated to the hills, where she remains unrelentingly bitter against all seafolk, whether gods or men, and that to see her is fatal. Nearby amid the reefs lurks Charybdis, daughter of the sea god Aglaucus and of a siren. She hates sea-farers because Aglaucus spurns her mother, and her voice leads sailors to destruction. Fisher-folk have an understanding with these grim deities, and must not worship others lest vengeance come upon them. As they talk a wreck is sighted and the cries of Ulysses and his crew rend the air. Scylla and Charybdis call down destruction upon them, but nevertheless Ulysses with two servants is saved. Scylla now disputes with Charybdis as to which of the two is more baneful, Scylla who kills by the eye, or Charybdis who kills by the hearing. The debate is very subtle and clever, the poet here defining the esthetics of the eye and of the ear. To settle the difficulty they agree to try their power on Ulysses, who is to be the exclusive victim of the winner. In the contest now one, now the other, seems to be winning, and the Greek is filled with conflicting emotions, but he is rescued by his followers, who lead to him Celpha and Alfaeus, by whom he is warned of his danger just in time. He procures a skiff, in which he embarks with the fisher as an unwilling pilot. The enraged 
gods rouse earthquakes, while Sirens strive to attack Ulysses, but the wily prince escapes. The reefs Scylla and Charybdis are thrown up by the convulsion. Ulysses casts Alfaeus into the sea, where he is swallowed by a monstrous fish which later disgorges him on the shore. The fisherman now hears within a hollow mountain the voices of maidens, beseeching him to free them from the dungeon in which they are imprisoned by Scylla under the care of a savage. He refuses his aid, but the hideous guardian appears, and begins to prate "old wives" tales to him, and on his scorning these the savage conveniently dies. "He that listens not to a savage doth kill him." Among those thus rescued is Celpha, whose gratitude to the fisher makes them forget their former dislike for each other.

The play has little in common with Italian dramas like Ongaro's Alceo except fishermen as characters, and even they are not nearly so important as the powers symbolized, with the allegorical treatment of their employment against Ulysses. In spite of Calderon's calling the work a piscatory eclogue, then, it has little connection with the Sannazarian species so far as structure is concerned. The case is different with the Spanish eclogues by Camões and Bernardes. These resemble the Italian imitations of Sannazaro in their ornate and lengthy treatment, but differ from them in the retention of more numerous specific touches suggestive of their common models. Such poems seem to have been only of sporadic occurrence in Spain, and do not indicate 
that the foreign fisher idyll ever gained much of a foothold in the peninsula. They illustrate, however, the wide dissemination of the fisher pastoral that followed Sannazaro's work.

\section{The Piscatory in France}

The fisher eclogue made its way into French literature in the same manner as into Spanish, following imitation ${ }^{64}$ of other Italian pastoral forms after a short interval of time. At a time when the Pleiade group of poets in France was urging the exaltation of the vernacular through imitation of the classics, it was inevitable that Sannazaro's idylls should meet with approval, because of his remarkable success as a Latinist. The stamp of official approval, in fact, was emphatically given to his eclogues in the famous manifesto of the Pleiade, "La Défense et Illustration de la Langue Francaise." Du Bellay recommended the composition of pleasant rustic eclogues after the example of Theocritus or Virgil, and of marine eclogues after the example of Sannazaro.

The first to follow this dictum concerning marines was another distinguished member of the Pleiade group of poets, Remy Belleau, whose "Bergerie" owes much to Sannazaro's Arcadia.

${ }^{4}$ Thus Margaret of Navarre made a French translation of Sannazaro's “Salices," I 543: “L'Histoire des Satyres et Nymphes de Diane." In I544 Giovanni Martin translated the Arcadia. Du Bellay himself translated and imitated parts of the Arcadia. His "Jeux Rustiques" owes much to Arcadia, and to Sannazaro's P. Ecs. and to his Latin epigrams. 
This indebtedness is traceable in the general plan of the French work, made up as it is of prose passages and of eclogues, ${ }^{65}$ and in occasional specific imitations. ${ }^{\circ}$ The story of Sannazaro's first exile in France, of his return to Italy and of the death of Carmosina is veiled by the idealized pictures of shepherd life in the Arcadia. The "Bergerie," on the other hand, is rather an eulogy of sixteenth century France, and is aimed especially to describe the charm of country life during the various seasons.

In one part of the work, the "Seconde Journée," fisher eclogues figure as a literary "tour de force," intended to show how gracefully that sort of thing could be handled in French. Each poem is preceded by an appropriate prose introduction, the first of which represents a party strolling through a formal garden, where they heard the voice of a fisher on the banks of the river Marne. As they drew nearer they saw the singer, a handsome youth, fishing with hook and line. He had stationed himself below an overhanging rock on purpose to wail "complaints to the wind and waves," while his skiff with the tackle lay nearby on the sands. Belleau does not explain how a towering cliff and "rough billows" happened to be found at the foot of the trim garden. among the willows, but they were evidently needed as a background for what followed. The

${ }^{\text {es }}$ And other lyrics not modeled on formal eclogues, like the beautiful lyric "Avril."

"As in Belleau's "Winter," where borrowings from Arcadia prose 9 and prose 10 are found. Part one of "Bergerie" pub. 1565. Part two and the p. ecs, 1572. 
fisherman was in love, and as soon as he saw the newcomers "he began to sing aloud as if he had sworn to please us." His first words are an apostrophe to Poverty, probably borrowed from the induction to the Theocritean fisher idyll. After this he tells how love has come in the guise of a fisherman and "baited his hook with Catin's eyes" which the singer has swallowed and so been caught. His complaint to this damsel is merely a French rendering of the analogous one in Sannazaro, but curiously enough, he is stated to have sung it "till night," and yet the audience did not grow impatient. On the contrary Belleau says:

"I promise you this gentle fisher gave us so much pleasure, and recited his passionate eclogue with such good grace that he made us forget our talk ... he told us that he had once been on the sea and that an old Sicilian mariner had taught him the complaint, with an infinite number of others that we made him tell us."

One of these, "The Fisherman," dedicated to "Lord Antoine de Baif," is a French imitation of Sannazaro's song contest, ${ }^{67}$ composed with many realistic touches, ${ }^{68}$ such as a cavern for a background, skiffs, tackle left lying in confusion, and fishermen all along the beach drawing fish from their hooks. Having rendered this piece the youth handed to his listeners a paper on which were traced "Larmes Sur Le Trespas De Monseigneur René de Lorraine, Marquis d'Elbeuf."

Ec. 3.

${ }^{e s}$ As in Sann. and Theoc. 
This proves to be an elegiac eclogue in which three fishers lament the death of the marquis, and extol his virtues, and his victories in naval battles on many seas, all of it modeled on Sannazaro. ${ }^{60}$

The fisher is so obliging as to sing also lines on the "Tombeau de Madame Loyse de Rieux Marquise d'Elbeuf," a marine elegy in which the poet calls on the Nereids, who wept when Thetis mourned the death of Achilles, to weep for the French Marquise. In the course of the eulogy Belleau invokes Palemon, Glaucus, Panope and many other divinities of ocean. In another piece a shepherd who has lost his way by night peeps through the window of a cabin where he sees an old woman performing incantations and transfixing a waxen image, to win back "him who put her in such frenzy."

Lastly Belleau's fisherman proves that he is weather-wise by two songs, one on the celestial appearances of the sun, and the other on those of the moon, "astronomical eclogues," like some of the "idyllia" of Ausonius, only much shorter, and perhaps meant as French adaptations of a leading motive in Virgil's first Georgic. Thus the French poet makes a single fisherman render in French the themes of all Sannazaro's piscatories, singing a contest, a love complaint, an elegy, and a "pharmaceutria." The eclogues are graceful imitations, but rather more artificial than most earlier examples of the kind. The neat garden, the wall, and the willows along the stream are difficult to harmonize with the songs sung by

${ }^{60}$ Ec. I. 
the Sannazarian fisher. He poses with marked assurance, and his knowledge of astronomy, with the approving comment of the fashionable audience, listening with delight to all his songs, make a mixture that it is impossible to match elsewhere in the development of the new pastoral. It is only fair to this angler, however, to say that he is scarcely more courtly and polite than Belleau's shepherds. His artificiality is simply that of the pastoralism of France at this period, and whatever he does he hooks no dark fish to match the sooty fleeces worn by the mourning sheep in the eclogues of Marot.

One year after the publication of the "Bergerie" appeared what Estienne Jodelle called "Les Pescheries, Bergeries et Eglogues de Chasse de Claude Binet." 70 Of these the only fisher eclogue proves to be a short piece in the Sannazarian manner, giving the prayer of a fisher to Neptune, king of the sea. It is likely that Binet's experiment was suggested by Belleau's pastoral, but the only considerable work inspired by the "Bergerie" is "Les Pescheries," by Christophe de Gamon (1598). The eclogues and monologues of which this consists include many passages imitated from Theocritus, Sannazaro and Belleau, but the fisher element consists for the most part in ornate and minute description of actual angling, something for which we search in vain among the classic examples of the species. "Les Pescheries" fairly bristles with Ronsardian epithets

${ }^{10}$ Jodelle ed. 1670 ("La Pleiade Fr." Lemerre, pp. 334-a poem on Binet). For Binet see "Quelques Autres diverses Poesies de $\mathrm{Cl}$. Binet," Paris, I573. 
and effects, and may almost be called a fisher corruption of Ronsard.

Another evidence of the occasional occurrence of fisher pastorals in the latter part of the sixteenth century in France is a translation of Ongaro's "Alceo," 71 and a second version appeared in the seventeenth century. All these French pieces, however, were of scarcely more than casual importance in the imitation of the classics urged by the Pleiade, and were probably unknown to the English eclogue writers, whose works were not influenced by them. Like the Spanish, Italian and at a later date, German imitations of Sannazaro, they serve simply to illustrate the wide diffusion of the "new style" in renaissance Europe.

It is worthy of mention, too, that fishing appears an occasional occupation of shepherds in nearly all the most famous pastorals from the time of Theocritus to that of Queen Elizabeth. In most cases we are reminded of the gentle craft by mere casual allusion, and it would be easy to cite many passages similar to one that is to be found in Bonarelli's drama Filli Di Sciro, when old Melisso, suspecting a plot against his supposed daughter Cloris, says to her:

"I with my Hooks and Nets, will towards the Sea, Direct my steps, pretending there to fish, And so shall spie which way the Thracians tend.",72

"By Roland Brisset, Paris, 1596. Another by Claude le Villain, Paris, 1602.

${ }^{72}$ Act I., Scene 2. Translation by J. S. (Jonathan Sidnam). London, 1655 . 
Discussion of such scattered bits would not be at all worth while, but at least one pastoral is to be found illustrating an actual blending of the piscatory with the bucolic motive, and this is one of Alexander Hardie's early dramatic idylls, Alcée, published at Paris in I624. This work has been considered $^{i 3}$ as in no essential different from the author's pastoral Corine, and as of purely Italian inspiration, one more example of the persistence of the form rendered popular by Tasso's Amyntas. It is true, nevertheless, that it belongs in part to the line of successors to the idyll of the two old fishermen by Theocritus, while the title suggests the possible influence of Ongaro's Alceo. Phedime, Hardie's old fisher, lives a life of harsh and fruitless labor on the sea. He owns nothing but his hut, his skiff, and nets, and his only comforts are his daughter Alcée and Démocle, an adopted son, whom he found in a cradle cast ashore by the waves. This side of the picture is typical of the piscatory genre, but the plot varies little from those of the Italian pastoral plays.

Démocle assists Phedime with the nets and oars; in good time the young couple fall in love, and eventually are betrothed. Then the rich shepherd Dorylas offers Phedime enough money to enable him to give up his toilsome life in return for the hand of Alcée. A witch tries magic against the girl, there is an elopement which fails, the young fisher is saved from leaping from a

${ }^{73}$ La Pastoral Dramatique en France. Jules Marsan. Paris, 1905. 
rock by an echo and Cupid, and finally, just when he faces banishment, the wealthy Lygdame recognizes him as his son. The churlish fisher, of course, now allows Alcée to marry as she wishes, a conclusion which, with the naive simplicity with which the play presents the growth of love in the hearts of the girl and boy, harks back to Daphnis and Chloe.

It may safely be assumed that in France, as in Italy, the occupation of fishers was considered as specially sanctioned by holy writ, and some few pictures were probably inspired by this feeling. Thus in Saint-Amant's epic Moyse Sauvé ${ }^{74}$ we find in the dialogue of the fishermen a sort of sacred piscatory eclogue, and the same thing is true of Jean Michel's Mystere ${ }^{75}$ de la Passion, in which the biblical fishers, St. Andrew and St. Peter, figure in a fishing scene. We shall find this same sort of scene, evidently based on the Bible, of considerable influence in England at a later date.

In "La Plainte du Pécheur" "ז6 (headed Fenestra vascia-Naples) we find an isolated example of a French fisher poem based directly on imitation of the characteristics of the Italian piscatory eclogue of extravagant lament. As a rule, however, later illustrations of fisher poetry in France have apparently little if any connection with the

${ }^{74}$ I 653.

${ }^{75}$ Mystere de la Passion avec les additions et corrections de Maistre Jean Michel. Late fifteenth century (an elaboration of a work done by Arnoul Greban ante 1456).

"See A. Brizeus, "Les Ternaires," Livre Lyrique. Paris, I $84 \mathrm{I}$. 
species as it was written in the time of the Pleiade. Thus the Jesuit Jacob Vanieri ${ }^{77}$ gives a vivid picture of fishing with the rod in the fifteenth book of his Praedium Rusticum, a treatise on fish, and another somewhat similar illustration is to be found in Franciscus Champion's "Stagna,"78 a poem in Latin hexameter on fish ponds and fish. Idyllic pictures of fishers are to be observed here and there, notably in Jacques De Lille's ${ }^{79}$ L'Homme des Champs." The poem shows obvious traces of the influence of Thomson's "Seasons," and among the long list of figures described it is not surprising to find an angler, rod in hand, motionless and silent under the cool willows which overhang the stream in which he is fishing.

The piscatory motive is even used as subject for debate ${ }^{80}$ in the Disputatio de Piscatura Harengorum in Roslagia: respondente Nils Humbli, and in one of the Colloquia familiaria ${ }^{81}$ by the Dutch scholar, Desiderius Erasmus (I53r).

Another sporadic example of the recurrence of the piscatory motive is seen in the longing for the simple life of a deep-sea fisher expressed in Lamennais' Une Voix de Prison. ${ }^{82}$ Finally a single eclogue by Jacques de Fonteny, "Iolas," recalls by its title and general tone the piscatories of Sannazaro.

${ }^{77}$ Tolossae, 1730, and many later editions.

${ }^{78}$ See treatise by A. Campaux.

70 Jacques DeLille, Oeuvres, Paris, I 824.

${ }^{80}$ By N. Frondius, Upsal, 1745.

81 Venatio. See Colloquia familiaria, Leipsig, 1713.

${ }^{82}$ Lamennais, Oeuvres, Paris, 1844. 


\section{CHAPTER III}

\section{The English Fisher Idylls}

Long before exotic pastoralism blossomed in renaissance England, native tradition not unconnected with that on the continent existed in the shepherd plays of the Nativity, and in such ballads as treated the story of the wandering knight who made love to the shepherdess, a motive common at an early date, and twice used by Chaucer. This native tradition, too, was not without points of contact with the later literary species in England.

The case was otherwise with piscatory poetry. English literature previous to the Elizabethan period included no variety of poetry or prose devoted particularly to fisher-folk, and furnished no tradition of indigenous lyrics sung by fishers, though of course some slight precedent for the introduction of the piscatory pastoral existed from very remote times.

In England, as on the continent, imitation of Sannazaro began with neo-Latin pieces, from which it afterwards passed into the vernacular, and though these earlier verses have been forgotten, they can not reasonably be neglected in a history of the pastoral of the seashore. Two eclogues by Giles Fletcher the elder, probably composed before his graduation from Cambridge 
in 1569 , combine imitation of $\mathrm{Virgil}^{1}$ with the introduction of Sannazarian names, and other touches suggestive of Sannazaro's poems, and with marked emphasis on fishing. In one piece the shepherd Aegon goes angling, and chances to hear along a river's banks the shouted incantations of forsaken Telethusa. The other pastoral describes a stream near the cot of Thestylus, a swain whose poverty often forces him to rely on his rod for food. This is followed by a picture of the man, sitting at the water's edge, with his dog crouching beside him, and holding in his hand a rod of cane, to the nodding tip of which is attached a line, equipped with hooks and a cork. Having cast he is watching the float, bobbing on the water, when a friend comes along and they fall into a conversation, dealing allegorically with the tyranny of a noble, once cruel to shepherds (churchmen and poets), whose tomb now lies covered by brambles. The scene described is exactly like that which the poet often saw in his native Kent, and in view of the facts that Fletcher's son Phineas admired these eclogues and wrote Latin piscatories, perhaps in emulation, it is fair to class them as connecting links between the Sannazarian pastoral and the English imitations.

Not very long after Fletcher wrote these idylls, masques of sea-gods were introduced in court pageantry, and the presentation of such shows

1 The influence of Mantuan is also noticeable in these, and in another, "Myrtilus," in which that swain bewails the "general neglect of shepherd life." Myrtilus is the poet, and "Celadon" (cf. Sannazaro) is a friend. 
evidently paved the way for the later fisher play, just as masques of shepherds did for the better known pastoral drama. Almost the earliest of the sort extant are among "The Princely Pleasures at Kenilworth Castle,", given for the entertainment of Queen Elizabeth in 1575, one of which, "The deliverie of the Lady of the Lake," may be cited as a typical marine masque:

"Tryton, in likenesse of a mermaide, came towards the Queene's Majestie as she passed over the bridge, returning from hunting: and to her declared, that Neptune had sent him to her Highnes, to declare the woeful distresse wherein the poore Ladie of the Lake did remaine, the cause whereof was this. Sir Bruse sauns pitie, in revenge of his cosen Merlyne the prophet, whom for his inordinate lust she had inclosed in a rocke, did continuallie pursue the Ladie of the Lake; and had (long sithens) surprized her, but that Neptune, pitying her distresse, had envyroned her with waves. Whereupon she was enforced to live alwaies in that Poole, and was thereby called the Lady of the Lake. Furthermore affirming, that by Merlynes prophecie, it seemed she coulde never be delivered but by the presence of a better maide than herselfe. Wherefore Neptune had sent him right humbly to beseech her Majestie, that she would no more but shew herselfe, and it should be sufficient to make Sir Bruse withdrawe his forces. Furthermore commanding both the waves to be calme, and the

${ }^{2}$ Earlier in the year, at Killingworth castle, a very similar masque was presented. The Queen rode on a "Mermaid" eighteen feet long. 
fishes to give their attendance, and this he expressed in verse as followeth ..." (here come twenty lines of verse), and after this introduction, "The Speech of Tryton to the Queene's Majestie." Having delivered his speech-"Herewith Triton sounded his trompe, and spake to the Winds, Waters, and Fishe as followeth," the second address concluding this portion of the pageant. The Queen then went further on the bridge. The Lady of the Lake with two nymphs advanced on "heaps of bulrushes," and repeated some verses in thanks, after which "Protheus" appeared, sitting on a dolphin's back "and the dolphin was conveyed upon a boate, so that the owers seemed to be his fynnes. Within the which dolphin a consort of musicke was secretly placed, the which sounded; and Protheus, clearing his voyce sang this song of congratulation, as well in the behalfe of all the Nimphes and Gods of the Sea." This is followed by another song, eulogizing the Queen, and then "Proteus told the Queene's Majesty a pleasant tale of his deliverie, and the fishes which he had in charge." Such is a marine pageant, in this case a curious blending of the story of Merlin, in Sir Thomas Mallory's book, with the heathen gods of the ocean. Several similar pieces were performed at Kenilworth during the Queen's stay, and later this sort of masque seems to have been recognized as legitimate material for occasional presentation by itself. ${ }^{3}$ In one piece Nereus sings

'For such masques see John Nichols' Progresses, etc., of Queene Elizabeth, and of King James I. 
strains which are answered by Echo, after which Faunus and the other rustic gods present fall to fighting with their green-haired neighbors. ${ }^{4}$ Another masque included as one of the properties the figure of "Nereus holding out a golden fish in a net," with the motto "Industria."5 Still more definite indication of the conventional relationship of the ocean divinities with those who owned their sway, is found in Anthony Munday's "Chrysanaleia, or The Golden Fishing," 6 a masque which presented the usual sea-gods together with a boat full of fishers busy drawing their nets.

Such masques, we are told, were given in the Italian style, and it is not surprising, therefore, to find among the entertainments for Queen Elizabeth at Cowdray (Wednesday, Aug. 19, I59r), a fisher eclogue, which though in prose, bears all the earmarks of the species. Her Majesty was led to a pond where she heard an angler uttering a soliloquy on the deceptive baits by which city merchants decoyed the simple, on his own ill luck, and on the obvious presence of something "over beautiful," which like sunlight prevented the finny prey from coming to his hooks. Immediately afterwards he caught sight of the Queen, and of a fisher who was drawing his seine towards her. A dialogue ensued between the two fishers, the angler asking jocosely whether the other had caught any girls, as he well might have done, since Venus was wave-

- Vol. 3, pp. i rog (year i 59r).

- Vol. 2 (James), 1610, pp. 348.

- Vol. 3, James, pp. 195 (year 1616). 
born. After this banter he made a speech to the Queen, declaring the humble honesty of his trade, and concluding by laying at her feet "all the fish of the pond," in the net. This eclogue contains frequent puns, such as play on the words "carp" and "carpers," and other traits suggestive of the euphuism fashionable at the time, evidenced by balanced and antithetical sentences, with allusions to "natural history" of the sort so familiar in Lyly's works. In spite of these touches, however, the spirit of the piece ${ }^{7}$ is identical with that of the conventional fisher panegyrics already considered.

Similar use of sea mythology appears also in pastoral plays. In Lyly's " Galatea," for instance, Neptune rouses a flood, and comes near being propitiated by the offer of a maiden to be devoured by one of his sea-monsters. Again, in "Love's Metamorphosis" (I 588-9), 8 Lyly represents a husbandman, Erisichthon, as being pun-

'For an account of the entertainments at Killingworth see Nichols, Vol. I., pp. 457. Similar marine masques are found on pp. II9 (year I59I), pp. I20 (year I59I), pp. 309 (year 1594), pp. 366 (year 1594), and under James, Vol. 3 (James), pp. 618. Entertainment of the Princess at Heidelberg. See also Vol. 4 (James), "The Tryumphs of Peace" (1620). For other marine masques see Beaumont and Fletcher's "Maid's Tragedy" and "The False One"; Ben Jonson, "Neptune's Triumph," I624, and "The Fortunate Isles," 1626.

${ }^{8}$ I581, "A Shadow of Sannazar" is recorded on the Stationers' register. What this was has not been discovered. Several eclogues are offshoots of the same motive-Giles Fletcher translated Lucian's dialogue between two sea-nymphs, Doris and Galatea, concerning Polyphemus. At about the same time (1588) appeared an anonymous translation of Theocritus' idyll of Polyphemus and Galatea with five others, etc. 
ished for a crime by consuming hunger, which he can not satisfy. At length he is so hard pressed for money that he sells his daughter, Protea, to a merchant. The latter is about to set sail when the girl prays to Neptune, whose paramour she has been, and in the nick of time the god changes her into an old fisherman. In this form, after some adventures she returns to Arcadia, where she finds Petulius, her lover, being courted by a mermaid, with a looking-glass in her hands, coquetting in the waves near shore. Changing into the ghost of Ulysses, she warns the youth to avoid the "syren," and eventually Ceres ends all happily by abolishing the plague of hunger. ${ }^{9}$

Such association of the fisher with the conventions of marine mythology is well illustrated by Spenser's "Faerie Queene."10 In one passage Guyon, rowed over sea by a boatman, ${ }^{11}$ encounters all the most frightful monsters of the deep which Neptune can summon against him. In another place the poet describes the sea-king watching the mother of the slain Marinell hastening to the place where her son's body lies on the strand: $:^{12}$

"Great Neptune stoode amazed at their sight Whiles on his broad rownd backe they softly slid,

${ }^{\circ}$ It is interesting to remark that while staying with Drummond of Hawthornden Ben Jonson contemplated writing a piscatory drama in which the characters were to have been Scotch fishers on the shores of a Scotch lake.

${ }^{10}$ Bks. I-3, comp. 1 579-89, 3-6, 89-95.

$11 \mathrm{Bk}, 2$, canto 4 .

${ }^{12} \mathrm{Bk}$. 3, canto 7, st. 27. 
And eke him selfe mournd at their mournful plight,

Yet wist not what their wailing ment; yet did,

For great compassion of their sorrow bid

His mighty waters to them buxome bee:

Eft soones the roaring billowes still abid, And all the griesly Monsters of the See

Stood gaping at their gate, and wondred them to see.

A teem of Dolphins raunged in aray

Drew the smooth charett of sad Cymoent:

They were all taught by Triton to obay

To the long raynes at her commandement:

As swift as swallowes on the waves they went, That their brode flaggy finnes no some did reare, Ne bubling rowndell they behinde them sent.

The rest, of other fishes drawen were,

Which with their finny oar the swelling sea did sheare."

These passages and many similar ones in the poem bear an obvious relationship in imagery to the masques of sea-gods, and exemplify Spenser's evident fondness for such description. Without attempting to go into any of these in detail a word more should be said here concerning the story of Marinell. Fair Florimell, who loves the unfortunate youth, flees from a monster:

"It fortuned (high God did so ordaine)

As shee arrived on the roaring shore,

In minde to leape into the mighty maine,

A little bot lay hoving her before,

In which there slept a fisher old and pore,

The whiles his nets were drying on the sand.

Into the same shee lept and with the ore 
Did thrust the shallop from the floting strand:

So safety fownd at sea which she fownd not at land."

In this skiff she drifted for hours while the weary fisher slept :

"For being fled into the fishers bote For refuge from the Monsters cruelty, Long so she on the mighty maine did flote, And with the tide drove forward carelessly; For th'ayre was milde and cleared was the skie, And all his windes Dan Aeolus did keepe From stirring up their stormy enmity,

As pittying the while the fisher did securely sleepe."

At length he awoke, and was astounded to find his boat adrift and the beautiful maiden sitting in it:

"He marveild more, and thought he yet did dreame Not well awakte; or that some extasye Assoted had his sence, or dazed was his eye."

When at length he became convinced that she was not a vision he:

... " felt in his old corage new delight

To gin awake, and stir his frosen spright:

Tho rudely askte her, how she thither came?

'Ah! (sayd she) father, I note read aright What hard misfortune brought me to this same Yet am I glad that here I now in safety ame.

- But thou, good man, sith far in sea we bee, And the great waters gin apace to swell, That now no more we can the mayn-land see, Have care, I pray, to guide the cock-bote well, 
Least worse on sea then us on land befell.'

Thereat th'old man did nought but fondly grin, And saide his boat the way could wisely tell;

But his deceiptful eyes did never lin

To looke on her faire face and marke her snowy skin."

Here we have a piscatory eclogue ${ }^{13}$ interpolated in the epic, a companion picture with the story of Calidore and Pastorell, which forms a pastoral interlude. ${ }^{15}$ It is noteworthy that Spenser did not idealize his fisher, who is painted in earthy colors appropriate to his surroundings. The "wandring bote," foul with scales and slime, is called a "filthy nest," the man himself, a "filthy wretch," and he finally makes a villainous assault on poor Florimell, who defends herself and screams for aid. Very luckily:

"It fortuned, whilest thus she stiffly strove, And the wide sea importuned long space With shrilling shrieks, Proteus abrode did rove, Along the fomy waves driving his finny drove. Proteus is Shepheard of the seas of yore, And hath the charge of Neptune's mighty heard; An aged sire with head all frory hore...

His charett swifte in hast he thither steard, Which with a teeme of scaly Phocas bownd Was drawne upon the waves that fomed him arownd."

${ }^{23}$ In Francis Sabie's “Pan's Pipe," 1595, one of the pieces is "The Fisherman's Tale," but this proves to be nothing but a blank verse rendering of Greene's " Pandosto."

Bk. 6, cantos 9, ro, Ir. 
He beat the wicked monster, dragged him behind the chariot over the waves, and finally "cast him up upon the shore," but Florimell he carried down to his hall beneath the sea. There he tried in vain to win her love, tried to frighten her by his sudden and fearful changes, and failing in all, threw her into a dungeon where she remained a prisoner for a long while. After treating of many other matters, Spenser at length returns to the story of Florimell in a later part of his poem, and then fills two entire cantos (II and I2; bk.4) with an elaborate marine, telling how Marinell was cured by the Leach of the sea-gods, "Tryphon," the same useful divinity who figures in two of Fletcher's eclogues in the character of divine healer. Marinell went seeking the lost damsel, but for a long time was baffled. Meanwhile the marriage of Thames and Medway was celebrated at Proteus' hall by a procession of all the sea-gods, river-gods, and nymphs known to classical mythology and to English poetry, the whole story concluding happily with the liberation of Florimell at the command of Neptune, to whom she had prayed, and with whom the mother of Marinell had interceded, much as Thetis does for Achilles in the Iliad.

Evidently Spenser had no admiration for the artificial singing fishermen of humanistic poems, and took far more interest in elaborating the splendor of his ocean pageantry than in describing the old man, whom he deliberately makes low and vile. At the same time this villainous fisher in the "Faerie Queene" is a disagreeably real- 
istic personage, and may well have been sketched from nature, so that perhaps we should look upon his traits as a correction of the fancy pictures of the Italian genre.

We come now to the poetry of Phineas Fletcher, the most conspicuous writer of fisher idylls in England. In view of what has been said about English antecedents of his works, it may be interesting to note some of his sayings about his predecessors in pastoral literature. He calls Virgil the "Arcadian Shepherd," greater than Homer, who gladly changed the tongue in which Troy's story was told- " at the second time twice better sung." Secondly he praises Sannazaro:

10 " And now of late th' Italian fisher-swain

Sits on the shore to watch his trembling line, There teaches rocks and prouder seas to plain By Nesis fair, and fairer Mergiline:

Whilst his thin net upon his oars entwin'd, With wanton strife catches the sun and wind;

Which still do slip away, and still remain behind."

In still another place he declares :

${ }_{17}$ " Two shepherds most I love, and do adore, That Mantuan swain, who chang'd his slender reed,

To th' shrill trumpet's voice, and war's loud roar,

From Corydon to Turnus daring deed;

And next our home-bred Colin, us inspiring

10 "The Purple Island" Canto $I$, sts. I I-I5.

${ }^{17} \mathrm{Ec}$. 6, sts. $5 \mathrm{I}$ and 58 . In Pisc. ec. $\mathrm{I}$, he expresses admiration for his father's Latin pieces, and there are many other passages in which he praises Spenser. 
Their steps not following close, but far, admiring:

To lackey one of these, is all my pride's aspiring!"

One of these "swains" he did "lackey" so faithfully as to earn the appellation "The Spenser of his age," but at the same time he chose to retain the Sannazarian fisher conventions. By I603, a year before graduating from Cambridge, Fletcher was known as the author of Latin poems, among them, presumably, two early piscatory eclogues. In one the scene is a haven with caverns sheltered from the ocean by beetling cliffs, unmistakably suggestive of those about the bay in Africa where Aeneas landed after the tempest. There Myrtilus had come, bewailing his unrequited affection, and lay flat in the green sedge by his skiff, while throngs of pitying nereids strove to soothe his violent grief. His reproaches, sung to Daphne, are imitated almost line for line from Sannazaro's "Galatea," and occasional bits are borrowed from his other eclogues. Two touches not found in Sannazaro may have been suggested by Bernardes' "The Fisher's Lament." In the Spanish eclogue, ${ }^{10}$ as in Fletcher's, the singer lies beside his dory, and in both pieces the singers tell how the force of their desperate love caused them to tumble into the sea, from which they were rescued by dolphins that had been charmed by their sweet voices. Such resemblances may be coincidental, but it is

${ }^{10}$ Camões' and Bernarde's poems were often published together as by Camões. 
at least significant that Fletcher's other Latin fisher eclogue is strikingly like Camões' "Song Contest," both poems being trials of skill held before admiring fisher girls and shepherdesses, and the songs in both presenting, side by side, imitation of Virgil's singing match with that by Sannazaro. That Fletcher was enough of a linguist to read Camões is of course beyond doubt, for like his father, he was a distinguished scholar.

The exact dates of composition remain uncertain, but the English eclogues were written after I6ro, and we may safely assign the Latin to an earlier period. This strikes the reader as probable when he observes that the Latin pieces follow their sources with the close manner of imitation usual in a writer's early poems, and that in some cases the English eclogues embody elaborations of the Latin. Moreover, it can be shown that the Latin pastorals were written before the English, by an examination of these verses addressed by Fletcher to a friend:

"To my beloved Thenot in answer of his verse." But if my Thenot love my humble vein, Too lowly vein-ne'er let him Colin call me; $\mathrm{He}$, while he was, was (ah!) the choicest swain, That ever grac'd a reed: what e're befall me, Or Myrtil,-so 'fore Fusca fair did thrall me, Most was I knowne-or now poore Thyrsil name me,

Thirsil, for so my Fusca pleases frame me."

Evidently the friend, to flatter the poet, has called him "Colin" (i.e., Spenser). He replies that he is unworthy the name, and that he has given up 
his earlier appellation, "Myrtilus," from which it appears that the "Myrtilus" of the two Latin piscatories is the poet himself. A third Latin piece, later expanded in two of the English piscatories, is called "Fusca Ecloga," and in this the poet, calling himself "Thyrsilis," sings of his love for the maiden, "Fusca." This shows that the two Latin poems were written earlier than the "Fusca," and as in the English poems and in the "Purple Island" the poet styles himself "Thyrsilis," it is safe to assume that they are of later composition. Whatever the exact dates of composition may have been, Fletcher's Latin

${ }^{21}$ His brother Giles calls him "The Kentish Lad, young Thyrsilis," in "Christ's Victorie" (pub. 1610). Phineas also styles himself Thyrsilis in "To Mr. Jo. Tomkins," "To Thomalin," and "To Master W. C." (Wm. Courthope?). In the latter poem Phineas writes from Cambridge urging his friend to return from Little Haddam, where he has been too much taken up with "the nymphs." At Cambridge he says they may hear "the Mantuan shepherd's complaint of Alexis, or Thyrsil's moan, and Fusca's cruelty:

"Fusca his care, but careless enemie:

Hope oft he sees shine in her humble eye."

Probably these poems were composed before 1610 , and the English piscatories were begun shortly after that date. At any rate the Fusca affair has been replaced by another more serious in the English piscatories, and the second of these eclogues mentions the death of Phineas' father, which occurred in 1610 , as a recent occurrence.

From matter contained in the dedication of the Purple Island to Edward Benlowes it is certain that it was Fletcher's last work. In it he calls his earlier poems " raw essays of my very unripe years, and almost childhood," yet the "Purple Island" must have been begun, at least, not long after 1610, since it praises "Christ's Victorie" as a work just completed, and that poem appeared in 1610. 
eclogues were the work of his apprentice hand, written under the influence of Virgil and Sannazaro, and flung carelessly aside to give place to the English "Piscatorie Eclogs," 22 a poem so closely imitated from Spenser's Shepherds Calender that it may almost be called a fisher adaptation of the first great English pastoral.

Fletcher's calendar is a hybrid form, bearing much the same relationship to Spenser's poetry as Sannazaro's pastorals do to Virgil's. In all the piscatories imagery, settings and general conventions are borrowed directly from Sannazaro, wherever such borrowing makes it feasible for the poet to imitate Spenserian effects in their equivalent marine phraseology. This method is consistently followed throughout, just as we have seen it done in Sannazaro's imitations of Virgil.

It is not difficult to account for such fondness for the conventions of fisher pastoral. In his "Angler" Izaak Walton declares that Fletcher was a skillful angler and a very pious man, and it is likely that he was actuated by the old feeling that fishing is a godly craft. At any rate there can be no question that he adopted the piscatory form largely because of its adaptability to religious allegory of a type constantly stressed in his eclogues, and well illustrated by the following lines from his "Apollyonists":

“Those fisher-swaynes, whom by full Jordan's wave The Sea's great Soveraigne His art had taught, To still loud stormes when winds and waters rave, To sink their laden boats with heavenly fraught; To free the fish with nets, with hooks to save:

${ }^{22}$ Pub. London, 1633 . 
For while the fish they catch, themselves were caught:

And as the scaly nation they invade,

Were snar'd themselves. Ah! much more blessed trade

That of free fisher-swaines were captive fishes made!"

This conception of the sacred character of fishing derived from the Bible, and apparently of some influence in Italian and French piscatory literature, finds its most concrete expression in the debate between an angler, a huntsman and a falconer which forms the introduction to Izaak Walton's famous book. The angler's argument is too long to quote here in full, but it is largely supported by Holy Writ. "It is observable," says Piscator, "that it was our Saviour's will, that these our four Fishermen should have a priority of nomination in the catalogue of his Twelve Apostles, . . . as namely, first St. Peter, St. Andrew, St. James, and St. John, and then the rest in their order." Again, "It is to be believed that all the other Apostles, after they betook themselves to follow Christ, betook themselves to be Fishermen too; for it is certain that the greater number of them were found together by Jesus after his Resurrection, as it is recorded in the twenty-first chapter of St. John's Gospel, $5,3,4$."

As we find both Fletcher and Milton influenced by such scenes ${ }^{23}$ from the Bible, it may be well

${ }^{23}$ For this conception of the sacred nature of fishing see also O. F. Emerson. "Some of Chaucer's Lines on the Monk," Mod. Phil., vol. I., 1903-4, pp. 105. See also "The Golden Fishing" in John Nichols" "The Progresses of Queen Elizabeth and of King James." 
to quote here a part of the passage referred to by Walton, which runs as follows:

"After these things Jesus shewed himself again to the disciples at the sea of Tiberias; and on this wise shewed he himself. There were together Simon Peter, and Thomas called Didymus, and Nathaniel of Cana in Galilee, and the sons of Zebedee, and two other of his disciples.

Simon Peter saith unto them, I go a fishing. They say unto him, We also go with thee. They went forth, and entered into a ship immediately; and that night they caught nothing. But when the morning was come, Jesus stood on the shore; but the disciples knew not that it was Jesus. Then Jesus saith unto them, Children have ye any meat? They answered him, No. And he said unto them, Cast the net on the right side of the ship, and ye shall find. They cast therefore, and now they were not able to draw it for the multitude of fishes. Therefore that disciple whom Jesus loved saith unto Peter, It is the Lord.

Now when Simon Peter heard that it was the Lord, he girt his fisher's coat unto him (for he was naked), and did cast himself into the sea. And the other disciples came in a little ship (for they were not far from land, but as it were two hundred cubits), dragging the net with fishes. As soon as they saw they were come to land they saw a fire of coals there, and fish laid thereon, and bread.

Jesus saith unto them, Bring of the fish which you have now caught. Simon Peter went up, and drew the net to land full of great fishes, a hundred and fifty and three: and for all there were so many, yet was not the net broken. Jesus saith unto them, Come and dine. And none of the disciples durst ask him Who art thou? knowing it was the Lord. 
There can be no question that this idyllic picture excels in simplicity even the analogous ones in the poems of Theocritus. Christ as Shepherd figures largely in the symbolism of renaissance pastoral tradition; in Fletcher's poetry and in Milton's we find a companion figure, Christ the fisherman.

It should be remembered, also, that simultaneous imitation of Spenser and of Sannazaro did not appear at all a complex matter to Fletcher, and he may have been encouraged in the conception by the fact that some characteristics of the famous humanist's piscatories resemble those of the Shepherds Calender. In both works there is an undertone of sorrow due to unrequited love, and to disappointed ambition, that gives a slight autobiographical unity to the poems, and as it were, pitches all in a minor key. Both poets followed the Virgilian types of song, both composed panegyrics of royal personages, and both were eminently patriotic.

Turning now to the English piscatory calendar we find that just as in Spenser's work cach poem stands for a month. Fletcher begins with "Halcyon Days" (the winter solstice, Dec. 15-29) as forming a fitting commencement to the fisher year:

"It was the time when faithful Halcyone, Once more enjoying new-liv'd Ceyx' bed, Had left her young birds to the wavering Sea, Bidding him calm his proud white-curled head, And change his mountains to a champian lea; The time when gentle Flora's lover reigns, Soft creeping all along green Neptunes smoothest plains." 
The poems are not, as in their model, actually named for months, but in every one the seasonal advance is more or less definitely indicated by a descriptive passage.

The subject matter of Spenser's Calender is freely borrowed by Fletcher. Spenser's Puritan leanings, evidenced by his strictures against high prelates in the May and September eclogues, and those directed against proud and ambitious pastors, with commendation of good ones in the July, were particularly acceptable to his disciple. All these motives find their expression in a conversation between two of Fletcher's fishermen (Eclogue IV) and thus the materials of Mantuan's eclogues, on which Spenser had drawn, first found their way into the English piscatory. ${ }^{24}$ Spenser's eclogues of moral or religious satire, however, are but loosely connected with the general scheme, and exemplify the poet's most labored efforts to employ archaic diction, while Fletcher's criticisms are put into the mouths of his own father (Thelgon $^{25}$ ) and of a friend (Chromis ${ }^{26}$ ). As Thelgon's troubles form the burden of two other poems, it will be seen that the poet makes no attempt to set this religious eclogue apart, and its vocabulary and metre are not distinctive, as in Spenser. Since almost every line in Fletcher's poetry is phrased in the Spenserian manner, a few quotations will suffice to give the general effect of his poem. Thelgon rebukes Chromis

\footnotetext{
${ }^{24}$ July, cf. Mantuan 7, 8, and September Mantuan 9.

${ }^{25}$ Sann., 5.

${ }^{28}$ Sann., 3.
} 
for grieving at being surrounded by the same evil conditions that Christ had to face, reminding him that "The Prince of fishers thousand tortures rent," just as in the July eclogue of Spenser's Calender Thomalin tells Morrell that Christ, "A shepherd great," saved his "flocke . . . with shepherd great":

". . bought his flocke so deare,

And then did save with bloudy sweat

From Wolves that would them teare."

In like manner Spenser's Thomalin recalls the piety of the shepherds of old, and contrasts it with the impiety of his day, a passage adapted in these words of the fisher Thelgon:

"Chromis, how many fishers dost thou know That rule their boats and use their nets aright? That neither winde nor time nor tide, foreslow? Such some have been but (ah!) by tempests' spite

Their boats are lost; while we may sit and moan, That few were such, and now those few are none."

"Instead of these a crue of idle grooms, Idle and bold, that never saw the Seas, Fearlesse succeed, and fill their empty rooms"

"Some stretching in their boats, supinely sleep, Seasons in vaine recall'd, and windes neglecting: Others their hooks and baits in poison steep, Neptune himself with dreadful drugges infecting The fish their life and death together drink, And dead pollute the seas with venom'd stink.

Some teach to work, but have no hands to row: Some will be eyes, but have no light to see: Some will be guides, but have no feet to go: 
Some deaf, yet eares; some dumbe, yet tongues will be:

Dumbe, deafe, lame, blinde, and maim'd; yet fishers all:

Fit for no use, but store an hospital."

This entire invective was later paraphrased by Fletcher in his "Apollyonists," and just as Milton's "Paradise Lost" shows traces of the influence of this work, it can hardly be doubted that the noble lines in Lycidas on the corruption of the clergy owe suggestions to the imagery of Fletcher's epic. For instance, evil fishers "steal" into the ship by night, know nothing of the use of the "hook," are blind, and care for nothing but their own gain. Moreover, both the sheep in Lycidas and the fish in the "Apollyonists" are poisoned by the bad ministration that they receive; both rot, and both spread contagion. Yet though Milton may have borrowed a hint or so from Fletcher, he was far too fond of the orthodox in pastoralism to think of adopting the piscatory form, and he may well have smiled at lines like this-" "Some snorting in their hulks supinely sleep." Neither he nor Spenser attempted such open attacks on the clergy as Fletcher's words on the Pope as the "Fisher," who by Tiber's banks:

$$
\text { ". . . casts to enlarge his See }
$$

His ship-even then too great-with stollen plankes Length'ning, he makes a monstrous argosie"-

lines which served to embroil the poet in a religious controversy, almost at once.

Though Fletcher wrote this theological poem 
with much zest, he stated elsewhere that he loved best in Virgil Corydon's song, and in Spenser's pastorals, the lament of Colin at fair Rosalind's cruelty (Jan. Ec.), adding :

"Well may I after look, but follow all in vain."

He made an attempt to "follow" in three of his eclogues, February, April, and May. Under guise of the fisher Myrtilus the poet utters a complaint to heartless Coelia, obviously modeled on Colin's. The swain-"A shepeheards boye, (no better doe him call,)" begins with this apostrophe:

"Ye Gods of love, that pitie lovers payne,

(If any gods the paine of lovers pitie)

Looke from above, where you in joyes remaine, And bowe your eares unto my dolefull dittie: And, Pan, thou shepheards God that once didst love,

Pitie the paines that thou thyself didst prove."

Myrtilus, "A Fisher-lad" (no higher dares he look), commences his plaint in these words:

"You sea-born maids that in the Ocean reigne, (If in your courts is known Love's matchlesse power,)

Kindling his fire in your cold watry bower Learn by your own to pitie others paine, Tryphon, that knowst a thousand herbs in vain, But know'st not one to cure a love-sick heart, See here a wound that farre outgoes thy art."

It will be observed that in the piscatory Fletcher retains even the parentheses of his model. The swain sees in the dreary aspect of nature the reflection of his sufferings: 
"Thou barrein ground, whome winters wrath hath wasted,

Art made a myrrhour to behold my plight:

Whilome thy fresh spring flowrd, and after hasted Thy sommer prowde, with Daffadillies dight;"

Exactly the same sort of figure is found in the fisher's exclamation:

"How well, fair Thetis, in thy glass I see,

As in a crystal, all my raging pains!

Late thy green fields slept in their even plains, While smiling heav'ns spread round a canopie."

Colin's apostrophe to the trees with its touch of pathetic fallacy:

"You naked trees, whose shady leaves are lost, Wherein the byrds were wont to build their bowre, And now are clothed with mosse and hoary frost, Instede of bloosmes, wherewith your buds did flowre;

I see your teares that from your boughes doe raine,

Whose drops in drery Ysicles remaine ..."

finds a parallel in Myrtilus' apostrophe to the seas :

"Your stately Seas (perhaps with Love's fire) glow,

And over-seeth their banks with springing tide; Mustring their white-plum'd waves with lordly pride,

They soon retire, and lay their curl'd heads low;

So sinking in themselves they backward go.

But in my breast full seas of grief remain,

Which ever flow and never ebbe again." 
Colin says of his own heart:

"Such rage as winters reigneth in my heart, My life-blood friesing with unkindly cold."-

a passage rendered by the fisherman:

"Such cruel stormes my restless heart command:

Late thousand joyes securely lodged there."

From this point on the parallel ceases to hold, Fletcher elaborating the themes of his misery, of Coelia's beauty, and of her skill in singing. A touch borrowed from the earlier Latin "Myrtilus" is the fisher's declaration that he does not dare leap into the sea to cure his love for fear the flames of his passion may fire the deep. At the end of the song Myrtilus fainted-" So down he swooning sinks; nor can remove," just as we read of Colin-" "So broke his oaten pipe, and downe dyd lye."

Fletcher's second love poem, the April eclogue, is not closely imitated from the Calender, but forms a companion piece with Spenser's June, in which Colin tells Hobbinoll his ill fortune in love, and is comforted by him. Just so a fisher confides his feelings to a friend, and the opening lines show that the idyll is autobiographical, and that it was probably finished after the poet left the university, about $1616:^{27}$

"The well known fisher-boy, that late his name, And place, and (ah for pity!) mirth had changed; Which from the Muses' spring and Churlish Chame

${ }^{27}$ See also ec. 6 for same idea. 
Was fled, (his glory late, but now his shame:

For he with spite the gentle boy estranged)

Now 'long the Trent with his new-fellows ranged:

There Damon (friendly Damon) met the boy,

Where lordly Trent kisses the Darwin coy,

Bathing his liquid streams in lovers' meeting joy."

"Algon," for so Fletcher now styles himself, describes his symptoms, and Damon immediately diagnoses the case as one of love, just as happens in the Latin "Fusca Ecloga." Then the fisher girl Nicaea appears, armed with hook and line, and rowing in a skiff. Algon's evident confusion shows Damon that she is the cause of the trouble, and so he accosts her, and begins to plead for Algon, whereupon that youth, plucking up heart, also urges his suit. A subtile debate follows, but eventually the damsel is persuaded to grant her love to the suffering fisher, a successful conclusion that affords a striking contrast with Colin's quiet despair.

The remaining idyll of love, the May, evidently records how Fletcher's friend Tomkins, later organist of St. Paul's, confided to him an affair which he had at college. In piscatory terms:

"A fisher-Boy that never knew his peer In daintie songs-the gentle Thomalin, With folded arms, deep sighs, and heavy cheer Where hundred Nymphs, and hundred Muses inne Sunk down by Chamus brinks; with him his deare, Deare Thyrsil lay ...."

Thyrsil urges Thomalin to tell the cause of his sorrow, while: 
"Under a sprouting vine they carelesse lie, Whose tender leaves bit with the Eastern blast, But now were born, and now begin to die."

The afflicted fisher replies:

"Thyrsil, my joyous Spring is blasted quite, And Winter-storms prevent the Summer's ray: All as this vine, whose green the Eastern spite Hath di'd to black, his catching arms decay, And letting go their hold for want of might, Mar'l Winter comes so soon, in first of May."

Then Thomalin enumerates the emotions which he has felt ever since seeing " fair Melite dancing on the golden sand," and Thyrsil, just as does Damon in the preceding poem, at once declares that his friend is a victim of the gentle passion, remarking:

"Thomalin, too well those bitter-sweets I know, Since fair Nicaea bred my pleasing smart."

He then proceeds to reason with his friend, trying to prove that moderation in love is the desirable thing, ${ }^{28}$ and telling how Tryphon, ${ }^{29}$ leech of the sea-gods, once calmed the excess of his passion by:

"A salve of soveraigne and strange confection Nepenthe mixt with rue and herb-de-grace."

A much more striking imitation of Spenser than the last two is Fletcher's December eclogue, partly a piscatory adaptation of the same month in the Shepherds Calender. The rustic Colin

${ }^{28}$ Cf. Mantuan ec. I.

${ }^{20}$ Leech from Spenser. 
utters a complaint to $\mathrm{Pan}$ in which he gives a picture of the four seasons of his long life, with the occupations of each, the baneful effects of his ill success in love, and his final despair. Colin is of course Spenser's name for himself, and as he wrote the poem at the age of twenty-seven, the melancholy retrospect was in large part a fiction. Instead of following this affectation, Fletcher puts his complaint into the mouth of his father (the fisher "Thelgon"), who gives a melancholy account of his career. The parallel with Colin's experiences is very close in the first part of the poem, the shepherd's apostrophe to Pan being replaced by invocation of the nereids, and the pastoral sports of youth, gathering nuts, and hunting the hare or the stag, being neatly changed to spreading the sail, folding the net, or setting fish traps in the Thames near Eton. Very early Colin devoted himself to song:

"And for I was in thilke same looser yeares (Whether the Muses so wrought me from my birth, Or I too much beleeved my shepherd peeres,) Somedele ybent to song and musicks mirth."

It was the same way with Thelgon:

"And whether nature, joyn'd with art, had wrought me

Or I too much beleev'd the fishers' praise;

Or whether Phoebus self, or Muses taught me, Too much enclin'd to verse, and musick-playes;"

Flattery soon made Colin ambitious:

"'Fro thence I durst in derring-doe compare With shepheards swayne what ever fedde in field;" 
So of Thelgon:

"So that with Limnus and with Belgio

I durst to challenge all my fisher-peers."

In spite of the obvious parallel that may be traced between the poems, the allusions in Fletcher's are much more definite than those in Spenser. Thus near Eton Thelgon learned from Aquadune the art of an angler, after which he lived among fisher boys-_" That by learn'd Chamus banks did spend their youthful yeares." At Cambridge he composed the Latin eclogues which have been spoken of :

“I sang sad Telethusa's frustrate plaint,

And rustic Daphnis wrong, and magick's vain restraint:

And then appeased young Myrtilus, repining At general contempt of shepherd's life."

He speaks of his other productions, tells how he roused the jealousy of dark "Janus," and finally was taken by a "shepherd great" to the court of Elizabeth, whom he terms:

"Fair Basilissa, fairest maid among

The nymphs that white-cliffe Albion's forests grace!"

The Queen sent him on diplomatic missions to Germany, Russia, and Scotland, but some enemy gained all the credit for Thelgon's work, and even "the great Amyntas," a friend whom he loved in "Caledonia," forsook him for "Napean nymphs." The rest of the poem is a complaint addressed to Amyntas, and imitated from Colin's complaint to 
Rosalind in Spenser's January. The conclusion of Thelgon's plaint:

"So up he rose, and launch't into the deep;

Dividing with his oare the surging main,

Which dropping seem'd with teares his case to weep "-

is almost a translation of the corresponding lines at the end of Fletcher's Latin "Myrtilus" rendered as much as possible like the close of Colin's song : ${ }^{31}$

"The pensive boy, halfe in despight,

Arose, and homeward drove his sonned sheepe,

Whose hanging heads seeme his carefull case to wepe."

It should be added that Fletcher owes such seasonal description as he here employs indirectly to Marot, whose "Eglogue au Roy" was Spenser's model for the type of allegory employed.

Fletcher's January supplements Thelgon's complaint, the fisher Myrtilus, at the suggestion of Dorus, repeating the songs sung by Thyrsilis (Fletcher) to Thomalin (Tomkins) with their conversation relative to Thyrsil's leaving Cambridge. The latter repeats the story of his father's diplomatic expeditions, and tells how "Chame" twice gave him a position (a "painted boat"), and each time unjustly deprived him of it to honor "Gripus"-

"The basest and most dung-hill swain That ever drew a net or fisht in fruitfull main."

${ }^{31}$ Jan. ec. 
Now "Chame" has treated Phineas in the same outrageous manner:

"His stubborn hands my net hath broken quite:

My fish-the guerdon of my toil and pain-

He causelesse seaz'd, and with ungratefull spite Bestow'd upon a lesse deserving swain:

The cost and labour mine, his all the gain.

My boat he's broke; my oares crackt and gone: Nought ha's he left me, but my pipe alone, Which with his sadder notes may help his master moan."

In disgust he declares he will go away, and Thomalin replies:

"Ah foolish Chame! who now in Thyrsil's stead Shall chant thy praise, since Thelgon's lately dead? "

Fletcher's last lines on his father are among his best :

"Thomalin, mourn not for him: he's sweetly sleeping

In Neptune's court, whom here he sought to please, While humming rivers by his cabin creeping, Rock soft his slumbering thoughts in quiet ease."

Such elegiac passages in the piece, inspired by genuine feeling, form a fitting conclusion to the whole sad matter of Thelgon.

The last poem, "The Prize," is a song contest, not imitated from Spenser's spirited "verse-capping" August eclogue, but expanded line by line and passage by passage from the earlier Latin ${ }^{22}$ Giles died 16ro. 
"Lusus." Apparently the piece was composed later than I6I6, when Fletcher left Cambridge, if we may judge from the lines:

"Thyrsil their judge, who now's a shepherd base, But late a fisher-swain, till envious Chame Had rent his nets, and sunk his boat with shame So robbed the boyes of him, and him of all his game."

Before him are bands of fishermen, fisher maidens, shepherds, shepherdesses, and nymphs who hear Thomalin (Tomkins), champion of the seashore, contest for the prize of song with Daphnis, representing the rustics. The idyll is very elaborate $^{33}$ and strives everywhere to catch the mannerisms of Spenser. It is, however, by far the most classic in form of the entire set, since the songs of the fisherman, as in the "Lusus," are derived from Sannazaro, while the songs of the shepherd are as strictly Virgilian.

From this brief summary it may be seen that the eclogues include much the same material as the Shepherds Calender: autobiography expressed in the love lay, moral and religious satire, complaint at the neglect of poets, elegy, slurs on tyrannical nobles, and song contest. Thus in seven idylls Fletcher tried his hand at adapting all Spenser's leading motives except the fable (Feb.), the story of the shepherd boy who mistook Cupid for a bird (March), the lyric eulogy of Queen Elizabeth (April), and the dirge (November) imitated from Marot. It has been ob-

${ }^{23}$ All are longer than those in Spenser's work. 
served, however, that Fletcher manages to pay a handsome compliment to the Queen, and that his elegy on Thelgon's fate forms a substitute for Spenser's November theme, so that the work is almost a complete "Fishers Calender."

The vital difference between the two sets of poems is not one of material, but of meter and of diction. All the fisher pastorals are rendered in verse almost identical with that in Spenser's December eclogue, but though some slight variations occur, Fletcher never attempted the experimentation which is a marked characteristic of the earlier work. Aside from this matter of versification Fletcher strove to imitate all the most obvious mannerisms of his model, with one notable exception-the matter of phraseology. The vocabulary of the piscatories is Spenserian, and occasionally includes archaic terms or unusual spellings of words of the day, but this archaism is slight, as compared with that in the Calender, nor does the wording of the idylls vary to fit the themes treated, as in Spenser.

These limitations, together with the everpresent effort to express the Sannazarian conventions in the figures and words of Spenser, constituted a serious handicap, and it is no wonder that Fletcher's verse, monotonously even and sweet, never attained the higher poetical effects of his model. It follows that naturalism could hardly result from such a scheme, for thin as it is, the allegory was perhaps Fletcher's chief aim, and his characters are only Cambridge fisher boys, even less professional than those of Sannazaro. 
It will be recalled that the rather thin descriptive matter in the Shepherds Calender becomes less superficial in pieces like Colin's January complaint, where the interest is more personal than elsewhere, and the same thing is true of Fletcher's imitations. Perhaps the most striking trait in his illustrative matter is his adaptation of Sannazarian imagery to English landscapes. Thus Thelgon, in the December eclogue, sings under beetling cliffs beside the sea, but his thoughts fly to the river he knew as a youth:

"Of Aquadune I learnt to fold my net, And spread the sail, and beat the river round, And withy labyrinths in straits to set, And guide my boat, where Thames' and Isis' heire By lowly Aeton slides and Windsor proudly fair."

"There while our thinne nets dangling in the winde Hung on our oars' tips, I learnt to sing:

Among my peers, apt words to fitly binde

In numerous verse; witnesse thou crystall spring, Where all the lads were pebbles wont to finde; And you thich hasles, that on Thamis' brink Did oft with dallying boughs his silver waters drink."

In like manner the January poem begins near the ocean :

\section{Dorus}

"Myrtil, why idle sit we on the shore?

Since stormy windes, and waves' intestine spite Impatient rage of sail or bending oare; Sit we and sing, while windes and waters fight; And carol lowd of love and love's delight." 
Myrtilus suggests a more suitable theme:

"Tell we how Thyrsil late our seas forswore, When Forc't he left our Chame, and desert shore."

Dorus replies:

"Now as thou art a lad, repeat that lay; Myrtil, his songs more please my ravisht eare, Then rumbling brooks that with the pebles play, Then murmuring seas broke on the banks to heare, Or windes on rocks their whistling voices teare."

praise that sounds like the marine equivalent for Spenser's

"Colin, to heare thy rymes and roundelayes, Which thou were wont on wastfull hylls to singe, I more delight then larke in Sommer dayes: Whose Echo made the neyghbour groves to ring."

Yet almost immediately afterwards the poet turns to inland scenes, and subsequent marine illustration is limited to bits like these:

"Myrtil, fast down by silver Medwaye's shore: His dangling nets (hung on the trembling oare ${ }^{34}$ ) Had leave to play: so had his idle hook, While madding windes the madder Ocean shook. Of Chamus had he learnt to pipe and sing, And frame low ditties to his humble string."

In the same month (Feb.) after a calm:

"Late thy green fields slept in their even plains, While smiling heav'ns spread round a canopie, Now tost with blasts and civil enmitie, While whistling windes blow trumpets to their fight,

${ }^{84}$ Cf. Sann., ec. 3. 
And roaring waves, as drummes, whet on their spite."

Again, the pathetic fallacy occasionally extends to the waves:

"Your stately Seas (perhaps with Love's fire) glow,

And over-seeth their banks with springing tide;

Mustring their white-plum'd waves with lordly pride,

They soon retire, and lay their curl'd heads low;

So sinking in themselves they backward go.

But in my breast full seas of grief remain,

Which ever flow and never ebbe again."

Such are the marine glimpses, but the poet is plainly more at home

"Where lordly Trent kisses the Darwin coy,

Bathing his liquid streams in lover's meeting joy." (Ec. 5.)

Pictures like the following in the sixth piscatory eclogue suggest a tendency in the later poems to revert to the orthodox scenery for pastoral:

"The warmer sunne his bride hath newly gown'd, With firie arms clipping the wanton ground,

And gets an heav'n on earth: that primrose there, Which 'mongst those violets sheds his golden hair, Seems the sunne's little sunne, fixt in his azure sphere."

Of lambs he says

"See'st how they skip, and in their wanton pranks Bound o'er the hillocks, set in sportful ranks? They skip, they vault; full little caren they 
To make their milkie mother's bleating stay.

See'st how the salmons (water's colder nation)

Lately arriv'd from their sea-navigation,

How joy leaps in their heart, shewn by their leaping fashion?" (ec. 6).

In expressing his poetic ideals (October) Spenser, affecting to be already tired of the pastoral, as Virgil had done before him, throws aside its fiction, yearning for ideal achievement to be expressed later in the "Faerie Queene." Somewhat in the same manner the last piscatory shows Fletcher no longer a fisher, but a philosophical shepherd, perhaps looking forward to what he considered his highest attainment, imitation of Spenser's epic in the "Purple Island." 35

The uniformly serious tone of the eclogues, so different from the sly humor which colors some of the Italian marine pastorals, distinguishes them from Fletcher's "Sicelides," written for presentation before King James ${ }^{36}$ at the university (March, 1615). The lively action and interesting characterization which distinguish this play from the rather dull manner of the piscatory eclogues, may be explained in part by the nature of some productions which immediately preceded the drama. Samuel Daniel's eclogue, "Ulysses and the Siren" (published I605), may have suggested to William Browne the theme for his Inner Temple Masque (I6r4), in which the wiles of the sea-maiden and the evasions of the crafty Greek furnish much the same humorous

${ }^{85}$ In this poem the poet becomes the shepherd Thyrsilis.

so James left before it was played. 
situations treated by Calderon in his " $\mathrm{El}$ Golfo de las Sirenas." Again, as an island play, "Sicelides" belongs, topographically at least, to the same category as Nashe's "Isle of Dogs," a satirical piece acted in 1597, Day's farce (founded on Sidney's "Arcadia"), "The Isle of Gulls" (I605), and Shakespeare's "Tempest" (I6IoI6II). The farcical element in Fletcher's pastoral drama, which furnishes a light under-plot, contains touches probably inspired by the "Tempect," of which the lines descriptive of the hideous creature of the island furnish the most conspicuous example, and we may assume that Fletcher had in mind a second Caliban:

“. . Mago, (thus his hated rivall's nam'd)

All blacke and foule, most strong and ugly fram'd, Begot by Saturne on a sea-borne witch,

Resembling both; his haires like threeds of pitch, Distorted feete, and eyes suncke in his head:

His face dead pale, and seem'd but mooving lead, Yet worse within, for in his heart to dwell His mother's furies have their darkest hell."

In view of the fact that occasional Shakespearean touches can be traced in "Sicelides," it is quite possible that Fletcher found in Pericles (I607-I608) recent and ample precedent for presenting on the stage scenes depicting fisher life. The two rude old fellows of Fletcher's play seem caricatures of those described by Theocritus, but at the same time they differ so completely from their humanistic brethren as to suggest the probability that their conception was influenced by the popularity of Pericles. The sources of Shake- 
speare's drama, a novel by Laurence Twine, the "Patterne of Paineful Adventures," (1576), and the tale of Apollonius of Tyre in Gower's "Confessio Amantis," (I483), embody some of the English renderings of a story extremely popular throughout the literatures of Europe from early times, and almost certainly taken from a lost Greek romance of the Heliodorus cycle. It is significant that the idyllic picture of the existence of contented poverty led by the fishers in the Ethiopian History was imitated in other romances, ${ }^{37}$ notably in the Ephesian histories of Xenophon, whose hero, Habrokomes, is aided and entertained by a fisherman of Syracuse, and in the story of Apollonius of Tyre. The sole survivor of a shipwreck, that prince was washed ashore at Cyrene, where he met an old fisherman who took pity on his misery. This fisherman gave Apollonius some of his own garments, and told him how to reach Pentapolis, where he eventually won a game of ball in a competition before the king. ${ }^{38}$ This story changed little in ten centuries, and in Shakespeare's play the identical fisher idyll of the Greek romance is reproduced, in amplified form. Near Pentapolis, Pericles, who has been shipwrecked, is cast upon the coast, where he sees a fisher directing the work

${ }^{87}$ Rohde, “Der griechische Roman," pp. 412.

${ }^{38}$ For the various ramifications of the Apollonius story, see A. H. Smyth, "Shakespeare's Pericles and Apollonius of Tyre." For an account of the Heliodorus idyll, see chapter I. A novel based on Pericles, Geo. Wilkins' "Pericles Prince of Tyre," pub. 1608. Lillo's "Marina," a play based on acts 4 and 5, pub. in the eighteenth century. See A. H. Smyth. 
of two others at the nets. The conversation between these men, full of rude mother wit and smacking of the sea, forms part of the most realistic picture of the sort in English. At length Pericles addresses the toilers and explains his predicament. Insolent at first, they soon perceive the prince's real distress, and give him a dry gown, after which one leads him towards their humble home to stay with them, while the others run to the seines. Presently they reappear dragging a net, heavy with some mysterious object, which proves to be the rusty armor once given Pericles by his father, and in this he succeeds in winning a tournament at Pentapolis, whither he is directed by the fishers, after resting at their cabin. If, as is likely, the fisher interludes in the Greek romances are imitated from the piscatory idyll of Theocritus, in Pericles ${ }^{39}$ we find the survival of the essentials of the primitive species, in a form much less altered by time than the humanistic genre initiated in Italy by Sannazaro.

Turning now to "Sicelides," we find that it is, for the most part, a fisher adaptation of motives characterizing the ordinary pastoral drama. The fisherman Perindus is in love with the fisher maiden Glaucilla, daughter of Glaucus and Circe, and she returns his love. Fearing a threatening oracle, however, he dissembles his affection and treats the girl with apparent scorn. His sister Olinda is loved by Glaucilla's brother, the fisher

${ }^{30}$ As the Apollonius story was wide-spread the fisher episode, often in elaborate form, is found in nearly every European language. 
Thalander, but treats all his advances with a coldness distinctly reminiscent of Silvia's treatment of Amynta in the famous Italian pastoral. She even goes so far as to accept attentions from Thalander's rival, the hideous monster of the isle, and this "hag-born whelp" makes Olinda banish Thalander, and persuades her to gather Hesperian apples in a sacred grove. For this she is condemned to be chained to a reef and given to Neptune's horrible “orc," but Thalander, having returned to Sicily disguised as Atyches, slays the beast, and as reward is betrothed to Olinda, who, however, has now repented of her harshness to Thalander, and hence can not love her rescuer.

Meanwhile a very wanton nymph of Messina, Cosma, whose love affairs form marine equivalents for those of the light Corisca of Guarini's Italian "Pastor Fido," of the "Wanton Nymph of Corinth" of Arcadian casts, or again of Cloe in John Fletcher's "Faithful Shepherdess," falls in love with Perindus. Perceiving his love for Glaucilla she gives his sister poison, pretending that it is a love philtre. Glaucilla suspects the drug, and mingles with it other ingredients, so that when the girl takes the draught she does not die, but falls into a trance. Cosma, deeming the venom effective, now accuses Glaucilla of poisoning Olinda, and manages to have her condemned to be thrown from the rocks into the ocean. Perindus appears and forces the priest of Neptune to let him be hurled from the cliff, in place of Glaucilla. When he strikes the water he is rescued by two old fishermen, Scrocca and 
Cancrone, who are promptly arrested for interfering with the course of divine justice, and are condemned to be led to the mountains to be devoured by Rimbombo, a cyclops, son of famous Polyphemus.

The uncouth gallantry of the giant to Cosma recalls the Polyphemus and Galatea idylls of Theocritus. Cosma's page, Conchylio, dressed in his mistress' clothes, makes assignations with various lovers, among them with Rimbombo, whom he contrives to tie to a tree in the branches of which the fisher Cancrone is watching for his nymph, as he thinks. Cancrone leaps on Rimbombo's back and bounces to the ground. Then, Ulysses-like, he and Conchylio try to put out the eye of the giant with a staff, but the monster manages to cut his bonds, and retreats to the highlands in disgust. Another of Cosma's suitors, the lustful old fisherman Fredocaldo, who is also victimized by Conchylio, is perhaps a broad caricature of the aged scoundrel in the "Faerie Queene."

At the close of the play Olinda comes back to life, and is led to Thalander by Glaucus and Circe; the oracle is harmlessly fulfilled, the old fishers are forgiven, and finally the father of Perindus and Glaucilla, Tyrinthus, who had been captured years before by pirates, returns in time for the double wedding. As in the "Pastor Fido" and the "Faithful Shepherdess," the wicked nymph repents of her misdeeds, but in the fisher play she is made to marry Cancrone in punishment for her crimes. 
The choruses have considerable poetic merit. $\mathrm{One}^{40}$ on death is an English rendering of Fletcher's own early Latin poem, "Mors est Malum"; another is based on Ovid's version of the descent of Orpheus into the under-world; while two more are intended, apparently, for English equivalents of choruses in Tasso's Amintas, or Guarini's Pastor Fido. One of them is on love, and the other, a few stanzas of which follow, is the fisher analogue for the famous Golden Age chorus :

"Happie happie fisher-swaines,

If ye knew your happiness;

Your sport tastes sweeter by your paines,

Sure hope your labour relishes:

Your net your living, when you eate

Labour finds appetite and meat.

When the seas and tempests roare

You eyther sleepe or pipe or play,

And dance along the golden shore:

Thus you spend the night and day

Shrill windes a pipe, hoarse seas a tabor

To fit your sports or ease your labour.",

A word should be added about the portrayal of fisher folk in "Sicelides." In spite of the broad and farcical treatment of the scenes in which Scrocca and Cancrone figure, they give more local color and more realistic presentation of the life of the seashore than all of the poet's eclogues put together. They thus have more significance in the piscatory genre than the other scenes of

40 Act. I., sc. 4 .

${ }^{4}$ Act 2, sc. 7. 
the drama, which are not essentially different from those in contemporary shepherd plays, save in the pretense of a fisher life and of appropriate activities.

Unlike the eclogues the play is mainly in rimed couplets, but the language, as in most of Fletcher's poems, apes here and there the Spenserian affectation of archaic phraseology. Some of the more obvious borrowings have already been noted, but it should be noticed that occasionally the author utilizes lines from the piscatory eclogues, and that the orc story, though perhaps suggested by the Andromeda myth, or by the orc in Ariosto, may have been influenced by the more recent example of Lyly's Galatea. The crime for which Olinda was condemned was probably taken from the breaking of a tree sacred to Pan in Browne's Britannia's Pastorals, ${ }^{42}$ and from the same source were borrowed Perindus' self-sacrificing leap and the timely rescue.

As an example of the fisher variant on pastoral drama "Sicelides" occupies rather an isolated place, save for the relationship of the mythological side of the piece with the marine masques, but in "The Thracian Wonder," a pastoral play of uncertain authorship, formerly attributed to Webster and Rowley, and printed in 1661 , a lingering ${ }^{43}$ of the piscatory element in the drama is illustrated by the introduction of an old fisher-

"See W. W. Gregg, pp. 34I, "Pastoral Poetry and Pastoral Drama:"

"In Monk Lewis' play, "The Castle Spectre" (produced Londion, 1797) we find a fisherman's hut-an example of the piscatory motive in "Gothic" drama. 
man who comes to Pheander, King of Thrace, to warn him of the approach of his foes, whom he has seen coming from Sicily (Act 3, sc. I).

A little while after ${ }^{44}$ Fletcher finished his play, the Scotchman, John Leech, composed his Latin "Musae Priores,"45 including fisher and "nauttical" eclogues. In a prefatory epistle the author gives a rather unnecessary clue to his sources, asking, "Who besides Sannazarius has done piscatories, and who besides Grotius has tried 'nautical' poems?" An examination of the fisher pastorals shows that Leech aimed to do in Latin what Fletcher had done in English-namely to express the Calender motives in Sannazarian form and imagery. Accordingly, Leech's father (thinly disguised as the fisher Dorylas-ec. I) bewails the neglect of his poetry, his oppression at the hands of an undeserving rival, and his blighted youth, ending with an appeal for the tavor of the chancellor, "Setonius." Next we learn that Dorylas is lately dead (ec. 2) and Leech as "Stymichon," with a companion fisher, mourns his unjust treatment and sad death, ${ }^{48}$ just as occurs in the corresponding piece by Fletcher. Then we find Lycon (ec. 3) lamenting the general neglect of poetry and religion, and criticizing

4 Sicelides was first published 1631, in an edition teeming with misprints.

"4 Published London, 1620. In fifth "nautica" he says the poem was done "Scotia discedens, Kal. Octobris 16 1 7." 'The volume contains also eclogues of vine-dressers, elegies, epigrams, and anacreontics.

"The elegy is like Sannazaro's "Phyllis," but concludes with a song imitated from Virgil's lament for Daphnis, the singer calling on the nymphs and seagods to tell where they were when Dorylas died. 
the evil ways of powerful fishers in "great boats." Another poem (ec. 5) is a complaint by Stymichon (the poet himself), an exile from Scotland, whose boat and tackle lie on the banks of Thames. Sitting there he repeats his father's lament at being deprived of skiffs, nets and hooks by "greedy Myrilus," with other misfortunes. All this is very like Fletcher, though Leech preserves more specific Sannazarian effects, such as the refrains. A single eclogue (4) deserves special mention as the result of an effort to imitate the Theocritean idyll of Asphalion and his friend. Olpis ${ }^{47}$ is seated on a rock with Eurybaton, "the one skilled with nets, the other with hooks." 48 Their great age, their senile garrulity, and their companionship in poverty recall the Greek source, and the whole piece seems like a studied attempt to transfer the ancient fishermen to the shores of Scotland. Olpis jerks a fish from the sea, and asks what use there is in remembering youth"Old age has beset with ice the sharpness of my mind, nor can I remember-may you avail for two." The other replies that they share the same tasks, they are both aged, and their wattled cabins stand side by side, so that what pleases one can not displease the other-true friends have not different minds. This passage recalls the comrades whom Theocritus depicts-both aged, sharers in toil, sleeping in a wattled cabin, and the Greek Asphalion's "I would not have thee to go without thy share in my vision; even as we go shares in the fish we catch, so share all my

"Name from Theoc.

4s Sannazarius, fragmentum, lines I6-I7. 
dreams." But instead of telling a vision, the Scotchman gives a rambling discourse on the wonders of nature in various lands, especially the many varieties of marvelous fish, concluding with a touch of local color in picturing salmon rushing up the firths of Scotland, with the songs by which Caledonian fishermen lure them to their weirs.

It has been remarked that Leech mentions Grotius as the only poet to compose "nautical" eclogues, and it is evident that he took the humanist's word in the matter, since in a Latin idyll written for his friend Daniel Heinsius, Grotius had declared, "The stormy surges, and the sandy shores" with which his piece deals, to be "themes yet unsung." In spite of this claim, however, Grotius' poem is a very plain imitation of Sannazaro's "Galatea," given here and there a "nautical," $i$. e., deep sea touch-a type of poem, as has been shown, of common occurrence in the sixteenth century. The fisherman Myrtilus has just landed from a storm-tossed bark on the coast where "fair Cochlis" lives in a cave. His complaint at the cruelty of this nymph is in form closely modeled on the earlier Latin poem, but the singer boasts "the strains which once Arion sung," which, rather curiously, include the seafaring of Jason, Ulysses, Circe, Calypso, Nausicaa, etc. Mention of such mythical voyagers and an invitation to Cochlis to sail on his fishing vessel are the only "nautical" hints which differentiate this poem from other piscatories, with which after all it should be classed. Strictly nautical eclogues are concerned with mariners 
and not with fishers like Myrtilus, who offers Sannazarian sea-spoil as propitiatory gifts-oysters, etc.-and expresses his desire to have the girl go fishing with him in dories, "with nets and spears" for "tunnies and soles," and with "floats, hooks, and lines."

The nautical touches were what Leech was striving to emulate in his poems, and he accordingly tried to give a deep sea tone to his descriptions, at the same time imitating Sannazaro even more closely than in his piscatories. One poem modernizes the song of Arion, the sailors Emporus and Aegialeus (name from one of Alciphron's epistles) meeting on the shore near their anchored vessels, and singing alternate songs about Magellan, Vespucius, Columbus and other great explorers. The second, "Proteus," differs from Sannazaro's piece by the same name only in that the sea-god sings to his herd near a vessel on which the crew are sound asleep. Another is imitated from Sannazaro's contest, but is rendered nautical by the fact that the singers sit on the lofty stern of a ship, while the sailors are asleep. ${ }^{49}$ The last is another complaint closely resembling the "Galatea," and sung on shore by a sailor-fisherman, just as in the piece by Grotius. A saucy echo, however, is borrowed from other fields of pastoralism to mock the cries of the lovesick youth. These poems belong to humanistic rather than to English literature, and are included in this book only because they furnish rather interesting examples of Latin imitation of the

"Some parts of the poem are mere centos of Sannazaro. 
Shepherds Calender in piscatory imagery, and because they may well have been influenced by the more pretentious work of Fletcher.

The sixth nymphal in Michael Drayton's "The Muses' Elyzium," published in 1630, is the last of the fisher idylls of the Elizabethan period. That the idea of composing such a poem was suggested to him by Sannazaro's work may be inferred from a sentence in his dedication of these pastorals to Sir Walter Aston Drayton:

..." this, as all the other forms of poesy (excepting perhaps the admirable Latin piscatories of that noble Neapolitan, Sannazar) hath been received from Greece and second from Rome."

He calls his own poems pastorals in name only, and "bold upon a new strain," but he praises Spenser's Calender, and calls Spenser the prime pastoralist of England.

Superficially the nymphal bears some resemblance to Fletcher's last eclogue, being a song contest between a forester, Silvius, a fisher, Halcius, and a shepherd, Melanthus, held before the nymphs as judges. Fletcher's piece, it will be recalled, is a match between a fisher and a shepherd, before an umpire, nymphs and shepherdesses. Drayton's poem, however, is modeled on nothing but the dainty fancies of an ideal world, the culmination of a long sequence of pastoral work, ${ }^{50}$ and almost free from the fetters of the classic forms. In such a fairy sphere it is not

${ }^{\text {s0 }}$ See W. W. Greg, pp. I03 fol. 
surprising to find the nymphs, fair arbitresses, praising the songs, and at the end crowning all three singers with fresh garlands. Each youth praises his own way of life, and Halcius' song, a graceful lyric and at the same time one that offers a contrast with the strains of the fisher in Fletcher's poem, who followed the classic technique, may well be quoted here, together with a few other lines of interest. The introductory description has a lyric sweetness that forms a fitting prelude to what follows:

"Cleere had the day bin from the dawne, All chequered was the Skye, Thin clouds like scarfs of Cobweb Lawne Vayld Heaven's most glorious eye.

The Winde had no more strength then this, That leisurely it blew, To make one leafe the next to kisse, That closly by it grew.

The Rils that on the Pebbles playd, Might now be heard at will; This world they onely Musick made, Else everything was still.

The Flowers like brave embraudred Gerles, Lookt as they much desired, To see whose head with orient Pearles, Most curiously was tyred."

The swains and nymphs met on a pretty hill, where a dispute arose "who should the worthiest be," and it was arranged that it should be settled by a trial of skill. The forester sang first, and the nymphs were generous in praise, vowing to give him bays, after which the fisher began thus: 
"No Forrester, it must not be borne away,

But heare what for himself the Fisher first can say,

The Chrystall current Streames continually I keepe,

Where every Pearle-pav'd Foard, and every Bleweyd deepe

With me familiar are; when in my Boate being set,

My Oare I take in hand, my Angle and my Net."

He steers wherever he pleases, and in the waters the "silver-scaled Sholes" swarm "As thick as ye discerne the Atoms in the Beames." He likes especially near a willow-fringed bank:

"... to sheeld me from the heat,

Where chusing from my Bag, some prov'd especiall bayt,

The goodly well growne Trout I with my Angle strike,

And with my bearded Wyer I take the ravenous Pike,

Of whom when I have hould, he seldom breakes away

Though at my Lynes full length, soe long I let him play

Till by my hand I finde he well-nere wearyed be, When softly by degrees I drawe him up to me. The lusty Salmon to, I oft with Angling take, Which me above the rest most Lordly sport doth make,

Who feeling he is caught, such Frisks and bounds doth fetch,

And by his very strength my Line soe farre doth stretch, 
As drawes my floating Corcke downe to the very ground,

And wresting of my Rod, doth make my Boat turne round."

When not thus busied, he is dragging his nets, or baiting fish traps, more after the manner of Sannazarian fishermen, or even catching eels. Nor are the nymphs absent from these scenes:

"The Naijdes and Nymphes that in the Rivers Keepe,

Which take into their care, the store of every deepe,

Amongst the Flowery flags, the Bullrushes and Reed,

That of the Spawne have charge (abundantly to breed)

Well mounted upon Swans, their naked bodies lend

To my discerning eye, and on my Boate attend, And dance upon the Waves, before me (for my sake)

To th' musick the soft wind upon the Reeds doth make."

Besides these inland beings the divinities of the sea come in with every tide:

"... the roughrer Gods of Seas

From Neptunes court send in the blew Neriades, Which from the bracky Realme upon the Billowes ride."

Lastly, of course, he sings as only a fisher or a shepherd could sing:

"The silent medowes seeme delighted with my Layes, 
As sitting in my Boate I sing my Lasses praise,

Then let them that like, the Forrester up cry,

Your noble Fisher is the only man say I."

The strains of the other singers are as effective as the ones quoted, but Halcius' pictures of angling life are noteworthy as affording a glimpse at a delicately idealized realm of fancy, and at the same time as rendering a description of actual fishing which is thoroughly true to life and thoroughly English. Side by side we see the nymphs mounted on swans and the fisher engaged in playing a salmon in the most sportsmanlike manner, and angling of this sort forms a marked contrast with the thin pretense of activities kept up by the characters in earlier eclogues.

All the English poetry thus far cited is directly or indirectly related to the humanistic genre. Within regular pastoral, too, from ancient times, occasional mention is made of fishing, and in England, where angling was always popular, it was only natural that these passages should receive some touches of local color, should tend in time to receive considerable emphasis, and eventually should be rendered by themselves. Among the earliest complete poems of the sort is John Donne's ${ }^{51}$ "The Bait," composed C. 1593, a clever adaptation of Marlowe's famous pastoral, "The Passionate Shepherd to his Love":

"Come, live with me, and be my love, And we will some new pleasure prove Of golden sands, and crystal brooks, With silken lines and silver hooks.

${ }^{5}$ Published London, 1633 . 
There will the river whispering run, Warm'd by thine eyes more than the sun; And there th' enamour'd fish will stay, Begging themselves they may betray.

When thou wilt swim in that live bath, Each fish, which every channel hath, Will amorously to thee swim, Gladder to catch thee, than thou him.

If thou to be so seen be'st loth By sun or moon, thou darkenest both; And if myself have leave to see, I need not their light, having thee.

Let others freeze with angling reeds, And cut their legs with shells and weeds, Or treacherously poor fish beset, With strangling snare, or windowy net.

Let coarse bold hands from slimy nest The bedded fish in banks out-wrest, Or curious traitors, sleave-silk flies, Bewitch poor fishes' wandering eyes:

For thee, thou need'st no such deceit, For thou thyself art thine own bait, That fish that is not catch'd thereby, Alas! is wiser far than I."

Again, in John Fletcher's "Faithful Shepherdess" (I609-I6II) the satyr says:

"... when the weather

Serves to angle in the brook, I will bring a silver hook, With a rod as white as milk, And a line of finest silk To deceive the little fish. . .." 
It is to be doubted whether Walton would have approved of such fanciful tackle, which would suit better the artificial manner of Drayton's "Shepherds' Sirena," some lines of which repeat the central idea of Donne's "The Bait":
"The fishes in the flood,
When she doth angle,
For the hook strive a-good
Them to entangle;
And leaping on the land,
From the clear water,
Their scales upon the sand
Lavishly scatter."

Drayton's lines on angling are rarely so artificial as these, and his description of salmon running upstream, given in his "Polyolbion," is as accurate as can be desired, being incidentally cited as an authoritative passage by Walton in his "Compleat Angler." Similar correctness characterizes a passage of twenty-five lines in William Browne's "Britannia's Pastorals" (1613-1616), describing minutely an angler playing a large pike, and within a few years independent fishing lyrics, ballads, choruses, etc., became common. Meanwhile, after the publication of Fletcher's piscatories (I633) the exotic genre almost died out with the decay of pastoralism, not to be revived until the following century, when Walton's famous treatise became so much an object of imitation.

First published in 1653 , the "Compleat Angler" went through eight editions before the close of the century, and the piscatory poetry of 
the late seventeenth century is best illustrated by the quotations which it contains of poems by $\mathrm{Du}$ Bartas, Sir Henry Wotton, Joseph Davors, Michael Drayton, John Donne, Phineas Fletcher, Joseph Chalkhill, Walton, and many others. These verses breathe a love for the quiet, quasipastoral existence of the angler, and form part of an ever-increasing literature during this and the two following centuries. Anthologies of such poems include songs, heroics in many cantos, sonnets, meditations, etc., and libraries of fishing books often contain thousands of volumes in verse or in prose. Much of all this verse, howover, though inspired by the same enthusiasm for angling to which many writers of real merit gave expression, is the work of men who were better fishers than authors, and has no real connection with the pastoral species which we are tracing in this book excepting in the eighteenth century, when we shall find some points of contact, especially between the treatise and the eclogue.

During the late seventeenth century the fisher idyll is represented in England only by a few disconnected examples. The most interesting of these is to be found in Milton's "Paradise Regained," where Andrew and Simon, with others. after searching in vain for the Saviour who had been revealed to them:

“. . . returned in vain.

Then on the bank of Jordan, by a creek,

Where winds with reeds and osiers whispering play,

Plain fishermen (no greater men them call)

Close in a cottage low together got." 
The parenthesis recalls at once Fletcher's “A Fisher-lad (no higher dares he look)," and Spenser's "A Shepeheards boye, (no better doe him call,)" and there can be no cloubt that the idyllic picture owes its simplicity in part to the occasionally realistic tradition of fisher pastoral, though more, probably, to the ultimate source in such passages in the Bible as the following ${ }^{\mathbf{5 2}}$

I8. "And Jesus, walking by the sea of Galilee, saw two brethren, Simon called Peter, and Andrew his brother, casting a net into the sea: for they were fishers.

19. And he saith unto them, Follow me, and I will make you fishers of men.

20. And they straightway left their nets, and followed him."

Ths story, it will be remembered, seems to have been the inspiration of Fletcher's favorite allegory. No piece of the sort is complete without a lament, and like so many of the humanistic eclogues, Milton's fisher idyll voices a complaint and a prayer. The fishers:

"Their unexpected loss and plaints outbreath'd," and their words voice complaint at the disappearance of Christ, an apostrophe to the Crea-

${ }^{52}$ St. Matthew, 4, 18, 19, 20. Other picces are: Nicholas Rowe's "Glaucus and Scylla," in which the mythical fisher speaks couplets, a ridiculous dialogue between an angler and the owner of some land down stream who claims that the sportsman is muddying the water, written by William King and called "The Fisherman," and T. Ford's "Piscatio" (1692), a Latin piece which imitates Horace's "Beatus Ille" in imagery adapted to angling life, and which was five times rendered in English in the next century. 
tor, a prayer that the Messiah be given back to them, and determination to abide the divine will in quiet hope.

\section{The Eighteenth Century}

In the early eighteenth century the fisher eclogue revived, but its nature, as well as that of the regular bucolic, was modified by the attitude of the Augustan period towards pastoralism. Pope criticised severely the use of allegory and religion in Spenser's Calender, while Steele ${ }^{53}$ insisted on simplicity of manners, innocence and a mixture of piety with superstition as essential parts of shepherd character and maintained that style was the most important thing in all pastoral poetry. These writers, as was natural in an artificial period, when form was more regarded than spirit, preferred Virgil to Theocritus. By "style" and "Virgil's style," the critics of the day meant in English the sort of verse exemplified by Pope's pastorals, and by Dryden's translation of Virgil's bucolics. Of course, therefore, the meter of piscatories and shepherd songs alike became rhymed couplet.

The first fisher idyll of the period, John Whitney's "The Genteel Recreation with A Dialogue between Piscator and Corydon" appeared in I700. The "dialogue" is really a fisher poem in which the classic motives are replaced by Waltonian imagery. Occasional references to Thetis, Venus, Neptune, etc., recall vaguely the conventions of the exotic genre, but do not convince the

"Tatler, 1704, "Discourse on the Pastoral.". 
reader that Whitney had ever heard of Sannazaro. His object was obviously to produce a versified "Compleat Angler" in miniature. Accordingly Piscator and Corydon expatiate on the delights of a fisherman's life and of a herdsman's life, somewhat as do the classic shepherds and neatherds, but more after the manner of "Piscator, Venator and Auceps" at the beginning of the "Angler," and as in that treatise, Piscator persuades his hearer to watch him display the beauties of angling, while a herdsman tends his cattle. $^{54}$ A few lines will give an idea of the qualities of the verse, which to tell the truth, is not that of a poetic genius:

\section{Piscator}

"Propitious fortune bless my floating quill By which, observing how the Fishes still Nible the bait, then greedy swallow all, As dying Victims, triumph in their fall, That Corydon may see the difference and find, That pleasure soon expels the troubles of the mind."

The rest of the piece is almost an epitome of Walton's treatise. Piscator's skill and success are witnessed by Corydon, who becomes a convert to the gentle art, and invites the angler with his friends to feast on their catch, which Piscator cooks in approved Waltonian fashion. The milkmaids, Phillis and Chloris, are called on to sing, just as in that part of the "Angler" where a milkmaid sings Marlowe's "Come live with me and

${ }^{54}$ Just as occurs in Virgil's fifth bucolic. 
be my love," and her mother replies with the "Milk-maid's Mother's Answer." Whitney's lyrics sound almost ludicrous beside Marlowe's, but their enthusiasm entitles them at least to that mild adjective, "quaint."

"Nereides or Sea-Eclogues," ${ }_{55}$ by John Draper (always misprinted "Diaper") are the first English poems, written after Drayton's nymphal, that employ Sannazarian imagery, though strictly speaking, only one of them is a fisher eclogue. In his Journal to Stella, Swift particularly mentions this as the earliest book of its kind in our literature, and says that Lord Bolingbroke sent the author the then important sum of twenty pounds. He might have said that it is the only book of its kind in any literature, without being guilty of a gross misstatement. In his dedication to Congreve the poet states that ancient and modern bards have exhausted the beauties of the land:

"But the vast unseen Mansions of the Deep, Where secret Groves with liquid amber weep, Where blushing Sprigs of knotty coral spread And guild the Azure with a brighter red, Were still untouch'd. . .."

His Muse ..." But would plain songs in artless verse contrive, And humbly modest only asks to Dive."

$\mathrm{He}$ declares that the beauties of the sea have been painted only "in a few piscatory eclogues," and that though Lucian wrote of sea-gods it was " chiefly to expose the heathen deities," but "The

${ }^{a s}$ London, 1712. 
best modern productions are owing to hints of Lucian the wit." $\mathrm{He}$ adds that he was encouraged to write of the ocean by accounts of "SeaAnimals in human shape," told of by Aelian and Pliny among the ancients, and by Olaus Magnus, Rंhannusius, Alvarez and other moderns. $\mathrm{He}$ believes that these stories gave rise to tales of nereids, tritons, sirens, with the numerous court of Neptune and Tethys, so that he will not venture to decide whether such beings "have not sometimes (at least as to their outward parts) been found with bodies proportionable, and similar to ours, or like Horace's :

With lovely Face, and flowing Hair

The Nereid looks divinely fair;

But ah! no farther seek to know,

A fishy tail is all below.

His belief in such creatures is strengthened by the modern cases of the mermaid kept at Harlem, of the mermaid, entirely human, told of in the English chronicles, and by the statement of $\mathrm{Du}$ Bartas that the sea holds "The mitred Bishop and the Cowled Fryar." Lastly, he gives credit to the words of Alexander ab Alexandro who says that Theodorus Gaza, ${ }^{56}$ a learned Greek of Pelopponesus, once saw a nereid with shoals of fish stranded by a storm. People gathered to stare at the marvel, but as the mermaid wept bit-

${ }^{60}$ Besides the tales of Gaza Draper may have read other accounts, such as "A most strange and true report of a monsterous fish, who appeared in the forme of a woman, from her waste upwards. Imprinted at London for W. B." This nereid was found in the parish of Pendine, Carmarthen, Feb. I7, 1630 . 
terly, Gaza put her back into the water. Alexander also reports that another Greek saw a nereid sporting in the waves, but when she perceived herself observed she sank from sight. Relying on such authorities, Draper states that while some poets are talking about the inhabitants of other planets, he will turn to the ocean and "discover the manners of people nearer home."

Accordingly his Muse is allowed to "dive" to a new Arcadia in the coral groves of the deep sea. In his eclogues the characters are tritons and mermaids, who wail laments, indulge in singing contests, or perform incantations, in a manner as much like that of the classic pastorals as a careful use of Pope's couplet permits, and yet obvious imitations of Sannazarian illustration ${ }^{57}$ are very numerous. Thus we find the curious case of a poet of the Augustan school, interested in sea-beings, and encouraged by classic and modern lore, composing idylls of mermen and nereids who behave exactly like the personages in Virgil or Sannazaro.

A passage from a pharmaceutria performed by the mermaid Meroe, with her friend Otys, illustrates Draper's manner of fitting classical pastoral activities to their surroundings in the sea:

“Otys, begin ...

Since he is gone, I'll fetch him to my Arms

By sacred spells, and Force of Magick Charms.

Search in the Slime, you'll find the cramp-fish there,

${ }^{57}$ It will be recalled that in Sannazaro's "Proteus" the songs of the shepherd of the sea were made a piscatory. 
That chilling stops whatever swims too near:

You'll find the Fish, that stays the labouring Ship, Tho' ruffling Winds drive o'er the noisy Deep: So Phorbas, while from me he perjur'd flies, Is struck benumb'd, and fix'd with strange surprise."

The fish mentioned are the same, and have the same rather alarming attributes, as those that figure in the Sannazarian piece from which Draper adapted this idyll. Two bits show the influence of Theocritus, the first a new rendering of the old refrain to the moon:

"Look down, auspicious Moon; too well you know What Love will force, and potent Charms can do ..."

and the other the treatment of a poor dog-fish (here substituted for the Theocritean waxen image) which is pierced to torture Phorbas by proxy.

With this incantation may be classed two love complaints, in one of which (ec. 2) Gaza's story is utilized. The mermaid Eune swims ashore with her triton lover, where she falls asleep, and on waking finds herself left high and dry by the tide, Melvin having treacherously stolen away. She weeps, and utters a piteous lament, but in time the sea rolls back over the sands and with the first wave comes her recreant sweetheart. The other plaint (ec. I3) is uttered by Cymothoe, who upbraids our old friend Glaucus for ingratitude-she taught him swimming, with all the other secrets of the deep, when he first tasted 
the magic grass and was "added to the gods," and now he neglects her for the "flat-nosed Cyano." Her reproaches are phrased in the classic manner, only that at the conclusion she makes no threat of leaping from a cliff, but declares that she will swim straight into the nets of fishermen unless Glaucus promises reform at once, and this he proceeds to do. A companion piece is an elegy, obviously a merman rendering of Sannazaro's "Phyllis," and notable for the compliment which the singer receives from his admiring friend:

"Not half so sweet, when first the Morning dawns, Are juicy Oysters, or the lucious Prawns."

The religious allegory of Spenser was not looked on with favor in Draper's day, but one group of the Nereides, related to the eclogues contrasting shepherd life with that at court, reminds us of the old motive in the complacent view which tritons take of their own state, with their scorn for the baser ways of men. In one poem Muraena from the summit of a rock views with contemptuous pity toiling shepherds with their bleating flocks, and tells how, much happier than human beings live the merry mermen. Another presents two tritons moralizing on the false pride of mortals, and declaring the futility of searching to understand the mysteries which Heaven denies to our weaker sight before we become spirits. In tone this is the most serious of the set, but it imitates the amoeboean songs in Sannazaro's third poem, in which ridiculous lists 
of fish are substituted for the classic flower lists. Draper utilizes these catalogues to illustrate the greatness of the Creator, as proved by the marvels of ocean. The most original of this group gives a conversation in which Phorbas and Drymon talk about a terrific naval battle which has taken place, about a fleet in the distance, and about the greed and avarice of men, as reported by the transformed Glaucus. Melanthus comes reeling along the beach, having broached a cask which he has discovered amid some wreckage. He declares that he feels like a king and adds:

“My head's so wondrous light, I scarcely find Whether I move on Waves or dance on Wind ...

I quaffed full bowls in a capacious Shell.

Ye Gods! if earthy Men thus live and drink, Give me the Land, the Sea's a worthless Sink."

The other tritons immediately start in search of the wonderful drink.

Draper composed several song contests, and incidentally made use of Gaza's diving mermaid, coquetting in the waves, who is the prize in one of them (ec. 13). Another exemplifies the conventional exchange of rude banter, and still another is rendered by two nereids, of the wanton type, an interesting touch being the refrain:

"Since nothing here we fixed or constant find, Why should the Nereid boast a settled mind?"

Everywhere in these poems occur bits of pretty description, much better than one might expect 
in a work of such a peculiar sort. Of a seanymph one triton sings:

"Her rising Breasts are white as polished Shells, And in each part a different beauty dwells."

Another typical passage is a challenge:

"Begin, if thou art skill'd in tuneful lay, Now whispering Breezes gentle Sounds convey, The noisy Winds in bolted caves are prest, And now the Halcyon builds her wavering nest."

Virgil's "seizing of Proteus" motive is rendered when Ino and Cete, a merman and a nereid, find that sea-god sleeping near his scaly herd, just as occurs in the fourth georgic. Of course they grasp the old fellow and insist on his singing a song, to which he is forced to assent. He chants an account of the history of the universe modernized (from that given by Virgil's Silenus, when caught by the shepherds in the sixth bucolic) to embody the theories of Draper's day.

Only one of the collection is a true piscatory. In it Murex asks Glaucus if he has seen the fleet, and learns that it has sailed everywhere under command of the great Lacon (Leake). Near England the scaly god overheard the talk of two half-frozen fishermen, who admired the admiral, and repetition of their conversation makes up the idyll proper. The two men are in a skiff toiling at their nets by night, with fingers cramped by the bitter cold. It is new moon and the snowcovered shores are faintly visible through the gray light. Exasperated by his wretched condi- 
tion the younger man decries the fate which drives him abroad on the black sea at a time when even the poorest clown lies at his ease. He draws a picture of shepherd life, which he declares far happier than that of fisher-folk. The old man replies: "All think their Fortune is of all the worst," and says that fishers are in fact envied by countrymen. They eat the choicest of food : cod, mullets, soles and mackerel, fish which landsmen pay large prices for, even when stale. Labor on the waves, too, is easier than that "in clotting fields," for sometimes the zephyrs breathe sweetly, while sands are soft and warm. Nor is their livelihood dependent wholly on fish, since they can scale high ledges, while sea-birds wheel and scream, and can gather plenty of the most delicious eggs. He then praises Lacon, admiral of the English fleet, who protects the isle with its fishers from the attacks of hostile ships. Glaucus pities the men and drives shoals of fish into their seine. There is a certain grim realism about the dialogue and many bits of local color, which distinguish it sharply from the piscatories of Fletcher, Leech and Drayton. Draper's poems, too, are almost unspoiled by the ridiculous pathetic fallacies that characterize so many verses of the genre. In its underlying purpose the eclogue bears some resemblance to Sannazaro's panegyric of Ferdinand, but it is not, like the other Nereides, filled with borrowings of individual Sannazarian conceits, but gives the exotic species a local habitation and a home. Perhaps the two fishers are made real as an example of the Theocritean pis- 
catory transferred to English shores, as is true of one of the pieces by Leech already mentioned. The verse of all these poems, though a bit stiff, is yet replete with happy turns of speech and pieces of description which denote an appreciation of nature unusual two decades before the publication of Thomson's Seasons.

The favorable reception that the Nereides met apparently did not please the contemporary critics, who formulated cut and dried rules for the pastoral. Not long after the poems appeared the Guardian (No. 28, Monday, April I3, I7 I3) printed a severe criticism of Sannazaro's piscatories, of which a few lines are as follows:

"While I am speaking of the Italians, it would be unpardonable to pass by Sannazaro. He hath changed the scene in this kind of poetry from woods and lawns, to the barren beach and boundless ocean, introduces sea-calves in the room of kids and lambs, sea-mews for the lark and the linnet, and presents his mistress with oysters instead of fruits and flowers. How good soever his style and thought may be yet who can pardon him for his arbitrary change of the sweet manners and pleasing objects of the country, for what in their own nature are uncomfortable and dreadful? I think he hath few or no followers, or, if any, such as knew little of his beauties, and only copied his faults, and so are lost and forgotten." This criticism is said to have been written by Addison. It will be noticed that Sannazaro's style (being Virgilian) meets with no censure, but that the critic objects to the arbi- 
trary shifting of the scene from sunny Arcadia to "uncomfortable and dreadful" shores. Perhaps his travels in Italy failed to impress Addison with the quiet beauties of the Bay of Naples, and at any rate, the criticism sounds in every way like the view of pastoralism which was to be expected from the Londoner of the day.

The Guardian probably helped to discourage further imitation of Sannazarian pieces in England, but it is clear that everybody did not agree with Addison. In I724 Beaupré Bell translated Sannazaro's "Salices," and two years later metrical versions of the piscatories appeared, one by Tate, and the other by J. Rooke. In a preface to his translation, Rooke refutes Addison's statements, and defends the pastoral of the sea-shore. $\mathrm{He}$ has no patience with the view, sometimes urged, that the life of fishers does not offer so great a variety of materials to the poet as does the life of shepherds, saying that the experiences of fishermen may not be "so various" but are "sufficient." Lastly he shows that Virgil, whom the critics of the day regard as the highest authority in poetical matters, is especially fond of marine pictures, and that these form definite precedent for the works of Sannazaro and his imitators. The criticism in the Guardian, of course, shows that Sannazaro's followers were not known at this time in England, but the essay of Rooke and the translations indicate that the great humanist had loyal defenders even in this period, more than two hundred years after the composition of his poems. 
Rooke's translations include besides Sannazaro's eclogues, a few by other humanists, such as the very poem by Grotius which suggested to Leech the idea of writing " nauticae." The verse, rhymed couplet, bears a striking resemblance to that of Draper, and in fact may more justly be regarded as rhymed paraphrase than as literal translation. A passage from Buchanan's bucolic "Amaryllis" will illustrate the style:

"So, have I seen a Fisherman convey

His nets ashore, in quest of nobler Prey, And cast a little Tench, with Scorn, away: Who, home at last returned, by Fortune crost, And not a Mullet nor a Tench could boast."

Only a year after the publication of Rooke's poems the Rev. Moses Browne, then twenty-two years old (in the summer of 1727 ), composed the most popular of all English fisher idylls, first published in 1729 , under the title "Angling Sports in nine Piscatory Eclogues-A New Attempt to introduce a more pleasing Variety and Mixture of Subjects and Characters into Pastoral on the Plan of its primitive Rules and Manners, and the lovers of Nature in rural Scenes. With an Essay in Defence of this Undertaking." In the blank verse dedication he writes begging the favor of Dodington as follows :

"Nor, of the rural theme contemptuous scorn An humble Verse, tho' of the watery race, And Fisher's sports descriptive, labour new. The fam'd Sicilian Swain his oaten reed To Ptolemy attun'd, and Maro's Song Made lowly shades deserve a Consul's care 
So might but thine the piscatory strain Engage ...

Nor less delightful shou'd th' unlofty lay

Be then esteemed, that sings of Fishy Lakes

Bank'd with green shade; peace-visited retreats, The Anglers Haunts, and lonely-loving Bard's.

Enrapt I languish for the wish'd retreat, Deny'd to my unhappy choice-For me Hard-lotted hours with chearless round renew, Except, when by the Poet's page enlarg'd, I wander far thro' classic shades renown'd; O'er Helicon, thy hallow'd walk, and thine Green Ida, seat of desolated Troy."

Here we find an angler, kept from his craft by circumstances, and turning to literature, especially to the pastorals of Theocritus and Virgil, for comfort. Like Sannazaro and Grotius he terms his work " labour new," rather a misnomer, considering his obvious indebtedness to Sannazaro and his acquaintance with the eclogues of Fletcher, which as we shall see, gave him several hints.

The introductory essay is an attempt to show that fishermen's activities are legitimate material for pastoral poetry. He takes exception to the view of critics who make Theocritus, Virgil, and Tasso the only writers of real pastorals, declaring that to these names should be added Spenser, John Fletcher, William Browne, Philip Congreve, "with many others." He declares that the true spirit of pastoral is greatly misunderstood, and that clownish or low phrases, obsolete expressions, labored turns of wit, and amorous ex- 
travagances do not make good bucolics. He then shows that in the works of acknowledged masters of shepherd song, Theocritus, Virgil, Tasso, and Spenser, there are frequent divergences from the manner of strict bucolics, such, for instance, as the heroic pieces among the Sicilian idylls, and he recalls the saying of Sannazaro that the pastoral is really a species of epic. He calls the slow perfection of pastoral verse a proof of its greatness, and accounts for the inferiority of the poems by Moschus and Bion with the long gap in the tradition between Theocritus and Virgil by the suggestion that pastoralism had to wait till the "slow advance of genius should raise up some equal to the undertaking." $\mathrm{He}$ adds that Servius allows only seven of Virgil's bucolics to be pure pastorals, and Heinsius rejects for the same reason all but ten of the idylls. He declares this view absurd, showing that husbandmen, vine-dressers, fishers and others are proper subjects for pastoral treatment, not only by nature but by the example of Theocritus and Virgil themselves. He asks why the Reapers, the Two Fishers or others not shepherds should be excluded, continuing thus:

"Why not Anglers, Fowlers and other rural employments, whose leisure, solitude, and innocent manners make them strictly conformable to ... rule. The heavy, precise Grammarians . . . would be hard put to it by their rules to prove the purity of those ten idylliums which they have set apart as regular, or acquit themselves for those they have rejected ... What title has his 
Second, the Inchantment, to the genuine classthe man a town wrestler." He cavils also at the second idyll, and at the seventh, eleventh, and twentieth. After enlarging further on the mingling of characters in the works of Theocritus and Virgil he concludes:

"Both from Theocritus' and Virgil's authority and practice, let but the manners of the speakers be adapted to the simplicity and purity of the golden age; let them have but leisure for their muses, and the country for their residence, and whether they are Shepherds, Anglers, Fowlers ... it is equally indifferent; Nature is a wide field, and varied for contemplation, and the multiform pleasing objects and observations that present themselves from floods, hills, woods, vallies, and plains, and their numerous orders of inhabitants, may furnish the pastoral poet with a choice of familiar beautiful ideas." He concludes this part of the essay by citing the names of many famous writers who have been good anglers and have at the same time written of their art in a way to establish precedent. Among the English writers cited are Dean Donne, Sir Francis Bacon, Sir Henry Wotton and Izaak Walton himself, whose love of angling he extols at some length. What he here says about the "Compleat Angler" is a naive confession of the inspiration that led him to try his hand at writing piscatory poems:

"I found by the Dialogues of his Anglers, how properly they would suit with the innocent, humble nature of Eclogue . . ." a discovery 
which, as has been shown, John Whitney had made some years earlier.

The second part of the essay is not so logical as the first, and the author is guilty of the same fallacy of which he accuses other critics. He thinks that the fishers most suitable for pastoral treatment are gentlemen amateurs, strolling along English streams. Great men have been shepherds, so that a poet is " not deviating from their characters to make them civil and ingenius, and for fear of drawing them courtiers, paint them as savages: the golden mean is to be observed. If . . I have made my Swains . . a little too well bred for natives of the country, it was because I judged my subject not straightened, nor the speakers limited to all the slavish forms the pastoral critics have required." At this point he forgets that the two old fishermen in the idyll by Theocritus, whom he has cited as precedent for the painting of analogous characters in English poetry, are scarcely gentlemen amateurs, and he declares that anglers are legitimate subjects but "Fishers . . . following their laborious employments on the main, are not to be properly reduced to this taste, nor are these the most eligible subjects. If they can be lawfully used, it must be but sparingly, and with some art and management, or they will appear with no advantage. I have used them but once in these eclogues... my professed view in this undertaking was to see how a mixture of characters, and a designed variety of subjects would appear . . I have but one eclogue with Fowlers." $\mathrm{He}$ declares also 
that it would be better if Sannazaro had never written his "sea-eclogues"-_ the exercise of fishing appears so contemptible in him, that any that writes on a subject that seems to be of a similar aspect, must suffer disadvantage. His oysters and crayfish are served plentifully over without any change, and you may break your teeth before you get at his entertainment. His water-swains differ no ways from our most simple ones on land, only that he turns them to sea in an old tattered boat, and so leaves them to wail their loves and seek their fortunes." This criticism of Sannazaro is much more severe than that already cited from the Guardian, but it is clear that Browne calls the exercise of fishing in the humanistic poems "contemptible" chiefly because his own ideal is that of Walton. He evidently examined the thin piscatory disguise in the allegorical poems of Sannazaro, found little technical information about actual fishing, and decided to produce a work which should preserve the classical conventions and types of song as far as possible, and at the same time adapt the piscatory form to the purpose of rendering the "Compleat Angler" in verse. One entire eclogue, to be sure, is imitated from Milton, and despite his savage strictures, one from Sannazaro, but most are based on angling scenes in Walton, with some touches from Bacon, Donne, and others. This Browne tells the reader in copious footnotes, aimed to show that everything in his poems, especially the actual angling lore, is sanctioned by high authority. Here and there 
the influence of Spenser and that of Fletcher are very obvious, and the prose arguments prefixed to the poems, quaintly worded and somewhat specific, are evidently imitated from those in the "Shepherds Calender."

It should be added that Browne's attitude towards the use of a variety of characters in pastoral verse was not typical of the critics of the earlier part of the century, Pope in particular, finding fault with Theocritus because of the very fact that he introduces fishers and harvesters. In spite of his theory, too, Browne after all, wishes only to establish the amateur angler on a par with other characters in pastoral. Fortunately his study of Walton and his experience as an angler led him to abandon the pathetic fallacy, which in earlier pieces made fishes pop their heads out of the water to hear the songs of fishermen. That sort of thing does not appear in the eighteenth century piscatory eclogues, the poets being convinced that it was not consistent with any realistic picture of anglers engaged at their sport.

Having attempted to show that the best precedent exists for the presentation of a judicious variety of characters in pastoral poetry, he closes the essay by ridiculing the idea that shepherds must be in love, citing Dryden's criticism of English eclogues for this affectation - "This Phyllissing comes from Italy." Finally he gives a general eulogy of angling and cites a number of famous fishermen, among them Phineas Fletcher, from whose poems he quotes, Dr. 
Nowell, Dean of St. Paul's, Cicero, Antony and Cleopatra, with others ancient or modern, as they happened to occur to him. It is hardly necessary to remark that Browne fails to show that gentlemen anglers are the most eligible characters for pastoral treatment, but nevertheless his essay and Rooke's are far more logical and show far keener insight into the real nature of country song than does the critic in the Guardian, and than the great Johnson does a little later in the Rambler, as will be shown.

Browne's poems are an interesting attempt, at least, to carry into effect the theories expressed in his preface. Three pieces are contests, one of them beginning in rude banter borrowed and adapted from Virgil's third bucolic. Two youthful anglers sing before the herdsman Mico, who watches them fishing, alternate songs giving an accurate account of the inconveniences to fishermen resulting from long draughts and land floods, the signs and changes of the weather, seasons best for their recreation, and the methods of summer and winter angling. All this knowledge is of course, Waltonian, yet it has the sanction of Augustan criticism in Pope's dictum that the characters in pastoral should be made to know enough astronomy to assist them in the pursuit of their daily routine in life. Browne's singers are rewarded with wreaths of flowers and myrtle, invited to Mico's cottage because rain threatens, and are promised "two rods of smoothest cane with lines of silk and purest hair," if they will teach him to fish and sing as well as they do. 
Another match (ec. 6) between Myrtol and Thelgon, with a third fisher as umpire, is made the vehicle for detailed information about "the nature and breed of fish, their haunts and feeding," with the usual reward, and commendation. The last contest (ec. 7), "The Strife," is imitated in part from Fletcher's "The Strife," and in part from other sources. Just as in Fletcher's poem the match is held before a fisher umpire between an angler and a shepherd, each singing the praises of his own way of life, while the rallying, which leads to the challenge, is that of Virgil's third piece. Browne explains that the shepherd Clorin's song, in compliment to Pan, for the first time embodies in verse the story of Pytis, a nymph beloved by the rural gods, but changed to a pine to escape the rage of Boreas, whom she slighted. Hence Pan crowns himself with pine, and hence the tree sighs when the north wind blows. The fisher Comus relates the metamorphosis of beautiful Sabrina, drowned in Severn, by which the contestants now sit. Browne recalls that the ultimate source of the legend is in Geoffrey of Monmouth, but the use of the names Sabrina and Comus together certainly suggests the influence of Milton's Comus. The refrains, on the other hand, are English variants on those in Virgil (8):

"Ye graces aid, ye muses tune my tongue Thou Pan be present and assist my song"and

"Ye vales, ye rocks, ye caves your echoes bring, And thou, Sabrina, listen while I sing." 
Here we have rather a complicated development of the genre, including motives from Fletcher, Virgil, and Geoffrey of Monmouth. Moreover, the fisher's song describes no fewer than thirty-seven rivers, all taken from Walton, as copious notes explicitly state, and lastly we find imitation of Milton. First suggested, as we have seen, by the names of Comus and Sabrina, this last mentioned influence is made more obvious by a story of how a river-god seized and wed the nymph Sabra. He called the floods to the marriage, and a procession came that is almost certainly imitated from one in Lycidas. A short quotation may serve to make this clear:

"First aged Isca came with flattering pace, And Pedred sprung of Ivel's kingly race; A dropping wreath of Water-Thyme he wore And smiling Munnow came, with youthful Dore."

Let us consider next Browne's use of the lovelay, for although he censures this in his essay, it forms an undertone in the poems which is plainly reminiscent of Spenser. It is first introduced (ec. 2) amid the gloomy surroundings incident to night fishing for trout, and is thus expressed in imagery taken directly from Walton. Laco is the enthusiastic fisherman, and Renock (the poet himself) is suffering from slighted love, as he manages to say gently, between songs on other matters, just as occurs in the fourth idyll by Theocritus. A long footnote on catching trout by night contrasts sharply with the sentimentality of Renock's lament at the cruelty of his mistress. 
A few words from the poem will show one curious effect of combining angling phraseology with the conventional complaint:

" Happy ye eels, who ne'er love's torment know And carp, blest kind, exempt from am'rous woe."

That the introduction of this motive was actually suggested by the Calender is stated by Browne in the argument to another piece, "Renock's Despair," which, curiously enough, is also called "An Imitation of Milton's Lycidas" (ec. 5). "This eclogue," he says, " is of private concern, and contains an amorous soliloquy of a slighted swain, the same who is introduced with a complaint of his unsuccessful passion in the second eclogue (as Spenser more than once introduces his unhappy Colin with a well-known personal meaning). The Poet here, in respect to the ancient birthplace of his family (whose name in the female line he has made his lover personate), has singled out upon this occasion a particular place of action."

The conception of this pastoral, Spenser's Colin metamorphosed into an angler, singing a complaint to "Lovely Stella coy," busied (as the notes assert) in the most scientific and Waltonian style of fishing, and at the same time endeavoring to rival the poetical effects of a poem like Lycidas, is certainly a bold one. Browne is able to turn out couplets with a reasonable degree of fluency, but in attempting to parallel the haunting music of Lycidas in piscatory phraseology, expressive of wrongs like Colin's, his efforts be- 
come almost absurd. On the banks of the Soar he wails of "My luckless fate which never shall amend." Stella is :

"Than Wolf or Pike more fell

With lives of foes their brutal rage they tame, But thou, than savage kind more cruel grown, Prey'st on a heart which love had made thy own."

Adapted from "the slighted shepherd's trade" of Milton, is a statement that it is not "rude" to make "shapely rods of caney reeds," or "weave in silken folds the mimic fly." Such imitation sounds strangely beside more notes on various fish from Walton, Pliny and Martial. The conclusion is quite in the manner of Sannazaro:

"Ye fisher-swains and river maids adieu, And all ye finny droves, a long farewell. . . ."

Renock is going to leap from a lofty cliff, or hang himself, and his ghost will wail in lonely groves.

The love theme appears in one other of the poems (ec.9),"The Complaints, or The Friends." "This eclogue," says Browne, "is a kind of familiar conference between the poet and his friend. The style is designedly more negligent and unlabored than the rest, filled up with little, unconnected pieces of private history (in a manner Virgil conducts a pastoral of the like nature) wherein honourable and grateful mention is made of some names, distinguished by their friendships. The whole has an appearance suited to the condition of mind (produced by a series of disappointments and dejections) under which it 
was written." The Virgilian model is the first bucolic, in which Tityrus (Virgil himself) talks with a friend about his gratitude to Maecenas, who has restored to him his farm, from which he had been ousted. In the English imitation Renock (the poet) laying down his catch of fish, rests in the shade with Milo, who has been gathering fruit. Renock sings his sorrow at the death of a patron, Molesworth ("author of Cato's letters"), and Milo answers with best wishes for Renock's happiness, giving a Waltonian turn to the conventional pharseology in these words: "nor greedy poacher e'er thy Fry destroy." This first division of the poem, then, is a frank imitation of Virgil. After a time, however, Renock is led to speak mournfully about "Proud Stella! Angel with a tyrant's heart!" Though she has been "torn from my arms-vainly doating I will still love," and this leads to Milo's begging him to "repeat the song that won a prize from Moeris." Renock accordingly utters a sad plaint, descriptive of winter and its ill effects on fish, but Colin's dismal strain (in the wintry December eclogue of Spenser's Calender) makes itself heard in spite of unusually copious annotation from the "Compleat Angler." Sannazaro's lament (ec. 5) furnishes Browne with a suitable refrain:

"From seas haste, Proteus, with thy wat'ry wain And thaw the floods, and save thy dying train."

One of the frankest adaptations of matter from Walton is "Linus and Aquadune." The fisher Aquadune calls on the swain Linus to help 
him recover a trout with which an otter is trying to make off. The episode is taken from one in the "Angler," but Aquadune's moralizing account of the calamities of fish, the poet states that he based mainly on Donne's twenty-ninth sonnet, which is as follows:

"Is any kind subject to rape like fish?

Ill unto man they neither do nor wish.

Fishers they kill not, nor with noise awakeThey do not hurt, nor strive to make a prey Of beasts, nor their young Sons to bear away. Fowls they pursue not, nor do undertake To spoil the nests industrious birds do make. Yet them all these unkind kinds feed upon, To kill them is an occupation

And Laws make Lents and Fasts for their destruction."

A single piece introduce fowlers. In the argument Browne says :

"This eclogue, it will be easily observed, consists of different characters from the rest, and was designedly introduced, consistent with the plan, as a trial how a subject of this new and unattempted nature might be intermixed with a pastoral kind." The poem is another "pharmaceutria," with a love lament, given as in Sannazaro, charm first and complaint second, a reversal of the order of these parts that the humanist was the first to try. A shepherdess, Melite, strives to win back a fowler by incantations and charms, in which all the terms and ingredients for sacrifice are borrowed from "fowling" phraseology. The refrain is imitated from the one in Theocritus: 
"Inconstant moon, fair wand'rer, change his mind Or make me scorn, or make my tyrant kind."

Thrysil's complaint to Phylla is as close an imitation of the conventional form as is the charm, and contains the refrain:

"My voice, my reed, shall in their turns complain; Here mix, my moving pipe, thy sweetly mournful strain."

Even the fowling lore, as the notes make clear, is taken from bits in the "Angler."

In addition to the Sannazarian touches already noted in the poems, mention should be made of the fourth eclogue, the only one portraying professional fishermen of the deep sea, and it is manifestly imitated from Sannazaro's third piscatory. As the poet summarizes the content of the piece:

"A company of fishers, forced by bad weather, take harbour up a shady creek where they divert and refresh themselves. An aged swain (at their request) entertains them with a song in praise of their humble, happy profession, in which by a designed variety, he passes to the different wonderful properties of some rivers, and of several curious remarkable sea-fish, and by occasion suitable to his subject introduces the Episodes of Arion and of Glaucus-but is interrupted by the return of a calm, which invites them back to their employments."

The entire poem is much like the Sannazarian source, only that the contest in that piece is replaced by the solo of the old fisher. The fish lists of Sannazaro are enthusiastically expanded, 
however, in a manner more like that of Walton and of Walton's sources, all of which is acknowledged by Browne in the footnotes. Thus he cites Walton's account of the "hot sargus," and of the "chaste mullet"- - taken from Du Bartas, and from Aelian's "Treatise of living creatures." The stories of Glaucus and of Arion, which the old fisher sings, Browne renders from the account in Ovid, and the final account of extraordinary rivers from Boyle's "History of Firmness and Fluidity," from Virgil, and from Gordon's Geography, from Aristotle, and from "A Jesuit's Voyage to Siam." All this frank admission of indebtedness is very unusual and convenient, but it, too, is only a characteristic suggested by the example of the "Angler," in which the author is careful to indicate the sources of his information, whenever it is not obtained by actual observation alone.

Browne's eclogues have thus a quasi-scientific tone which is rather out of keeping with the classical forms of pastoral verse, but in them appear shepherds, herdsmen, deep sea fishers, fowlers, and anglers, the variety promised in the introductory prose essay. Expert anglers, pursuing their sport along placid streams are his favorite dramatis personae, however, and his contribution to literature may be justly called a blending of the Sannazarian piscatory conventions with the material of a treatise on fishing. There is a strongly marked didactic purpose in this combination of motives, and the poems are in the nature of miniature essays on angling 
adapted to the inherited technique of the pastoral idyll. The couplets in which most of the pieces are written are very correct, and contain many passages of some prettiness and charm, in a purely conventional way. The work was well liked, was reprinted in $1739,1758,1773$ (in one volume with Fletcher's piscatories) and has a place today beside the "Compleat Angler" in libraries of angling literature.

Apparently Dr. Johnson thought Browne might have been better employed, because he urged him to re-edit Walton's book, no edition of which had appeared since 1676 . This task Browne undertook with enthusiasm, loving the work not only as a treatise, but also as a piece of good literature. As he says in his preface:

"Mr. Izaak Walton's Complete Angler ... has been always had in the greatest reputation, by such as are acquainted with books, and have any discerning in works of merit and nature. Not only the lovers of this art, but all others, who have no inclinations in the least to the diversion of angling that it treats of have joined in giving it their mutual suffrage and commendation."

In spite of this encomium, Browne thought it necessary to polish Walton's style, to omit parts here and there, and to smoothe any irregularities that he found in his verse, all with the purpose of adapting the book to suit the artificial standards of the day.

The edition appeared in 1750 , and that same year Johnson published in his "Rambler" "The Reason why Pastorals delight" (no. 36, Satur- 
day, July 21,1750 ), in which he kindly laid down some rules for pastoralism, and showed at some length the reasons why Sannazaro's plan ought not to be followed. The criticism of the fisher idylls begins with a confident explanation of the motive that led Sannazaro to write as he did:

"The conviction of the necessity of some new source of pleasure induced Sannazaro to remove the scene from the fields to the sea."

$\mathrm{He}$ then cites the censure in the Guardian which declares the sea "an object of terror" unsuited to pastoral presentation, and remarks that the poet has a right to select his images, and can as easily describe a calm sea as the bucolic writer can picture a calm day on shore. His objections to Sannazaro's eclogues are that the sea presents much less variety to the poet than does the land, so that descriptive writers must soon exhaust the possibilities of marine imagery. $\mathrm{He}$ says, too, that the greater part of mankind must always live in utter ignorance of maritime pleasures, and for this reason a sea poem will always remain for an inlander as unintelligible as a chart. These things, he believes, Sannazaro did not perceive because he wrote in Latin, and for the learned few-had his piscatories been written in the vulgar tongue, people would not have taken the trouble to read and understand them. It is hardly necessary to add that the Theocritean idyll is not in the least like a chart to the landlubber, and that the Italian piscatories had been popular for a century before Johnson wrote. 
His view, nevertheless, seems to have been generally accepted, and imitation of Sannazaro in England accordingly ceased. Browne's adaptation of a Sannazarian poem, at best but an effort to show how that sort of thing might have been done-a kind of gentle correction, as it were, of Sannazaro's "contemptible" professionalism, is really the last of the strictly classic type to keep the piscatory form.

Eight years after the publication of Johnson's essay in the Rambler appeared William Thomson's "Hymn to May," which the poet states is an imitation of Spenser and of Phineas Fletcher. Part of the introduction is, in fact, a piscatory idyll filled with the new feeling for nature, so little understood by the writers of Pope's generation. The speaker, addressing Ianthe says:

"Let us our steps direct where father Thame In silver windings draws his humid train, And pours, where-e'er he rolls his naval stream, Pomp on the city, plenty o'er the plain: Or by the banks of Isis shall we stray, (Ah, why so long from Isis' banks away!) Where thousand damsels dance, and thousand shepherds play?

Amid the pleasaunce of Arcadian scenes, Love steals his silent arrows on my breast; Nor falls of water, nor enamel'd greens, Can soothe my anguish, or invite to rest. You, dear Ianthe, you alone impart Balm to my wounds, and cordial to my smart: The apple of my eye! the life-blood of my heart!

With line of silk, with hook of barbed steel 
Beneath this oaken umbrage let us lye, And from the water's crystal bosom steal Upon the grassy bank the finny prey: The perch, with purple speckled manifold; And carp, all burnish'd with drops of scaly gold. Or shall the meads invite, with Iris-hues And Nature's pencil gay diversify'd, (For now the Sun hath lick'd away the dews), Fair flushing, and bedeck'd like virgin-bride! Thither, for they invite us, we'll repair, Collect and weave (whate'er is sweet and fair) A posy for thy breast, a garland for thy hair."

The lyric feeling in this piece, like that in Drayton's sixth nymphal, differentiates it to some degree from most Augustan eclogues, in which (so far as structure is concerned) the important thing is the imitation of a set model from the classics.

Almost the last development that took place in the English piscatory eclogue is exemplified in "The Anglers-Eight Dialogues in Verse," published in 1758 by Dr. Thomas Scott, a dissenting minister of Ipswich, and an ardent admirer of Walton, whose Angler he extols in his poems. The purpose of the pieces, like that of Whitney and of Browne, is to emulate the glories of the famous treatise. Browne succeeds in preserving most of the traditional themes for the ecloguethe contest, the complaint, etc., sung by anglers who manage, somehow, to give expression to a great deal of Waltonian lore. Scott rejects all the traditional motives, introduces only anglers as characters, and preserves the amoeboean form only that these characters may tell all they know 
about fishing, in the style most approved by English sportsmen. The kind of arguments in favor of angling which Walton makes incidental to a debate between an angler, a hunter and a falconer, Scott puts into the mouths of Candidus and Serius, who take the matter up with enthusiasm in the first eclogue. Then follow "Some General Rules of the Sport," in a conversation between Tyro and Piscator, his experienced tutor. Next Musaeus talks with Simplicius about "Angling for trout"; Garrulous and Lepidus discuss "Angling for Perch"; Lucius and Verus tell all they can about capturing carp; Iapis and Mysta expound the mysteries of "mixed angling"; Axylus, Musaeus and Chiron converse on "Trowling for Pike," and finally Icenus and Caurus take up the matter of "Fishing for Pike with Layhooks." Like Whitney's dialogue these are didactic treatises in miniature, phrased in couplets and interspersed with occasional lyrics, as in Walton, aimed to illustrate points that arise during the course of conversation. The characters are anglers, far too careful to frighten the fish by singing while they whip the stream, and about as far removed in every way from the swains in Sannazaro as it is possible to be. An examination of the eclogues, however, shows that the author was an educated man, conversant with the traditional forms for the pastoral, and that he frankly preferred to render the "Compleat Angler" in eclogue form rather than to attempt a ridiculous compromise between the outworn 
classic conventions ${ }^{58}$ and the treatise, which Browne had attempted.

Scott's dialogues were reprinted (I773) in "A Collection of Scarce, Curious and Valuable Pieces, both in Verse and Prose, chiefly selected from the fugitive Productions of The Most Eminent Wits of the Present Age," published at Edinburgh by W. Ruddiman in 1773 . The whole set of eclogues was later boldly pirated by Thomas Pike Lathy and embodied in his poem in ten cantos called "The Angler," which was published in 1819,1820 and 1822 .

So the fisher eclogue was found wanting even for quasi-sporting verse, and gradually disappeared. It never attained in England the vogue which it had enjoyed in Italy, partly because the classic types of song were not found flexible enough to adapt themselves to the needs of the only branch of angling literature which was destined to much popularity, and partly because the angler poetry in Walton's treatise, which was allowed to set the style for such matters, was almost exclusively lyric. The few ramifications of the genre in England, though not important by themselves, form, when grouped with analogous developments on the continent, a considerable body of poetry, small if compared with pastoral of the woods and fields, but fairly continuous, and illustrating so long as it lasts, the per-

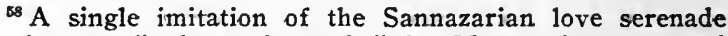
motive, an "ecloga piscatoria" by Metastasio, composed to be set to music, was printed in the appendix to Sir John Hawkin's 1784 edition of Walton's Angler. The piece is not found in Metastasio's works. 
sistence of characteristics derived from the verse of Theocritus, Virgil and Sannazaro. The conventions of country song had become the thinnest of shams long before they entered English literature, yet almost to the end of its existence the fisher pastoral included occasional glimpses at the realistic side of life inspired by the tradition that began with the idyll of the two old men, and the dream of the golden fish.

When the exotic pastoral died out in England it left in its place a branch of literature destined to attain great bulk, if little else. This was the angling georgic, the joint result of the hearty British love for the gentle sport, and of admiration for Virgil. The germs of such works were undoubtedly in such compositions as the didactic dialogues by Whitney and Browne, but it remained for John Gay to demonstrate in his "Rural Sports" the feasibility of employing the mechanism of Virgil's Georgics to combine description of piscatory and other country sport, with idyllic pictures of rural life.

Some of his lines addressed to Pope declare that:

"Where fields and shades, and the refreshing clime, Inspire the sylvan song, and prompt my rhyme, My muse shall rove, through flowery meads and plains,

And deck with Rural Sports her native strains; And the same road ambitiously pursue, Frequented by the Mantuan swain and you."

so " Rural Sports," a Georgic inscribed to Mr. Pope, 1713. Quotations are from canto one. 
By a "murmuring brook" he will read “the Mantuan's Georgic strains, And learn the labours of Italian swains."

If we place side by side Gay's pictures of rural scenes in England with Dryden's translation of Virgil's Georgics, we see at a glance how very skillfully the poet managed to imitate at once the manner of the great Roman and that of his friend Pope. Space forbids quotation from any of the numerous descriptions save that of angling, to which more than half of the first canto is exclusively devoted. The illustrations are drawn from actual observation, but are agreeably free from the heavy, didactic note distinguishing the poetry of Browne. Spring, of course, is the season for the sport:

"When genial Spring a living warmth bestows, And o'er the year her verdant mantle throws, No swelling inundation hides the grounds, But crystal currents glide within their bounds; The finny brood their wonted haunts forsake, Float in the sun, and skim along the lake; With frequent leap they range the shallow streams,

Their silver coats reflect the dazzling beams."

At this season the angler prepares for the field:

"Now let the fisherman his toils prepare, And arm himself with every watery snare; His hooks, his lines peruse with careful eye, Increase his tackle, and his rod retie."

All being prepared he betakes himself to a brook, and: 
"Far up the stream the twisted hair he throws, Which down the murmuring current gently flows; When, if or chance or hunger's powerful sway Directs the roving trout this fatal way, He greedily sucks in the twining bait, And tugs and nibbles the fallacious meat!"

A struggle royal ensues:

"How thy rod bends; behold, the prize is thine! Cast on the bank, he dies with gasping pains, And trickling blood his silver mail distains."

After this picture Gay gives exact and Waltonesque instructions about the preparation of the various sorts of live bait and the circumstances under which they should be used. Turning then to angling in shallow rivers in sunny weather, he enumerates the steps to be followed in the preparation of artificial flies:

"To frame the little animal, provide All the gay hues that wait on female pride. Let nature guide thee: sometimes golden wire The shining bellies of the fly require;

The peacock's plumes thy tackle must not fail, Nor the dear purchase of the sable's tail. Each gaudy bird some slender tribute brings, And lends the growing insect proper wings."

He gives elaborate directions of this sort, with more about the choice of flies for the season of the year and to suit the feeding habits of fish in particular streams, and then after giving directions for trout fishing, describes the playing of an enormous salmon. The canto closes with warning to kill the otters that infest the streams, 
and with strictures on unsportsmanlike devices, such as "the thievish nightly net," the "barbed spear," and with eulogy of fly fishing, as the finest of sports.

At the beginning of the second canto Gay remarks :

"Now, sporting Muse, draw in the flowing reins, Leave the clear streams awhile for sunny plains, Should you the various arms and toils rehearse, And all the fishermen adorn thy verse; Should you the wide encircling net display, And in its spacious arch inclose the sea; Then haul the plunging load upon the land, And with the soal and turbot hide the sand, It would extend the growing theme too long, And tire the reader with the watery song."

This passage gives about the same space to sea fishing as is found devoted to it by Virgil (georgic 4), but Gay was interested primarily in amateur fishing, so the professional pursuit of the craft is left alone, and he goes on to describe the various pleasures of hunting, with many charming sketches of out door life with dog and gun, or with horse and hounds.

It will readily be observed that the first canto of this poem is in some ways merely an elaborate fisher idyll fitted to the English taste for angling, and in various adaptations of that form the genre spread and multiplied for more than a century. ${ }^{60}$

James Thomson told Collins that he took the first hint for "The Seasons" from the four titles of Pope's pastorals, and it is quite possible, too,

${ }^{80}$ See "Biblioteca Piscatoria." 
that Gay's angling scene may have suggested a very similar passage in the familiar "Spring" (I728). Whether this be so or not Thomson's poem embodies one of the liveliest pictures of the sort in English literature. First the poet gives the proper time for the sport:

"Now, when the first foul torrent of the brooks, Swelled with the vernal rains, is ebbed awayAnd, whitening, down their mossy-tinctured stream

Descends the billowy foam-now is the time, While yet the dark-brown water aids the guile, To tempt the trout."

Like Gay he scorns the worm, advising:

"The well-dissembled fly,

The rod fine-tapering with elastic spring,

Snatched from the hoary steed the floating line, And all thy slender watery stores, prepare."

$\mathrm{He}$ describes the best weather and the likeliest spot for a rise:

"Just in the dubious point, where with the pool Is mixed the trembling stream, or where it boils Around the stone, or from the hollowed bank Reverted plays in undulating flow, There throw, nice-judging, the delusive fly; And, as you lead it round in artful curve, With eye attentive mark the springing game. Straight as above the surface of the flood They wanton rise, or urged by hunger leap, Then fix, with gentle twitch, the barbéd hook; Some lightly tossing to the grassy bank, And to the shelving shore slow-dragging some, With various hand proportioned to their force. 
Like a good sportsman he urges the angler to throw back into the stream the smaller fish caught, adding :

"But should you lure

From his dark haunts, beneath the tangled roots Of pendant trees, the monarch of the brook, Behoves you then to ply your finest art.

Long time he, following cautious, scans the fly; And oft attempts to seize it, but as oft The dimpled water speaks his jealous fear."

Lucky is the angler if the giant bites:

"At last, while haply o'er the shaded sun Passes a cloud, he desperate takes the death, With sullen plunge. At once he darts along, Deep-struck, and runs out all the lengthened line; Then seeks the farthest ooze, the sheltering weed, The caverned bank, his old secure abode $;^{\text {6on }}$ And flies aloft and flounces round the pool, Indignant of the guile. With yielding hand, That feels him still, yet to his furious course Gives way, you, now retiring, following now Across the stream, exhaust his idle rage;

Till, floating broad upon his breathless side, And to his fate abandoned, to the shore You gaily drag your unresisting prize."

With the growth of this branch of the species the present book does not pretend to deal, since it is hardly to be classed as pastoral verse, unless under a very elastic definition. In one very different piece, however, we catch once more the

oon In the Latin poem already cited by Vanieri occurs a passage almost identical with this sentence and with the following one. 
spirit of the gray myths of ocean divinities in far off Greece, and of the story of Glaucus, the fisher of the Golden Age, as told by Keats in Endymion.

It is a far cry from Theocritus to the year I8I8, yet the life of Keats' fisher ${ }^{61}$ is not far different from that described in the Sicilian idylls. Glaucus says of himself :

"I touched no lute, I sang not, trod no measures;

I was a lonely youth on desert shores.

My sports were lonely, 'mid continuous roars

And craggy isles and sea-mews' plaintive cry,

Plaining discrepant between sea and sky.

Dolphins were still my playmates; shapes unseen Would let me feel their scales of gold and green,"

His was a silent existence:

"... the crown

Of all my life was utmost quietude;

More did I love to lie in cavern rude,

Keeping in wait whole days for Neptune's voice, And if it came at last, hark, and rejoice!"

Finally he was a near neighbor to the shepherds and a sharer in their idyllic life:

"There blushed no summer eve but I would steer My skiff along green shelving coasts, to hear The shepherd's pipe come clear from aerie steep, Mingled with ceaseless bleatings of his sheep: And never was a day of summer shine, But $I$ beheld its birth upon the brine: For I would watch all night to see unfold Heaven's gates, and Aethon snort his morning gold

${ }^{\circ}$ See Endymion, Book 3, 337 fol. 
Wide o'er the swelling streams: and constantly At brim of day-tide, on some grassy lea, My nets would be spread out, and I at rest. The poor folk of the sea-country I blest With daily boon of fish most delicate: They knew not whence this bounty, and elate Would strew sweet flowers on a sterile beach."

Critics who write of the pastoral often half apologize for the fact that in England the species did not take a realistic turn, save in such occasional poems as those of Gay's "Shepherd's Week." What the poets of the Romantic school thought of the adaptability of the exotic genre to purposes of realism is adequately shown by their neglect of the classic pastoral, a subject far beyond the scope of this book.

It has been shown that piscatory eclogues are only a special field of the classic pastoral introduced from Italy, a mere variant played on the ancient reed pipe. In Theocritus the pictures of fishers are as vivid as those of shepherds, and in the later decadence of bucolic poetry we find the faults of the piscatory akin to those of the more regular form of country song. Naturally, as we have seen, there is no more real fish lore in the poems of Phineas Fletcher than there is of sheep-craft in Spenser's Calender.

Poems on angling, as must have been realized at an early date, should strive at exactness of observation, a thing absolutely foreign to Fletcher's conception of the possibilities of the genre which he attempted to exploit in England. Thus the "Secrets of Angling," first published by 
John Dennys in 1613 , and composed in stanzas almost exactly like those of Fletcher, owes its undoubted success as a piece of literature to the nice and discriminating descriptions and observations with which the author elucidates the gentle art, but it is no more a pastoral than is a treatise on raising sheep. It should be classed with the angling treatises, itself the first one in English verse, but really descended lineally from the same stock as that in Latin and Anglo-Saxon sometimes attributed to Aelfric, and from "A Treatise of Fysshynge with an Angle," written by Juliana Berners in 1496.

John Dennys is the first of a long line of poets who devoted themselves to poetry on angling, and his realistic muse is she whom Moses Browne, as has been shown, attempted to hamper with the fetters of the classic conventions, an attempt which was destined to fail of result.

In Sir Walter Scott's “Antiquary,” (1616), we find elements which open an interesting field for speculation. Here we read prose idylls drawn from the lives of actual Scotch fishers, of the same sort, doubtless, as those whom Ben Jonson had in mind when he planned to write a Scotch piscatory drama. All is pictured from life: the smoky huts, the boats drawn up on the beach and reeking with pitch, the noisy fish-wives, the chatter of girls, the simple lives of simple folk, the old fisher-sibyll with her extraordinary loreitself a match for that of the "wise" shepherd of pastoral tradition, the scraps of fisher song. A poet might have done much with such sub- 
jects-but the day of the eclogue was past, and did not return.

It remains to mention a single work which has no immediate connection with the English fisher poem, but which may in a way be considered the last piscatory of the Sannazarian line, Lamartine's "Graziella, a story of Italian Love." The scenes described in this wonderful idyll recall on every page the shores so loved by Sannazaro, and the life led there by Lamartine among the fishers is as primitive and picturesque as that shown in the poems of Theocritus. "There are no differences," says the author, "between the shepherd or laborer of our mountains and the fisherman of the Gulf of Naples than those of location, language and calling. The furrow or the wave inspires with the same thoughts the man who tills the ground and the man who toils upon the sea. Nature speaks the same language to all those who receive nourishment from her bosom, whether it be on the mountain or on the ocean."61a

Lamartine asks an old fisher to let him share his arduous life, which he commends. The man replies, "You are right," and then, "It is a trade that makes the heart contented and the soul confident in the protection of the saints. The fisherman is under the immediate charge of heaven. Man knows not whence comes the wind or the wave. The file and the plane are in the hand of the workman, riches and favor are in the hand of the king, but the boat is in the hand of God."

Ga Translation by J. B. Runnion, Chicago, 1876 . 
The hut of the fisher is on a lofty rock above the sea-"A great fig tree and some tortuous vine stalks were bending over the angle of the house, confusing their leaves and fruits at the entrance of the walk, festooned and creeping over the wall that supported the arcades above. Their branches half formed bars to the two low windows that looked out upon this little garden walk; and if there had been no window, the low, square and solid house might have been mistaken for one of the light gray rocks, peculiar to the coast, or for one of those blocks of petrified lava (entwined in the branches of the chestnut, the ivy and the vine), out of which the grape cultivators of Castellamare and Sorrento hew caves, close them with a door, and there preserve the wine by the side of the stock that first bore it."

The inside of the cabin was "as bare ... as the outside. . . The walls were entirely without plaster and only covered with a thin coat of whitewash. The lizards, aroused by the light, shone in the crevices of the rocks and crept under the fern leaves that served as the children's bed. Nests of swallows, whose little black heads peeped out, and whose restless eyes twinkled in surprise, hung down from the beams, still covered with bark, which formed the roof."

There Lamartine lived the life of a fisherman, a hard life, but a contented one-changing little from age to age; there he heard the weird old fisher songs, that have been sung since no man can tell when, and there he met the fisher-girl with whom he fell in love. The pathetic verses 
in which he mourned the death of his sweetheart may be considered the last notable elegy among idylls of fishermen, and like so many of the earlier ones the poetry finds its key note in the grayness and sadness of the sea. 


\section{APPENDIX}

The influence of Sannazaro's work, particularly of the Arcadia, on French and Spanish literature has been treated among others by Francesco Torraca, in his Gl'Imitatori Stranieri di Jacopo Sannazaro (Rome, I882). This is an interesting work, but not very accurate, as may be seen from such indications as the fact that the author states that Sir Philip Sidney imitated Sannazaro's Arcadia, and then admits never having read the English work.

A good account of the Italian piscatory is Mario Mangani's Origine e svolgimento dell' egloga pescatoria italiana (Nicastro, Bevilacqua, 1902).

M. Antoine Campaux, in a pamphlet entitled De Ecloga Piscatoria qualem a veteribus adumbratam absolvere sibi proposuit Sannazarius (Paris, 1859), covers much the same ground as the introductory portions of the present work. M. Campaux did not attempt, however, to trace the relationship between the piscatory and the bucolic, but simply to list the early examples of pictures of fishermen which Sannazaro may have known, and to sketch the main lines of his influence in Italy (especially in Neo-Latin) and in France.

The present work aims to treat the idyll of fishers as part of the broader field of pastoral in Europe, of which the English is but a corner. 
Note. The translations in this volume from Theocritus and Moschus are by Mr. A. Lang.

\section{Germany}

The influence of Sannazaro in Germany was apparently slight. The best examples are Hulric de Hutten's Latin hexameter poem De Venetorum Piscatura, 1488, and the vernacular Fischergedichte und Erzählungen by F. Bronner, Zurich, I787.

In German dramatic literature are Theodor Körner's Fischermadchen (Berlin, Dramatische Beytrage), I82I, and Goethe's "Fischerin" which was composed at Weimar, and was intended for presentation on an open air stage.

The fisher scenes in Schiller's Wilhelm Tell are too familiar to call for comment. It will be recalled that the play opens to the accompaniment of the "Kuhreihen," and that there follow three songs: one rendered by a fisher boy in his skiff, one by a herdsman on the mountain side, and one by a hunter on the rocks. Here we find once more placed side by side the figures so familiar in humanistic eclogues. 


\section{BIBLIOGRAPHY OF PISCATORY LITERATURE}

AELFRIC. For the angling treatise attributed to Aelfric see W. W. Skeat, "An Angler's Notebook." London, I880.

Aesop. Fables. Edwin Pearson. London, r87r. Alciphron. Epistles in which are described The Domestic Manners, The Courtesans, and Parasites of Greece. Now first translated from the Greek. London, I79I. Amaltheus, J. (Giovanni Battista). See J. Rooke. Complete poetical works in Amalteo Girolamo Trium fratrum Amaltheorum Carmina. I689.

Antiphanis. Fragments. See Athenaeus. Arabian Nights. Book I. Translation for the

Burton Club. London, I885-88. ARChippus. Fragments. See Athenaeus. ArIon. In The Poets of Greece. Sir Edwin

Arnold. London and New York, I869.

Athenaeus. Deipnosophists; or, Banquet of the learned; literally translated by C. D. Yonge, with an appendix of poetical fragments. London, I854.

Ausonius, Decimus Magnus. Opera Omnia, ex editione Bipontina. Valpy's Delphin and Variorum Latin classics. London, I823. Bagno, Ferrante. Maritime eclogues. Casal Monferrato's Academy of Argonauts' publications circa I 547. See E. Carrara, P. P. 
Baldi, Bernardino. Egloghe Miste. Venice, 1590. The same, "Ordinate e annotate," Firenze, 1859 .

Beaumont and Fletcher. The Maid's Tragedy. The False One. In complete works. Bell, Beaupré. A translation of Sannazaro's Salices. A mss. at Trinity College. Cambridge, 1724 .

Belleau, Remy. La Bergerie. Paris, ${ }^{5} 6_{5}$ (part I). $\quad 1572$ (part 2). Both pub. A. Lemeurre, Paris, 1878 .

Bernardino, S. Sonetti e Canzoni, con L'egloghe pescatorie. Naples, 1560.

Bernardes, Diego. Olyma, I596. See Camoens, Luis de. Deutsch von Wilhelm Storck. Paderborn, 1880. Notes.

Bibliographia Piscatoria. Thomas Westwood and Thomas Satchell. London, $x 883$.

Binet, Claude. Quelque Autres diverses Poesies de Claude Binet. Paris, I573.

Bron. See Theocritus, Bion and Moschus rendered into English Prose. A. Lang. London and New York, I889.

Biondi, Luigr. Egloghe di Virgilio, di Calpurnio del Nemesiano, di Petrarcha e del Sannazaro Volgarizzate dal Marchese Luigi Biondi. Rome, I84I.

Bottazzo, G. I. Eclogues. Casal Monferrato's Academy of Argonauts' publications, I547. See E. Carrara, P. P.

BRIsset, Roland. Translation of Ongaro's A1ceo. Paris, 1596. Another by Claude le Villain. Paris, 1602 . 
Brizeus, A. La Plainte du Pécheur. See Les Ternaires. Paris, I84I.

Browne, Moses. Angling Sports : in nine piscatory eclogues. London, I729.

Browne, William. Inner Temple Masque. London, I6I4. Brittania's Pastorals. London, I6 3-14, bk. I. I6 6 , bk. 2. I852, bk. 3.

Calderon de la Barca. El Golfo de Las Sirenas. Las Comedias, ed. J. J. Keil. Leipsig, 1827-30.

Callimachus, Cyrenaeus. Hymns, an Elegy on the bath of Pallas and Epigrams. Hesiod. Works. Translation by J. Banks. London, I856. See also Athenaeus for fragments.

Calmo, Andrea. Rime Pescatorie, Venice, I $55^{\circ}$.

Reprinted as Le Bizarre, Faconde et Ingeniose Rime Pescatorie. Venice, $1557,76,82$.

Camões, Louis de. Eclogues. Deutsch von Wilhelm Storck. Paderborn, I880.

Campaux, Antoine. De Ecloga Piscatoria qua-

lem a veteribus adumbratam absolvere sibi proposuit Sannazarius. Paris, I859.

Capaccio, Giulio Cesare. Mergellina. Egloghe Pescatorie. Venice, I598.

Cárrara, Enrico. Poesia Pastorale. See Storia dei Generi Letterarii Italiani. Milan, Igog. Cholmeley, R. J. The Idylls of Theocritus, Edited with Introduction and Notes. London, I9OI.

Codax, Martin. Fisher songs. See D. Marcellino Menendez Y Pelayo-Antologia de Poetas Liricos Castellanos Desde la Formacion del Idioma Hasta Nuestras Dias. Madrid, I892. 
Cotta, Giovanni. Ecloga Piscatoria. Verona, Ante 1510. See his Carmina, in Fracastorio, G. Poemata Omnia. I7 I8, pp. I85-206. Daniel, Samuel. Ulysses and the Siren. London, 1605 .

Decimus Laberius. Otto Ribbeck, "Comicorum Romanorum . . . fragmenta." Leipsig, 1898 .

Delille, Jacques. L'homme des champs. See Oeuvres. Paris, I824.

Dennys, John. The Secrets of Angling. London, I6I3.

Diaper, John. Nereides or Sea-Eclogues. London, I7I2.

Du Bellay. Defense et Illustration de la Langue francaise. Paris. A. Lemeurre, 1878 .

Donne, John. Poems. London, $16_{33}$.

Drayton, Michael. The Muses Elyzium. London, I630.

Emerson, O. F. Some of Chaucer's Lines on the Monk. Mod. Phil., vol. I, 1903-4.

EPicharmus. Fragments. Athenaeus. Seealso

K. J. Grysar's De Doriensium comoedia quaestiones. I828.

Erasmus, Desiderius. Venatio. See his Colloquia familiaria. Leipsig, I7I3. (First ed. Paris, 153I.)

Fletcher, John. The Faithful Shepherdess. London, I609-10.

$\int$ Fletcher, Giles the Elder.

Fletcher, Giles the Younger. See Ed. A.

B. Grosart. London, 1876.

Fletcher, Phineas. 
Fletcher, Giles the Elder. See also Three Latin eclogues on page 185 of Poemata Varii Argumenti Partim E Georgio Herberto Latine (Utcunque) reddita, Partim conscripta a Willi. Dillingham. S. T. Cantabrigiensi. Adscitis etiam aliis aliorum Londini. Typis E. Flesher, I678. (C. U. L. $878 \mathrm{D}, 58$.

Fonteny, JACQUeS DE. “Iolas.” See Colletet"Vita poetarum Gallorum."

Ford, Simon. Piscatio; ad Gilb. Arch. Cant. S. Ford. In Musarum Anglicanorum Analecta. Oxford, I692. Translated by Typping Silvestre. Oxford, I733. For other translations see Bibliographia Piscatoria.

Frondius, N. Disputatio de Piscatura Harengorum in Roslagia : respondente Nils Humbli. Upsal, I745.

Gambara, Lorenzo. Piscatory eclogues. Rome, circa 1561 .

Gamon, Christophe DE. Les Pescheries. Lyons, I598.

GAy, John. Rural Sports. A georgic inscribed to Mr. Pope. London, I7I3.

Giannetasius (Nic. Parthenius). Halieutica, a treatise in verse. Naples, I685, 86, 89, 96. Piscatoria et Nautica, Naples, I685, 86, 92. Both poems in ed. Naples, I7IO-14, 22.

Goina (Goynaeus). Ecloga Piscatoria. See Carrara, Poes. Past.

Greek, The Anthology, as selected for the Use of Westminster, Eton and Other public schools: Also Edwards' Selection. London, 
I889. In this volume are fisher epigrams by Agathias, Alcaeus, Leonidas of Tarentum, Maecius Quintus, Paulus Silentuarius (Privy Counselor), The Prefect of Egypt, Sappho, and Serapion of Alexandria.

Greg, W. W. Pastoral Poetry and Pastoral Drama. London, 1906.

Grilli, L. Le Ecloghe Pecherecce di Jacopo Sannazaro e altre poesie Latine dei Secoli is e I6 recate in versi italiani. Lpi, 1899 .

Grotius, Hugo. See J. Rooke, Select Translations. Also, Poemata omnia. London, I645. Guardian, The. No.28. Monday, April I3, I7I3 (Steele).

Hanford, J. H. The Pastoral Elegy and Milton's Lycidas. Modern Language Ass'n of Am. Sept., r9ro.

Hardie, Alexandre. Alcée. Paris, i624.

Hedyle, Hedylus. Fragments. See Athenaeus. Herondas. Verse translation. Hugo Sharpley. London, 1906.

Hesion. The Shield of Heracles. Translation

by C. A. Elton. London, 1832 .

Homer. Iliad and Odyssey.

Jacobi, VAnieri. Praedium Rusticum. Tolossae,

I730, 42, Paris, 1746. Amsterdam, I749, 50, 65,80 .

Johnson, Dr. Samuel. Rambler, no. 36. Sat., July 2I, I750.

Jonson, Ben. Neptune's Triumph. London, I624. The Fortunate Isles. London, I626. Juliana Berners, 1496. The Treatyse of Fysshinge with an angle. 
Keats, John. Endymion. London, I8I8.

King, William. The Fisherman. London, 1700.

Lamartine, A. M. Graziella. Paris, I843.

Lammennais, H. Une Voix de Prison. Oeuvres.

Paris, I844.

Lathy, Thomas Pike. The Angler. London, I8I9.

Leech, Јонn. Musae Priores. London, I620. Lewis, Monk. The Castle Spectre. London,

I797.

Lucan. Pharsalia. Ed. with Eng. Notes by C.

E. Haskins. London, $\mathbf{1} 887$.

Lucian. Dialogues of the Sea Gods. The

Fisher. Tr. Howard Williams. London, I 888 .

LyLy, John. Galatea. London, I584? Love's Metamorphosis. London, 1588.

Mantuanus (Baptista Spagnuoli). En habes

Lector Bucolicorum Autores XXXVIII.

Oporinus. Basel, 1546.

Mangani, Mario. Origine e svolgimento dell' egloga pescatoria italiana. Nicastro, Bevilacque, I902.

Manutius, Paulus. In Vita Sannazarii, all early eds.

Marchetri, A. Piscatory sonnet, Nice. See

Vita e Poesie, ed. Francisco Marchetti. Venice, I755.

Margaret of Navarre. L'histoire des Satyres et Nymphes de Diane. Paris, I543.

Marsan, Jules. La Pastorale Dramatique en

France a La Fin du 16 et au Commencement du I7 Siècle. Paris, 1905. 
Meli, Giovanni. Li Piscaturi. See Opere di Giovanni Meli. Palermo, I838.

Menander. Philemon, Menander and the lost Attic Comedy, with fragments translated. Warner's Lib. of the World's Best Lit., vol. 19.

Metastasio, Pietro. Ecloga Piscatoria. Notes to I784 ed. Walton's Compleat Angler. London.

Michen, Jean. Mystère de la Passion avec les additions et corrections de Maistre Jean Michel (Des apostres). Première journée, scene de L'évocation, an elaboration of Arnoul Gresban's Mystère de la Passion (ante I456), Paris, I878.

Milton, John. Paradise Regained. London, I666. Lycidas, I637.

Moschus. See Bion.

Munday, Anthony. Chrysanaleia, or The Golden Fishing. London, I6I6. See John Nichols' The Progresses of Queen Elizabeth and of King James. London, I823.

Nonnus. Dionysiaca. Greek \& French ed. by Le Comte de Marcellus. Paris, 1856.

Ongaro, Antonio. Alceo, favola pescatoria. Venice, I58I, I582.

OpPIAN. Halieuticon. See also a Latin version, Cynegetica et Halieutica . . emendavit J. G. Schneider, accedunt versiones Latinae metricae. Lipsiae, I8r3.

Ovid. Metamorphoses. Halieutia ed. M. Haupt. Leipsig, I 838 .

Pancrates the Arcadian. Fragments. See Athenaeus. 
Parini, Giuseppe. Poesie. Firenze, i889.

Philostratus the Rhetorician. Imagines

Heroicae. Venice, 1550.

Plautus. Rudens. Ed. by E. A. Sonnenschein. Oxford, I89I.

Pomponius Bononiens. See Otto Ribbeck, Reliq.

Pontano, Giovanni. Carmina. Firenze, 1902. Pope, Alexander. Tatler, 1704. Discourse on the Pastoral.

Romances, The Greek, of Heliodorus, Longus and Achilles Tatius. Translated by Rev. Rowland Smith. London, I90I. For Xenophon's Ephesian History see A. H. Smith's Shakespeare's Pericles and Apollonius of Tyre.

Rohde, Erwin. Der griechische Roman. Leipsig, 1876. Works, ed. A. D. Devenish. London, 1756.

Rooke, M. Select translations from the works of Sannazarius, Grotius, Amaltheus (Bapt.) Heinsius, Buchanan, M. Hier. Vida. London, 1726.

Rota, Berardino. Egloghe Pescatorie. Naples, 1560. Third edition, 1572 .

Rowe, Nicholas. The Story of Glaucus and Scylla. See works, ed. A. D. Devenish, London, 1756 .

Rudiman, W. A. A Collection of Scarce, Curious and Valuable Pieces. Edinburgh, I773. Ruffino, Baptista (Giovanni). Favola Pescatoria. Venice, I6r2. 
Saint-Amant. Moyse Sauvé. Paris, 1653. See Oeuvres Complètes, ed. C. J. Jivet. Sammartino, Matteo. Pescatoria et Egloghe. Venice, I540, I566.

Sannazaro, Giacopo. Opera. Naples, I526, and many later eds.

Scott, Dr. Thomas. The Anglers-Eight Dialogues in Verse. London, I758.

Scott, Sir Walter. The Antiquary. Edinburgh, I6I6.

Shakespeare, Wrlliam. Pericles. London, i607I608. The Tempest, I6Io-i6i

Sidney, Sir Philip. Arcadia. London, 1590.

Smith, A. H. Shakespeare's Pericles and Apollonius of Tyre. Philadelphia, I898.

Spenser, Edmund. The Shepheards Calender. London, 1579. The Faerie Queene. London, I590, I 596.

Sophron. Fragments. See Athenaeus.

Swift, Jonathan. Journal to Stella. A Diary of $1610-1611$.

Storck, Wilhelm. German translation of Camões, Luis de. Paderborn, I880.

Taigero, G. Antonio. Casal Monferrato's Academy of Argonauts publications. Circa 1547.

Tasso, Bernardo. Amori. Venice, 1534 .

Tasso, Torquato. Amyntas. Acted I573. So-

lerti ed. I90I.

Tate, N. The Piscatorie Eclogues of Sannazaro

Englished by Mr. Tate. London, I726.

Theocritus. See Bion.

Thomson, James. The Seasons. Oxford, 1757. 
Thomson, William. Hymn to May. Oxford, I 758 .

Tiraboschi, G. Storia Della Litterat. Ital. Milan, I822-26.

Torraca, Francesco. Gl' Imitatori Stranieri di Jacopo Sannazaro. Rome, I882.

Twine, Laurence. Patterne of Paineful Adventures. London, 1576.

Verdizotti, G. M. Eclogae Piscatoriae. Rome, I 566.

VIrGIL. Aeneid. Georgics. Bucolics.

Vida, M. Hieronymus. See Rooke. Complete poetical works. London, I732.

Walton, IzaAK. The Compleat Angler. London, 1653.

Webster and Rowley. The Thracian Wonder. London, I66I.

Whitney, John. The Genteel Recreation with A Dialogue between Piscator and Corydon. London, 1700 and 1823.

Wilkins, George. Pericles Prince of Tyre. London, 1608.

Xenophon, the Ephesian. Amours d'Abrocome et d'Anthia; histoire Ephesienne. Tr. J. B. Jourdan. Paris, I785.

Zanchius, Basilius. See complimentary verses in early eds. of Sannazaro.

Zarro, Juan. See Codax. 


\section{CHRONOLOGICAL LIST OF THE CHIEF ENGLISH PISCATORIES}

Giles Fletcher. Latin Eclogues, I 58-

Edmund Spenser. The Faerie Queene, 1595.

(First three books, 1579-1589.)

John LyLy. Love's Metamorphosis, I 588.

Phineas Fletcher. Latin Eclogues, ante r6io. William Shakespeare. Pericles, 1607. The Tempest, I6ro.

Phineas Fletcher. Piscatorie Eclogs, composed I6ı-1616, pub. I633. Sicelides, composed I6I5, pub. I63I.

Dennys, John. The Secrets of Angling, r6 6 . Laurence Twine. Patterne of Paineful Adventures, $\mathrm{I}_{5} \mathrm{I} 6$.

John Leech. Musae Priores, I620.

Mrchael Drayton. The Muses' Elyzium, i630. John Donne. The Bait, I633.

John Milton. Paradise Regained, 1666.

T. Ford. Piscatio, I692.

John Whitney. The Genteel Recreation with

a Dialogue between Piscator and Corydon, I700.

John Diaper. Nereides or Sea-Eclogues, I 7 I2. JoHn Gay. Rural Sports, I7r3.

J. Rooke. N. TATE. Translations of Sannazaro, I726.

Moses Browne. Angling Sports in nine Piscatory Eclogues, I729.

Wm. Thomson. Hymn to May, I758. 
Dr. Thomas Scotr. The Anglers-Eight Dialogues in Verse, 1758.

Lewis, Monk. The Castle Spectre. London, 1797.

Scott, Sir Walter. The Antiquary, i8i6. JoHn Keats. Endymion, i818. 


\section{INDEX}

Achilles Tatius, 36 .

Addison, Joseph, 163, 164 .

Aelfric, 195.

Aelian, 156, 180.

Aeschylus, 42.

Aesop, 9.

Agathias, 33 .

Alcaeus, 8.

Alciphron, 27-31, 143.

Alexander ab Alexandro, 156 , 157.

Alvarez, G., 156 .

Amaltheus, J., 66.

Anthology, The Greek, 34 .

Antiphanis, 13, 14, 15.

Apollonius of Tyre, 134, 135.

Archippus, 15.

Arion, 9, 84, 142, 143.

Ariosto, 64 .

Aristotle, 180.

Athenaeus, 4, 7, 13, I4, 15, $26,42$.

Ausonius, Decimus Magnus, $43,90$.

Bacon, Sir Francis, 168.

Bagno, Ferrante, 66.

Baldi, Bernardino, 74 .

Basilius Zanchius, 51 .

Beaumont and Fletcher, Ior.

Bell, Beaupré, 164 .

Belleau, Remy, 87-91.

Bernardino, S., 78 .

Bernardes, Diego, 84, 86, 108.

Bernardim Ribeiro, 81.

Bible, The, I12, 113, 151, 152.

Binet, Claude, 91.

Bion, 25, 167.

Biondi, Luigi, 68.

Bohn (Libraries), 36 .

Bonarelli, C. G. de, 92.

Boscán, Juan, 8r.

Bottazzo, G. I., 67.

Boyle, Robert, 180.

Brisset, Roland, 92.

Brizeus, A., 94.

Bronner, Xavier, 200.

Browne, Moses, 165-181, I84, $187,188,195$.

Browne, William, r32, 139, $150,166$.
Bryant, William Cullen, 6.

Buchanan, George, 165 .

Calderon de la Barca, 84, 86, I33.

Callimachus, 26.

Calmo, Andrea, 73.

Camoes, Louis de, $82,83,84$. $86,108$.

Campaux, Antoine, 95, 199.

Capaccio, G. C., 73.

Carmosina Bonifacia, 45, 46, $51,52,88$.

Cárrara, Enrico, 67, 68, 70.

Casal Monferrato, 66 .

Cervantes, M. de, $8 \mathrm{r}$.

Chalkhill, Joseph, $15 \mathrm{I}$.

Chaucer, Geoffrey, 96.

Cholmeley, R. J., 22.

Christophe de Gamon, 91 .

Cicero, 42, 172.

Claude le Villain, 92.

Codax, Martin, 82.

Congreve, Philip, 166.

Cotta, Giovanni, 65.

Daniel, Samuel, 132.

Dante, 45, 63 .

Davors, Joseph, $15 x$.

Decimus Laberius, $4 \mathrm{I}$.

Delille, Jacques, 95.

Dennys, John, 195.

Diaper, John, 155-165.

Diphilos, $15,39$.

Donne, John, 148, 150, 151 , $168,178$.

Drayton, Michael, 144-148, I50, I5I, 162, 184 .

Drummond, William, 102.

Dryden, John, 56, 153, 171 , 188.

Du Bartas, S., 151, 156, 180.

Du Bellay, J., 87.

Elton, C. A., 7 .

Emerson, O. F., 112.

Epicharmus, II, 12.

Erasmus, Desiderius, 64, 95 .

Fawkes, T., 8.

Fletcher, John, 136, 149, 166.

Fletcher, Giles the Elder, 96, 97, $101,126$. 
Fletcher, Giles the Younger, I I 0 .

Fletcher, Phineas, 97, 106, 107-139, 140, 141, 144, 145, $150,151,152,162,166,171$, $173,174,181,183,194,195$.

Fonteny, Jacques de, 95.

Ford, Simon, 152.

Franciscus Champion, 95.

Frondius, N., 95 .

Gambara, Lorenzo, 67.

Garcilaso de la Vega, 8r.

Gay, John, 187, 188, 189, I90, 191, 194.

Geoffrey of Monmouth, I73, 174.

Goethe, J. W., 200.

Goina (Goynaeus), 67.

Gordon, Patrick, 180.

Gower, John, 134.

Greban, Arnoul, 94.

Greene, Robert, 105.

Greg, W. W., 73, $139,144$.

Grotius, Hugo, 140, 142, 143 , $165,166$.

Guardian, The, 163, 164, I70, 182.

Guarini, G. B., 136.

Hanford, J. H., 48.

Hardie, Alexandre, 93.

Hedyle (also Hedylus), 26, 27.

Heinsius, Daniel, 142, 167.

Heliodorus, 36, 134 .

Herondas, $13,15$.

Hesiod, 6.

Homer, 4, 5, 6, 7, 19, 38, 107.

Horace, $152,156$.

Hulric de Hutten, 200.

Jacobi Vanieri, 95, 192.

Jodelle, E., 9r.

Johnson, Samuel, 172, 181, 182,183 .

Jonson, Ben, 101, 102, 195.

Juliana, Dame, 195.

Keats, John, 193.

King, William, 152.

Lamartine, A. M., 196-198.

Lamennais, F. R., 95.

Lang, A., 200.

Lathy, Thomas Pike, I86.

Leech, John, 140-144, I62, 163.

Leonidas of Tarentum, 23, 31 .

Lewis, Monk, 139.
Lillo, George, 134 .

Longus, 35 .

Lope de Vega, 81.

Lucan, 42.

Lucian, 31, 155, 156, 101.

I.yly, John, 101, 139.

Maecius Quintus, 32.

Mallory, Sir Thomas, 99.

Mangani, Mario, 199.

Mantuan, 67, 97, II5, 122.

Marchetti, A., 78.

Margaret of Navarre, 87.

Marlowe, Christopher, 148, I 54.

Marot, Clement, 91, 125.

Marsan, Jules, 93.

Martial, 176.

Martin, Giovanni, 87.

Meli, Giovanni, 87.

Menander, $15,16$.

Mendoza, Iñigo de, 8r.

Menéndez y Pelayo, M., 82.

Metastasio, Pietro, 186.

Michel, Jean, 94.

Milton, John, 48, 112, 114 , $117,151,170,173,174,175$, 176.

Montemôr, Jorge de, 81.

Moschus, 25, 26, 167, 200.

Munday, Anthony, roo.

Nashe, Thomas, 133.

Nichols, John, 99, I01, I 12.

Nonnus, 34.

Nowell, Dr. A., 172.

Olaus Magnus, 156.

Ongaro, Antonio, $72,77,86$, 92, 93 .

Oppian, 32.

Ovid, 27, 42, 138,180 .

Pancrates (The Arcadian), 10.

Parini, Giuseppe, 79, 80.

Paulus Manutius, 62.

Paulus Silentuarius, 33.

Pausanias, 42.

Pedro de Encinas, 42.

Peter, E. W., 8.

Petrarch, 63.

Philostratus, 25.

Plato, 13.

Plautus, 15, 39, 40.

Pliny, 32, 44, 176.

Plutarch, 42.

Pollux, 16. 
Pomponius Bononiens, 4I.

Pontano, 45, 46, 51, 53, 56, $57,59$.

Pope, Alexander, 153, 157 , I71, 172, 183, 187, 188, 190.

Prefect, The, of Egypt, 32.

Rambler, The, 181, 183.

Rhannusius, 156.

Rohde, Erwin, 134 .

Ronsard, Pierre de, 91, 92.

Rooke, M., I64, $165,172$.

Rota, Berardino, 70, 71, 72, 79.

Rowe, Nicholas, 152.

Ruddiman, W. A., $x 86$.

Ruffino, Baptista (Giovanni), 78.

Sabie, Francis, ro5.

Saint-Amant, 94.

Sammartino, Matteo, 73.

Sannazaro, Giacopo, 4, 5, 27, $43,44,45-65,66,67,68$, $69,70,71,72,73,74,75$, $77,78,79,80,81,82,83$, $84,86,87,88,89,90,91$, $92,96,97$, хог, 107, r08, 109, I I I, I I4, I 28, 129, I 35 , $140,141,142,143,144,147$, $154,155,157,158,159,162$, $163,164,165,166,167,170$, $176,177,179,180,182,183$, $185,186,187,196,199$.

Sappho, 8, 28.

Scaliger, Julius, 52.

Schiller, 200.

Scott, Dr. Thomas, 184, 185 , 186.

Scott, Sir Walter, 195.

Seneca, 40.

Serapion, 33 .

Servius, ro7.

Shakespeare, William, 133, I 44 .

Sidnam, Jonathan, 92.

Sidney, Sir Philip, 133, 199.

Smyth, A. H., I 34 .

Solerti, Angelo, 78.

Spenser, Edmund, 74, 102, 103, 105, 106, 107, 108, 109, $111,114,115,116,117,118$, $120,122,123,124,125,126$, $127,128,130,132,139,144$,
I52, I 53, I 59, 166, I67, I7 1, I74, I75, I77, I83, 194.

Sophron, 12, 13.

Steele, Richard, 153.

Strabo, 42.

Storck, Wilhelm, 84.

Swift, Jonathan, I 55.

Taigeto, G. A., 67 .

Tasso, Bernardo, 68, 69, 70, 167 .

Tasso, Torquato, 72, 76, 77, $78,93,16 \%$.

Tate, N., 164 .

Tatler, The, 153.

Theocritus, $3,7,8,17,18,22$, $23,24,25,26,27,28,29$, 3о, 31, 38, 39, 40, 43, 47, $48,49,52,54,55,59,60$, $63,64,68,69,75,80,87$, 89 , 91, 92, IOI, II4, 137, $141,153,158,162,166,167$, $168,174,179,182,187,193$, I94, 200 .

Thomson, James, I90, 191.

Thomson, William, 183.

Tiraboschi, G., 70.

Torraca, Francesco, 199.

Twine, Laurence, I34.

Verdizotti, G. M., 67 .

Virgil, 4, 3I, 39, 4I, 44, 47, $48,49,50,51,52,53,55$, $56,57,58,59,61,62,63$, $64,68,69,71,80,82,87$, 90-97, 107, 109, II1, 114, $127,132,140,153,154,157$, $161,163,164,166,167,168$, $172,173,176,177,187,188$, 190.

Vida, M. H., 66.

Vulpius, $51,52$.

Walton, Izaak, 43, III, II2, $150,151,153,154,168,170$, $172,174,175,176,177,180$, I81, I84, 185, I86, 189.

Webster and Rowley, 139.

Whitney, John, I 53, I 54, I55, $169,184,185,187$.

Wilkins, George, 134 .

Wotton, Sir Henry, 151, 68. Xenophon, The Ephesian, 134. Zarro, Juan, 82. 


\section{THE COLUMBIA UNIVERSITY PRESS}

Columbia University in the City of New York

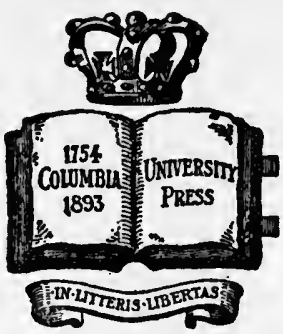

The Press was incorporated June 8, 1893, to promote the publication of the results of original research. It is a private corporation, related directly to Columbis Unlversity by the provisions that Its Trustees shall be officers of the University and that the President of Columbia University sahll be President of the Press.

The publications of the Columbia University Press in, clude works on Biography, History, Economles, EducationPhilosophy, Linguistics, and Literature, and the following series :

Columbia University Anthropological Series. Columbia University Biological Series.

Columbia University Studies in Classical Philology. Columbia University Studies in Comparative Literature.

Columbia University Studies in English.

Columbia University Geological Series.

Columbia University Germanic Studies.

Columbia University Indo-Iranian Series.

Columbia University Contributions to Oriental History and Philology.

Columb ia University Oriental Studies.

Columb $\mathrm{i}_{\mathrm{a}}$ University Studies in RomancePhilology and Literature.

Blumenthal Lectures.

Carpentier Lectures.

Julius Beer Lectures.

Hewitt Lectures. Jesup Lectures.

Catalogues will be sent free on application

LEMCKE \& BUECHNER, Agents 30-32 West 27th St.

New York 


\section{STUDIES IN ENGLISH}

Joseph Glanvill. By Ferris Greenslet, Ph.D. Cloth, 12mo, pp. xi +235 . $\$ 1.50$ net.

The Elizabethan Lyric. By John Erskine, Ph.D. Cloth, 12mo, pp. xvi + 344. $\$ 1.50$ net.

Classical Echoes in Tennyson. By Wilfred P. Mustard, Ph.D. Cloth, $12 \mathrm{mo}$, pp. xvi +164 . $\$ 1.25$ net.

Sir Walter Scott as a Critic of Literature. By Margaret Ball, Ph.D. Paper, $8 \nabla 0$, pp. $x+188 . \$ 1.00$ net.

The Eariy American Novel. By Lillie Deming Loshe, Ph.D. Paper, 8vo, pp. vii +131 . $\$ 1.00$ net.

Studies in New England Transcendentalism. By Harold CGoddard, Ph.D. Paper, 8vo, pp. $x+217$. $\$ 1.00$ net.

A Study of Shelley's Drama "The Cencl." By Ernest Butherland Bates, Ph.D. Paper, 8vo, pp. ix + 103. $\$ 1.00$ net.

Verse Satire in England Before the Renaissance. By Samuel Marion Tucker, Ph.D. Paper, 8vo, pp. $x i+245$. $\$ 1.00$ net.

The Accusative with Infinitive and some Kindred Constructions in Engilsh. By Jacob Zeitlin, Ph.D. Paper, 8vo, pp. viii $+177 . \$ 1.00$ net.

Government Regulation of the Elizabethan Drama. By Virginia Crocheron Gildersleeve, Ph.D. Cloth, 8vo, pp. vil +259. $\$ 1.25$ net.

The Stage History of Shakespeare's Ring Richard the Third. By Alice I. Perry Wood, Ph.D. Cloth, 8vo, pp. xi + 186. \$1.25 net.

The Shaksperian Stage. By Victor E. Albright, Ph.D. Cloth, 8 vo, pp. xil +194 . $\$ 1.50$ net.

Thomas Carlyle as a Critic of Literature. By Frederick W. Roe, Ph.D. Cloth, 8ro, pp. xi +152 . \$1.25 net.

The Authorshtp of Timon of Athens. By Ernest Hunter Wright, Ph.D. Cloth, 8vo, pp. $1 x+104$. \$1.25 net.

English Tragicomedy, Its Origin and History. By Frank H. Ristine, Ph.D. Cloth, $8 \mathrm{vo}$, pp. $x \nabla+247 . \$ 1.50$ net.

Leigh Hunt's Relations with Byron, shelley and Keats. By Barnette Miller, Ph.D. $8 \mathrm{vo}$, cloth, pp. vii +169 . \$1.25 net.

The Rise of the Novel of Manners. By Charlotte E. Morgan, Ph.D. 8vo, cloth, pp. ix +271 . Price, $\$ 1.50$ net.

John Dennis. His Iife and Criticism. By Harry G. Paul, Ph.D. 8vo, cloth, pp. viii +229 . Price, $\$ 1.25$ net.

\section{Lemcke \& Buechner, Agents}


New Poems by James I. of England. By Allan F. Westcott, Ph.D. 8vo, cloth, pp. xci +121 . Price, $\$ 1.50$ net.

The Middle English Penitential Lyric. By Frank Allen Patterson, $\mathrm{Ph}$ D. 8 ro, eloth, pp. $1 x+203$. Price, $\$ 1.50$ net.

The Exemplum in the Early Religlous and Didactic Literature of England. By Joseph Albert Mosher, Ph.D. 8vo, cloth, pp. $\mathrm{xi}+150$. Price, $\$ 1.25$ net.

The Sollloquies of Shakespeare. By Morris LeRoy Arnold, Ph.D. 8vo, cloth, pp. $x+177$. Price, $\$ 1.25$ net.

The Political Prophecy in England. By Rupert Taylor, Ph.D. 8vo, cloth, pp. $\mathrm{xx}+165$. Price, $\$ 1.25$ net.

Mathew Carey. Editor, Author and Publisher. By Earl $L$. Bradsher, Ph.D. 8vo, cloth, pp. $x i+144$. Price, $\$ 1.25$ net.

Thomas Dekker. A study. By Mary Leland Hunt, Ph.D. 8vo, cloth, pp. xiil + 212. Price, \$1.25 net.

\section{STUDIES IN COMPARATIVE LITERATURE}

Romances of Roguery. By Frank Wadleigh Chandler, Ph.D. Part I. The Picaresque Novel in Spain. 12mo, cloth, pp. Ix +483 . Price, $\$ 2.00$ net.

A History of Literary Criticism in the Renalssance. By Joel Elias Spingarn, Ph.D. Second edition, revised and augmented. $12 \mathrm{mo}$, cloth, pp. $x 1+330$. Price, $\$ 1.50$ net.

Platonism in English Poetry of the Sixteenth and Seventeenth Centuries. By John Smith Harrison, Ph.D. 12mo, cloth, pp. $\mathrm{xI}+235$. Price, $\$ 2.00$ net.

Irish Life in Irish Flction. By Horatio Sheafe Krans, Ph.D. $12 \mathrm{mo}$, cloth, pp. vii +338 Price, $\$ 1.50$ net.

The English Heroic Play. By Lewis Nathaniel Chase, Ph.D. 12mo, cloth, pp. xii +250 . Price, $\$ 2.00$ net.

The Orfental Tale in England in the Eighteenth Century. By Martha P1ke Conant, Ph.D. 12mo, cloth, pp. xxvi + 312. Price $\$ 2.00$ net.

The French Influence in English Literature. By Alfred Horatio Upham, Ph.D. 12mo, cloth, pp. ix +560 . Price, $\$ 2.00$ net.

The Influence of Moliere on Restoration Comedy. By Dudley H. Miles, Ph.D. 12mo, cloth, pp. $x i+272$. Price, $\$ 1.50$ net.

The Greek Romances in Elizabethan Prose Fiction. By Samuel Lee Wolff, Ph.D. 12mo, cloth, pp. vii + 529. Price, $\$ 2.00$ net.

The Idylls of Fishermen. By Henry Marion Hall, Ph.D. 12mo, cloth, pp. ix +216 . Price $\$ 1.50$ net.

\section{Lemcke \& Buechner, Agents}





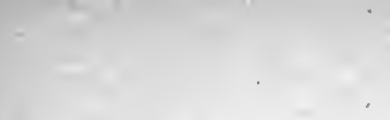

$-$ 



$$
9908
$$


University of California

SOUTHERN REGIONAL LIBRARY FACILITY

305 De Nave Drive - Parking Lot 17 - Box 951388 LOS ANGELES, CALIFORNIA 90095-1388

Return this material to the library from which it was borrowed.

OCT । 02005 


\section{8}

UC SOUTHERN REGIONAL LIBRARY FACILITY

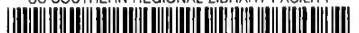

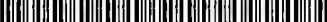

A $000676824 \quad 6$ 
Un 